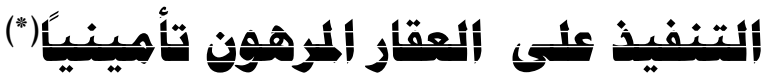

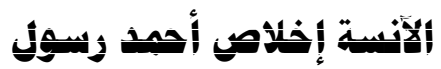

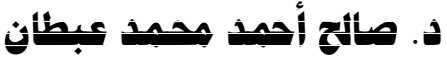

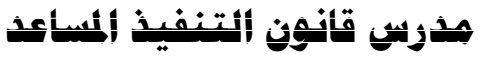

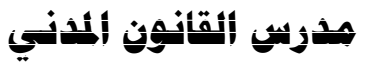 \\ كية |لحقهق / جأمهة ألهصأ \\ كية ألمقهق / جأمهة ألنهوئ}

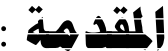

للتنعريف بالموضوع و واعطاء مقدمة و افيـة عنـه ارتأينـا تقسيم المقدمـة وفقاً

للنقاط الاتية:

اولاً : سبب الاتية: اختيار الموضوع :

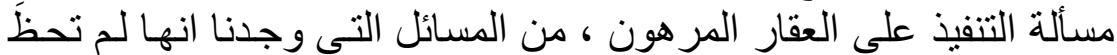

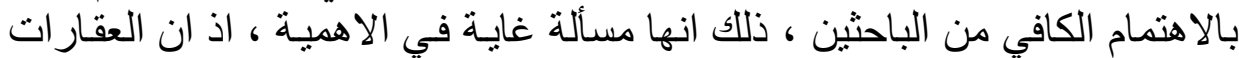

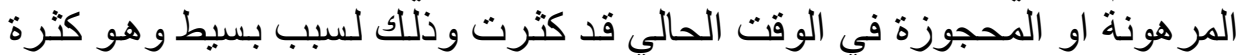

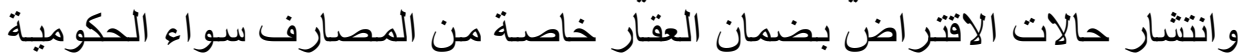

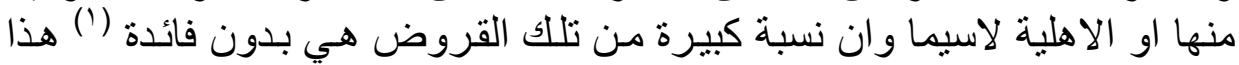

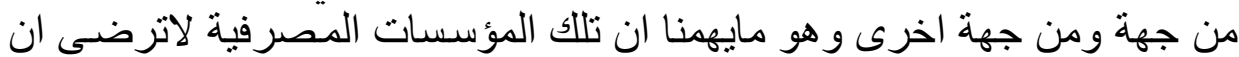

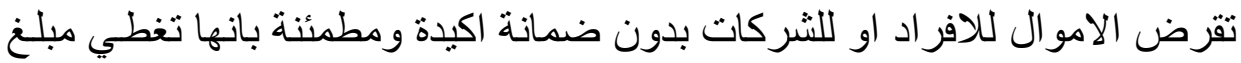

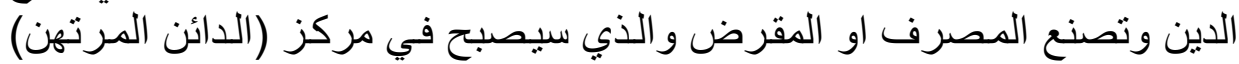

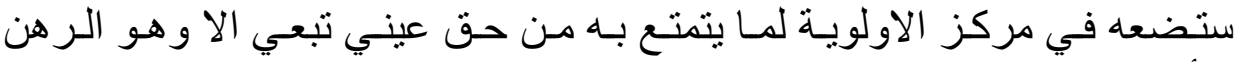
التأمبني. ثنانياً : هدف البحث : جاء البحث للاجبابة عن التساؤ لات الات الاتية:

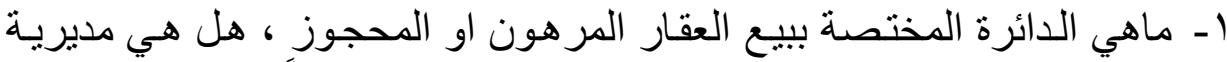

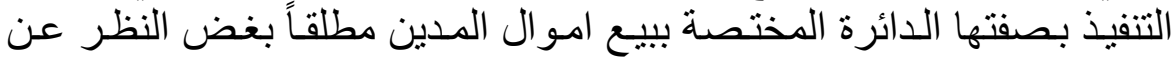

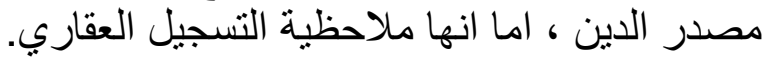

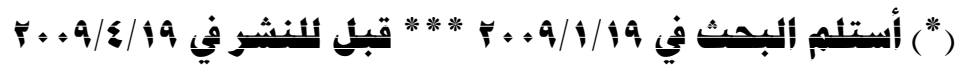

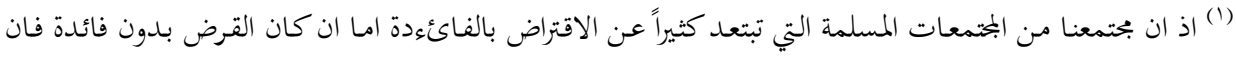
اغلب افراد البحتمع سيحاولون الحصول عليه. 
r- ثم ماهي الاجر اءات المتبعة في البيع ، هل هي الواردة في قانون التسجيل العقاري ، ام الواردة في قانون التئن التنفيذ.

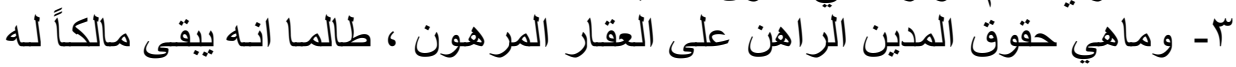

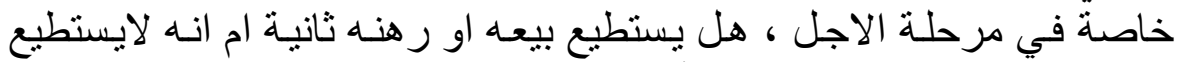

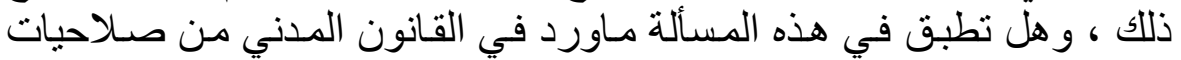

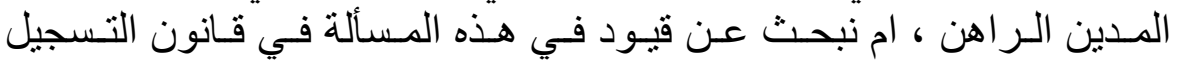

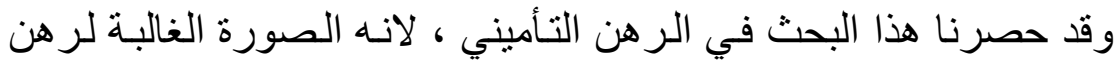

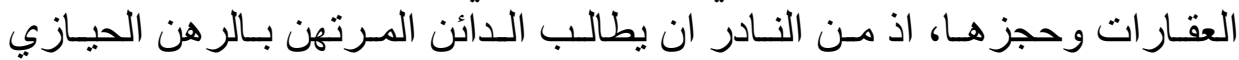

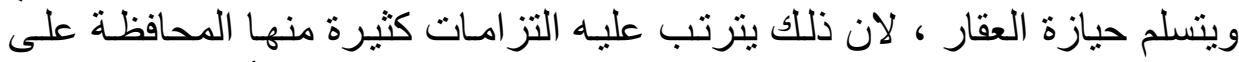

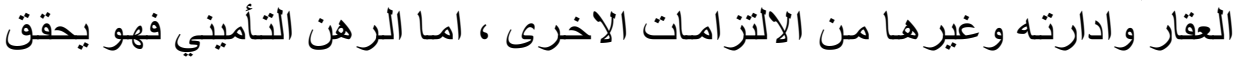

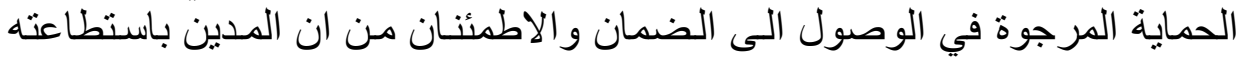

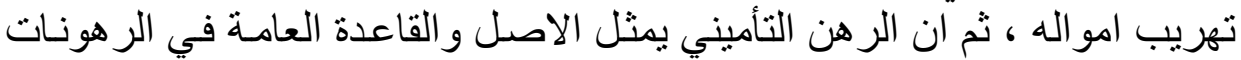

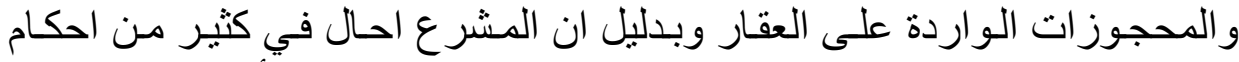

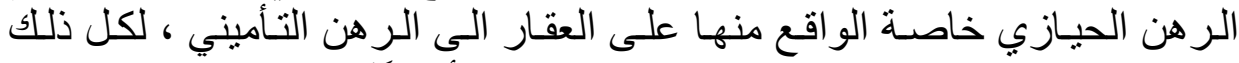
حصرنا هذا البحث في التتفيذ على العقار المر هون تأمينياًَ دون الحيازي.

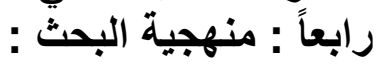

اعتمدنا في بحثنا هذا على المنهج التحليلي التطبيقي ، معنى ذلك انتسا

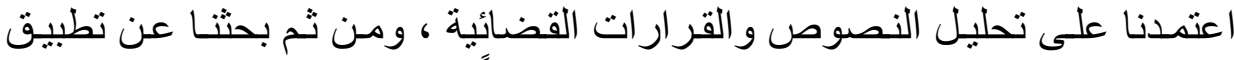
مفردات البحث في قرارات القضاء العر اقي تحديداً.

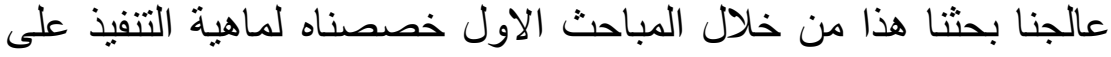

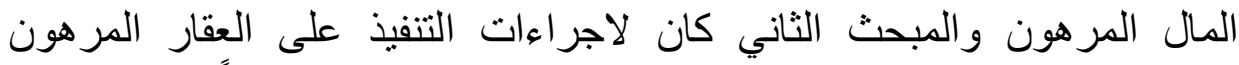
و البحث الثالث لاثار التنفيذ على العقار المرهون وملحقاته ، واخيراً كانت الخاتمة التهان

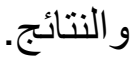

\section{أنبحث الاهول}

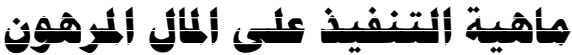




\section{jexil init}

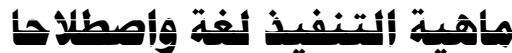

التنفيذ: هو تحقيق الشيء واخر اجه من نطـاق الفكر والتصور الى مجال العمل

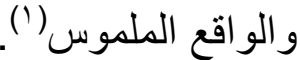

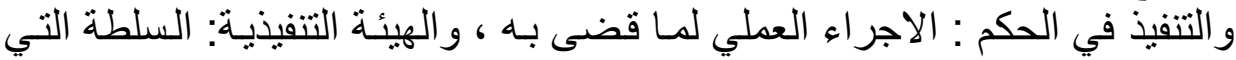

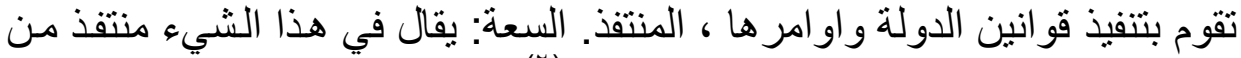

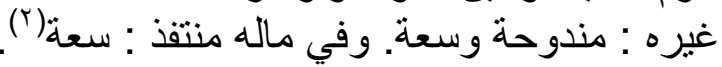
|

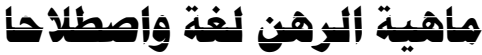

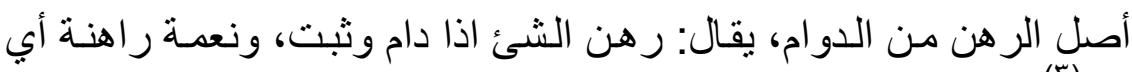

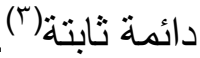

ومعنى الرهن؛ ( احتباس العين وثيقة بـالحق ليستوفى الحق من ثمنها أو

من ثمن منافعها).

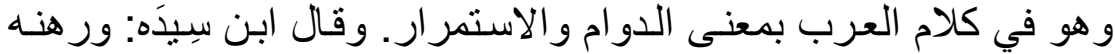

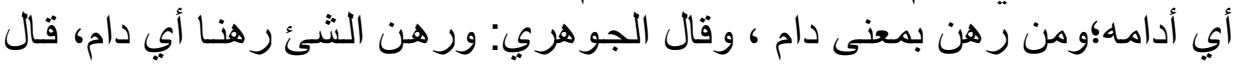

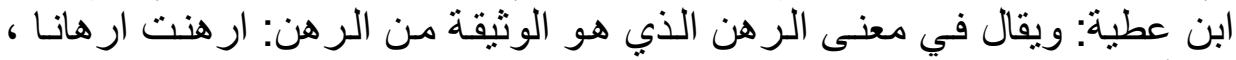

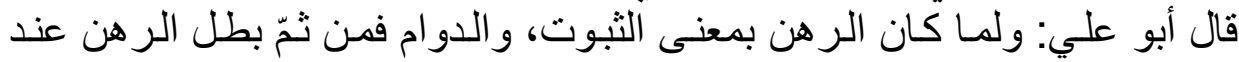

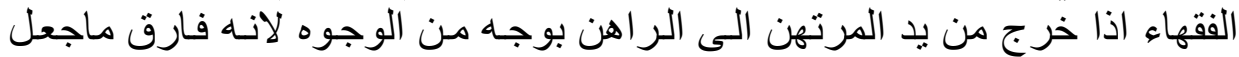
باختيار المرتهن له أله

(1) مشار اليه لدى كل من : د. عزمي عبد الفتاح ، قواعد التنفيذ الجبري في قانون المرافعات ، المطبعة العربية الحديثة ،

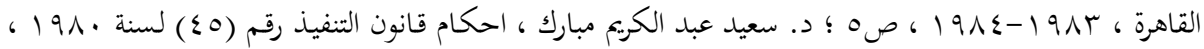

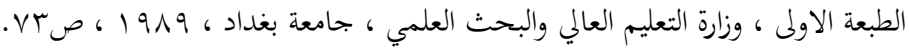

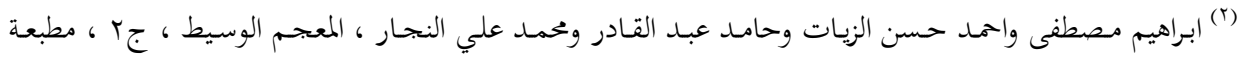

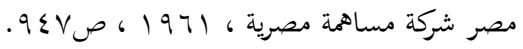

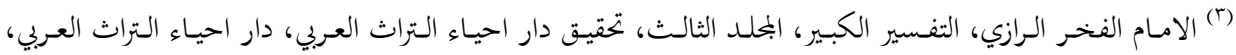

$$
\text { بيروت- لبنان، بلاسنة طبع،ص . . 1. }
$$




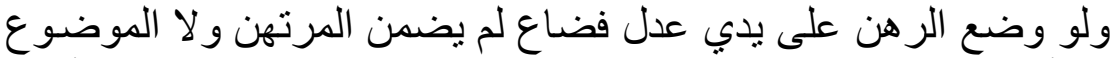

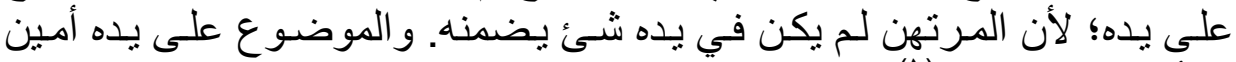

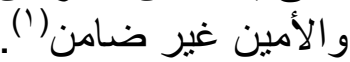

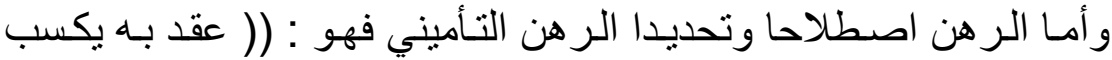

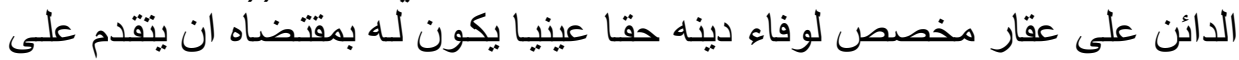

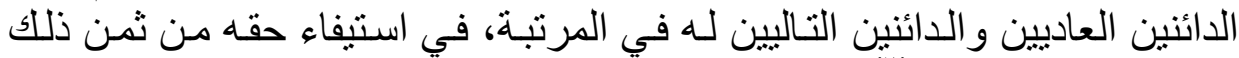

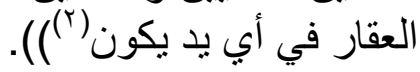

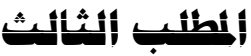

\section{هبدأ تحصيص الثرفين}

معنى هذا المبدأ ضرورة تعيين وتحديد الرهن من حيث العقار المرهون

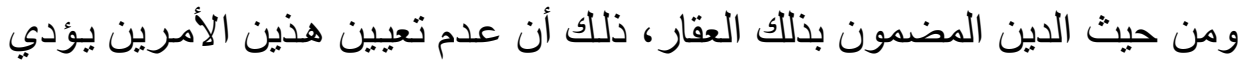

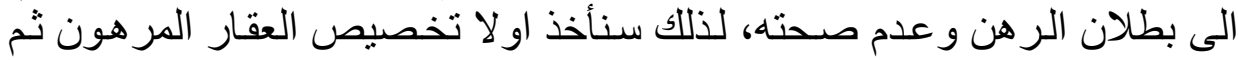

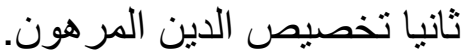

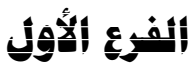

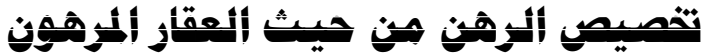

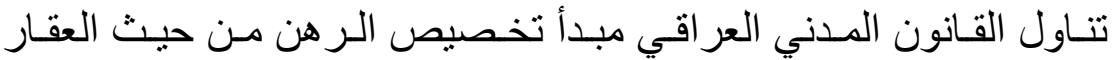

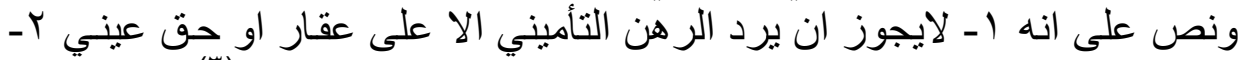

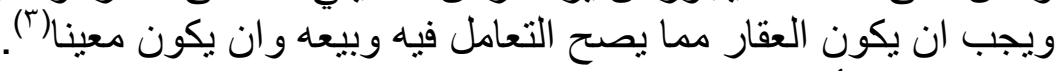

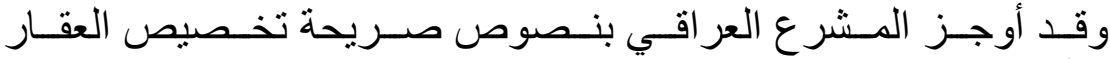

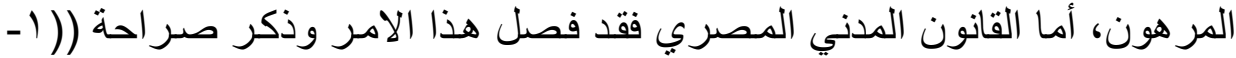

(1) ابي عبد الله محمد بن احمد الانصاري القرطبي، الجحامع لاحكام القران، طا تحقيق مصطفى البدري، البحلد الثاني،

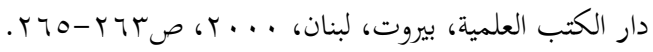

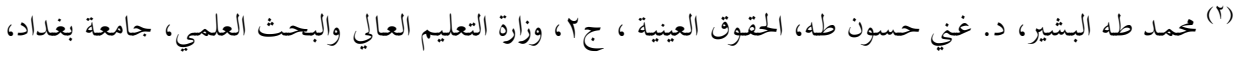

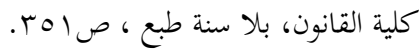

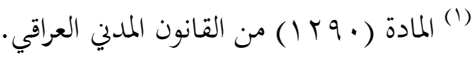




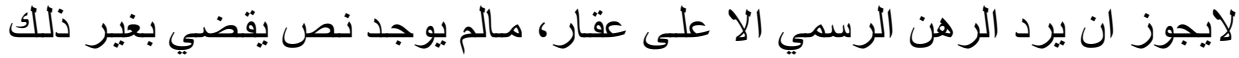

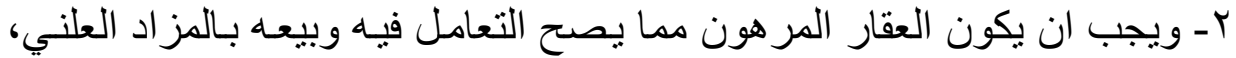

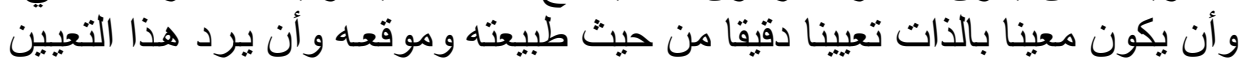

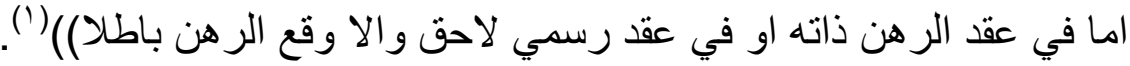

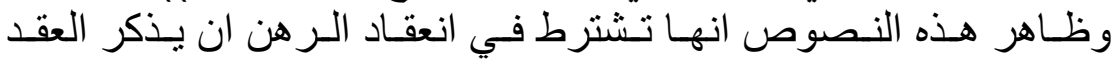

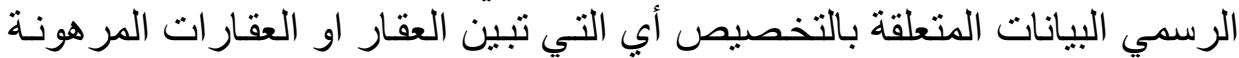

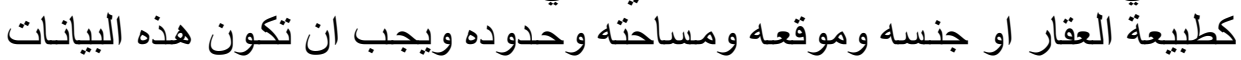

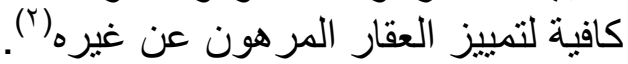

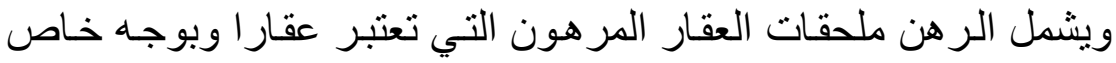

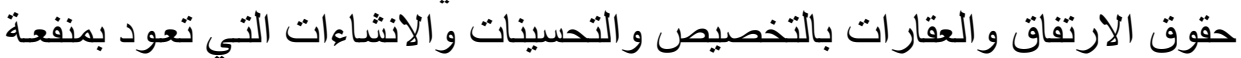

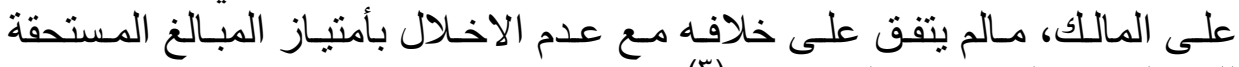
للمقاولين او المهندسين المعماريين(").

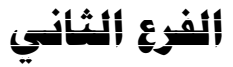

\section{تقصيص ألدين أiضمهرن}

الدين المضمون بالرهن يمثل ركن السبب في الرهن التأميني، بمعنى ان

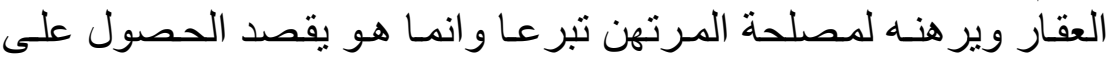

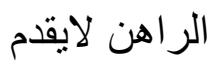

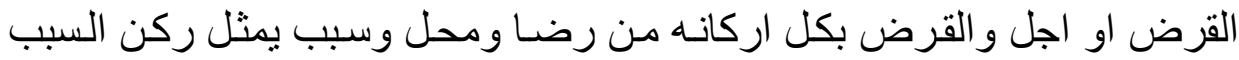

$$
\text { في الرهن التأميني وكما في الثكل ألآتي :- }
$$

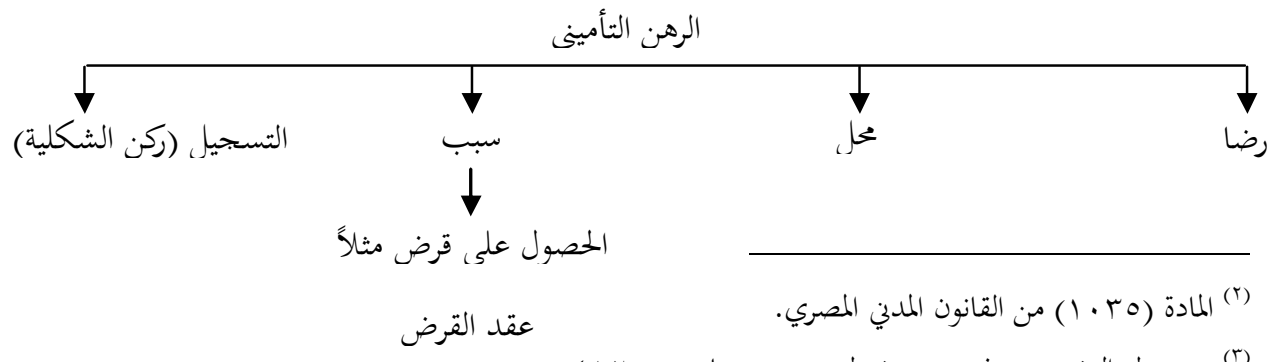

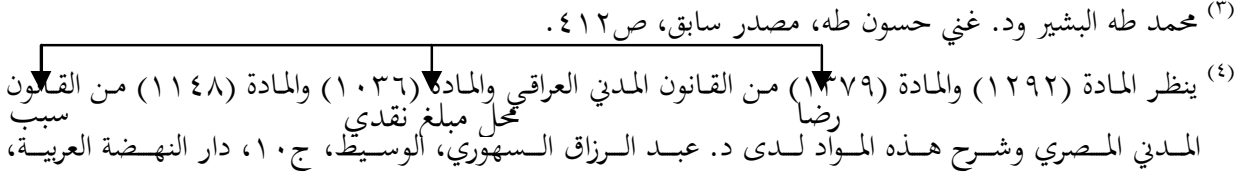

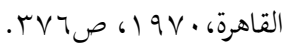




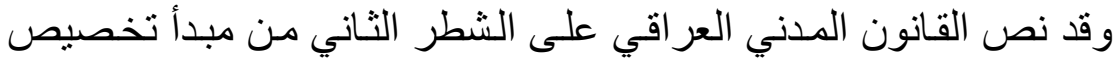

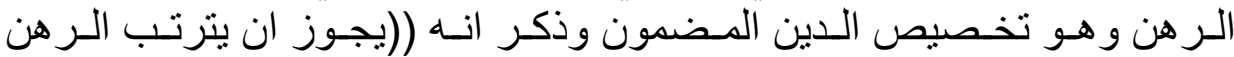

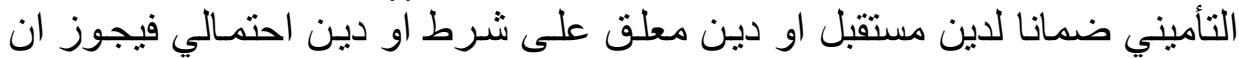

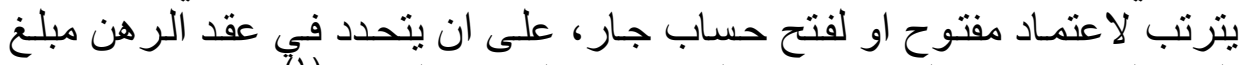

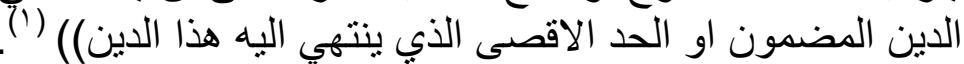

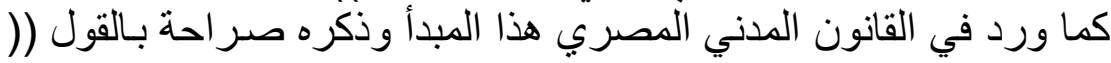

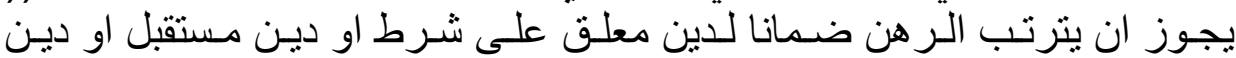

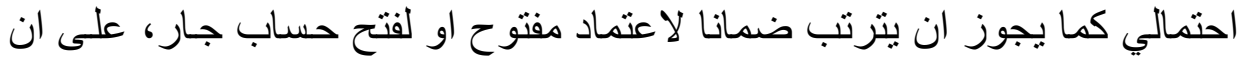

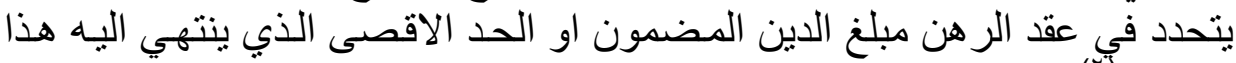
(الدين) (r) (ب)

و عليه يجب ان يكون الدين المضمون موجودا او لا او قابلا للوجود و لا الا

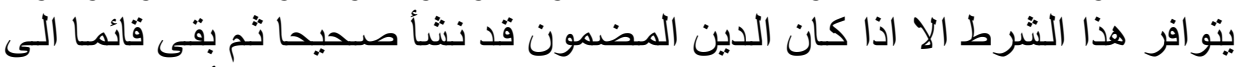

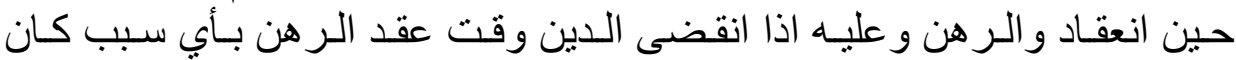

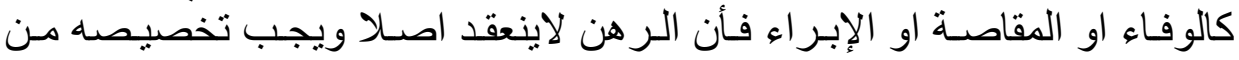

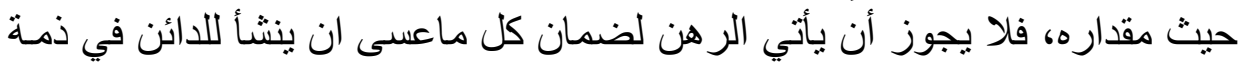

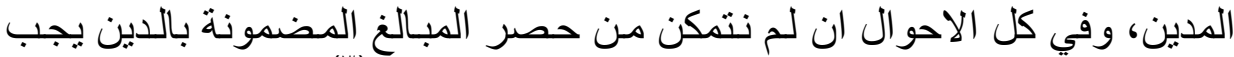

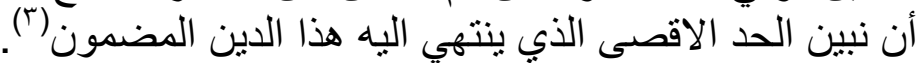

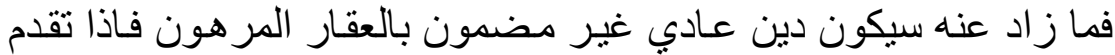

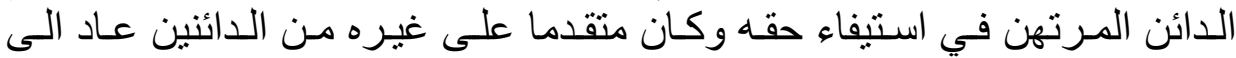

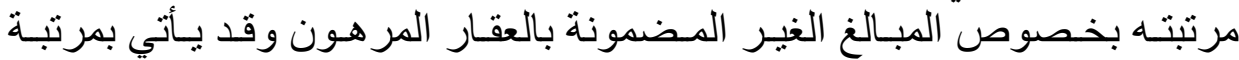

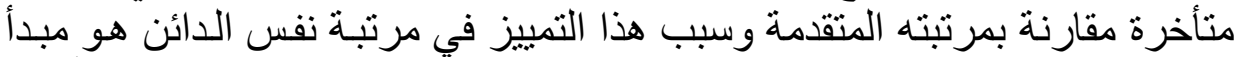

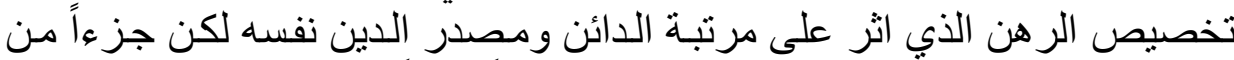

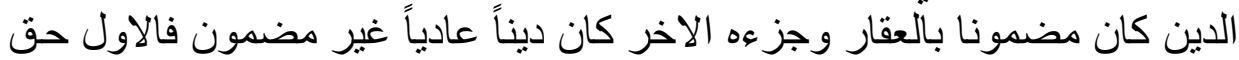
عيني و الثاني حق شخصي.

$$
\begin{aligned}
& \text { (1) (1) (لمادة (ra r 1 ) من القانون المدني العراقي. }
\end{aligned}
$$

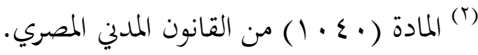

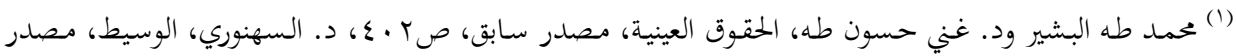




\section{أنبمث أنثاني}

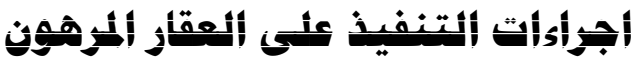

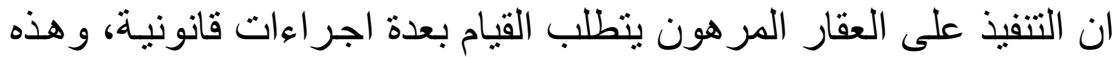

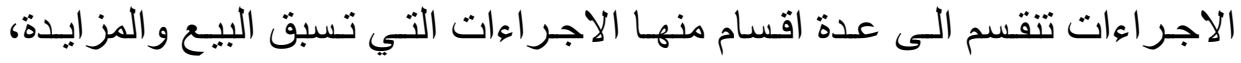

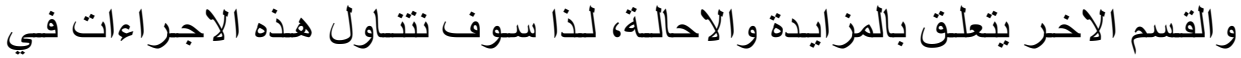

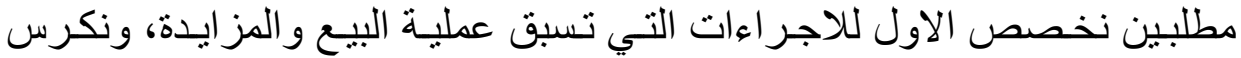

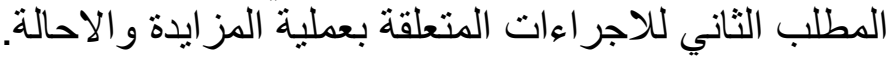

\section{joxit initi}

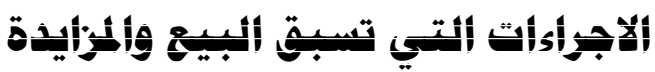

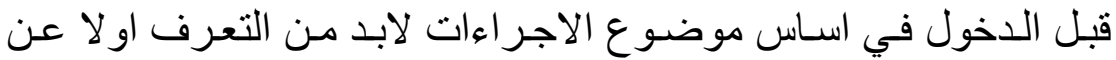

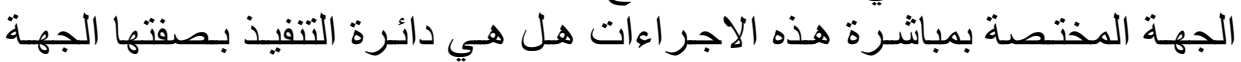

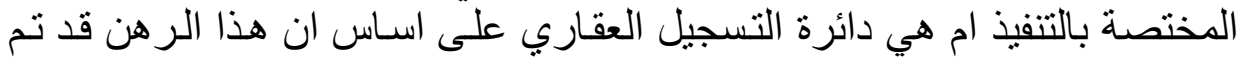
تسجيله فيها؟

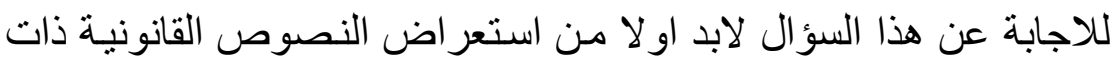
العلاقة في قانون التنفيذ وفي قانون التذان التسجيل العقاري.

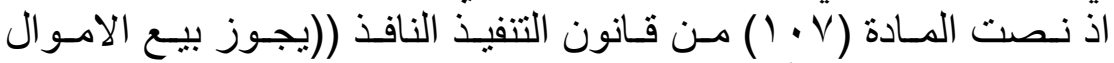

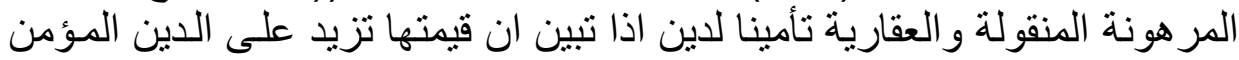

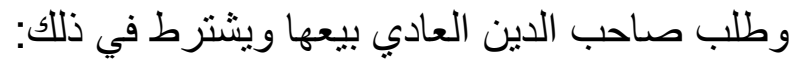

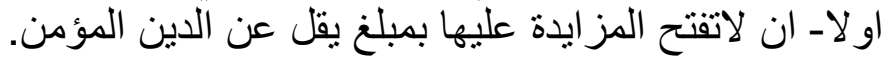

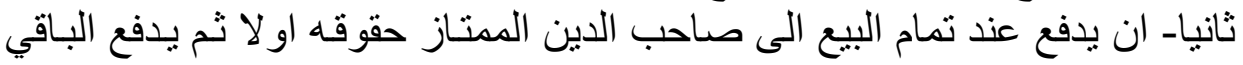
الى صاحب الدين العادي)).

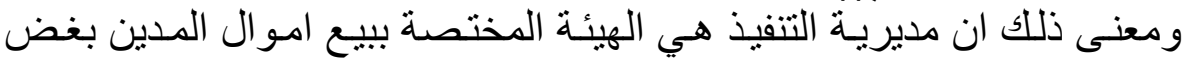

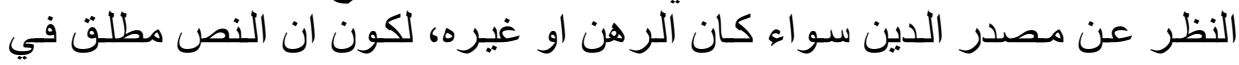

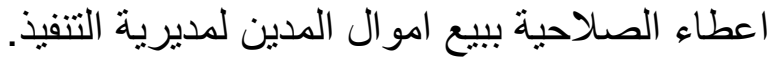

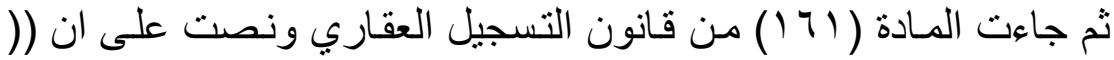

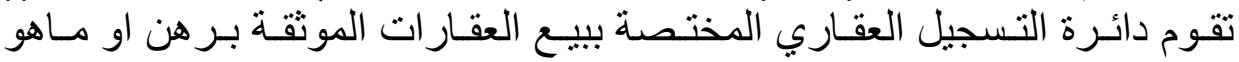

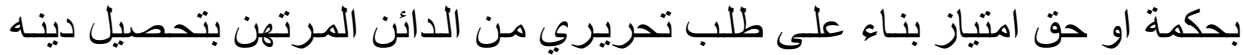

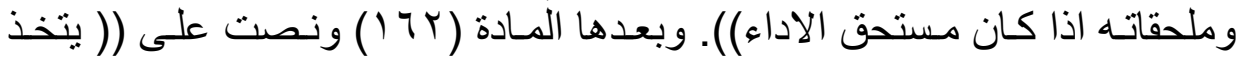




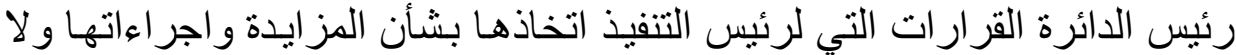

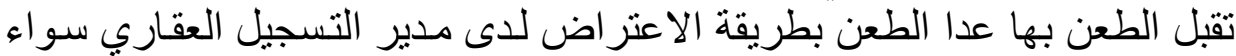

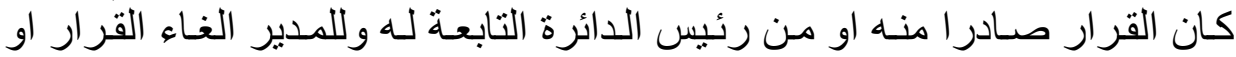

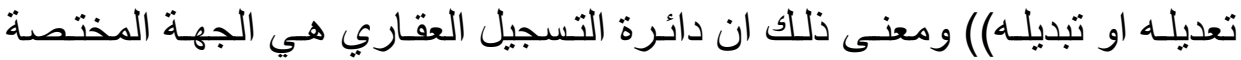

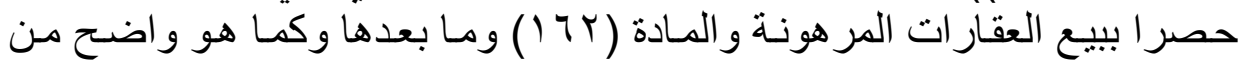

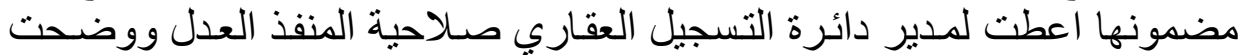
كيفية الطعن في قرار اتهـ

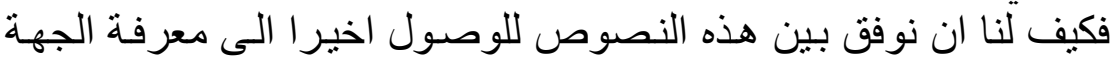

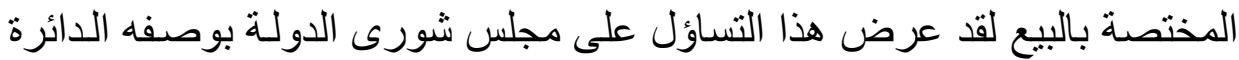

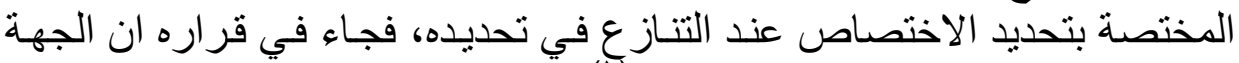

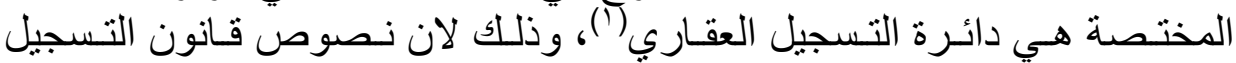

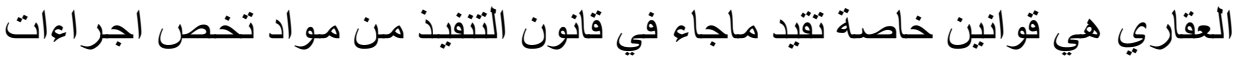

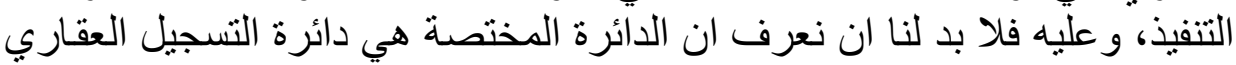
وليست دائرة التنفيذ.

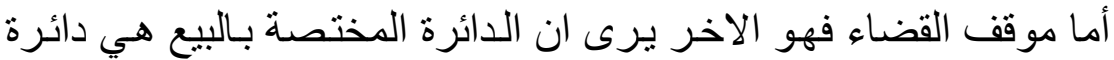

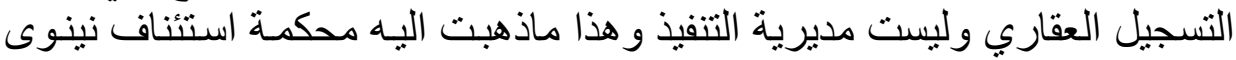

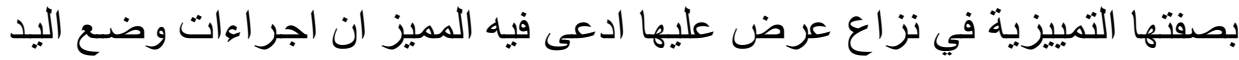

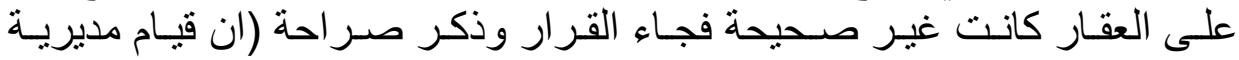

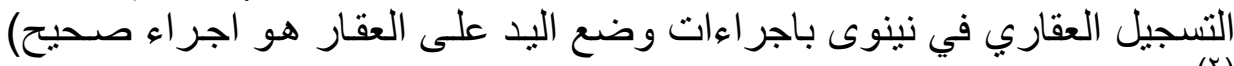

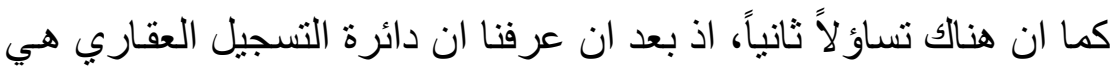

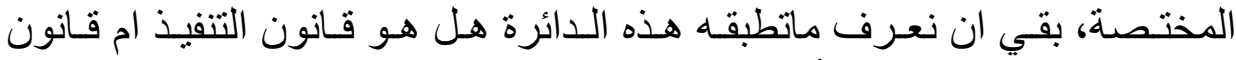

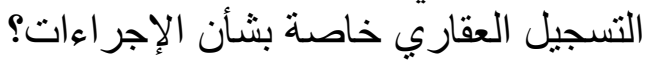

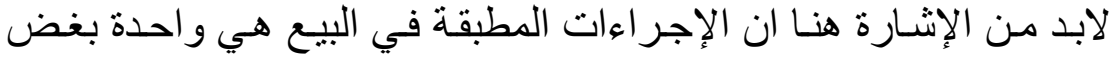

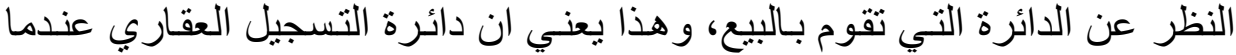

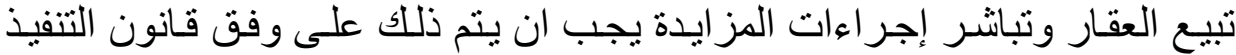
وقانون المر افعات، ولكن قبل ذلك ان كانت هناك قو اعد اعدة خاصة في قانون التسجيل

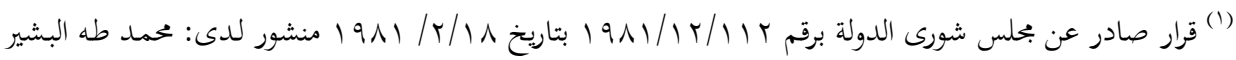

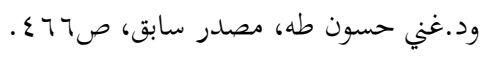

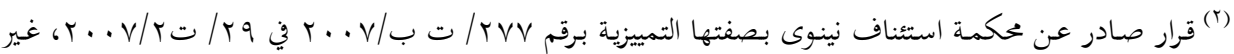




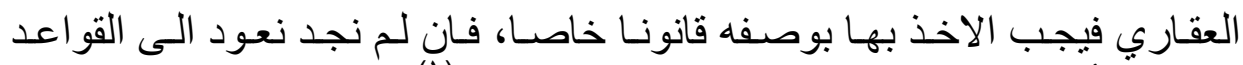

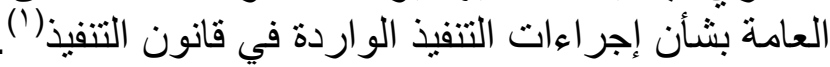
وتتلخص الإجراءات التي تسبق عملية البيع و المز ايدة بما يلئي:-

اولا- تقديم طلب البيع:

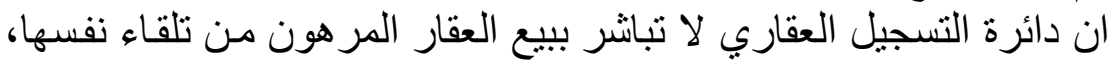

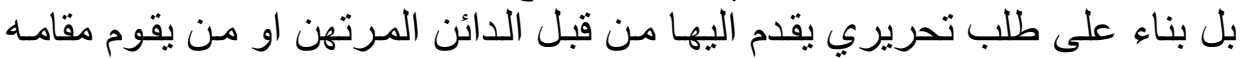

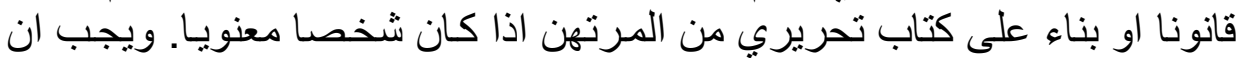

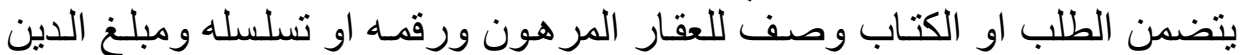

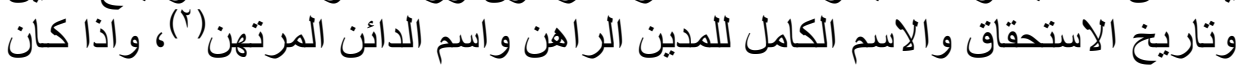

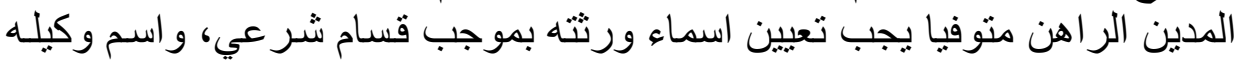

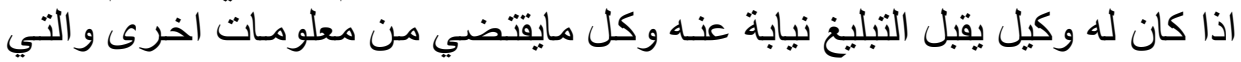

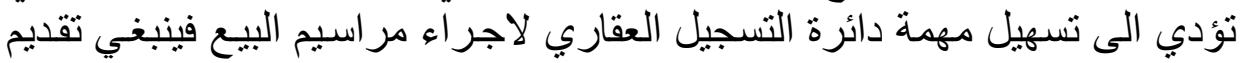

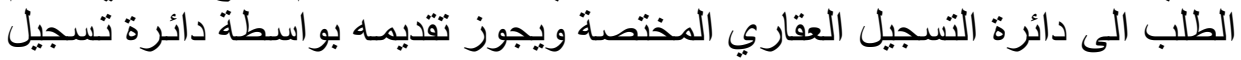

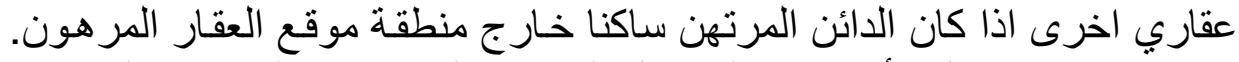

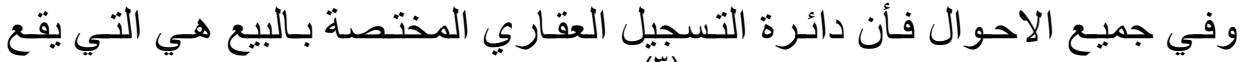

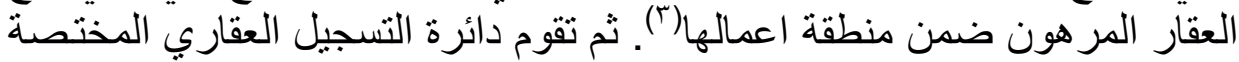

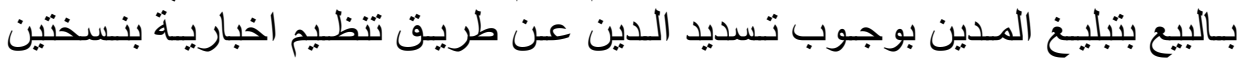

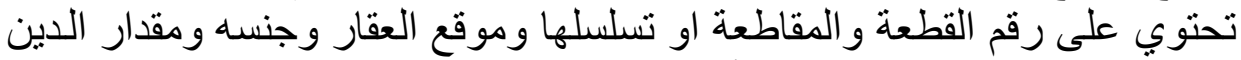

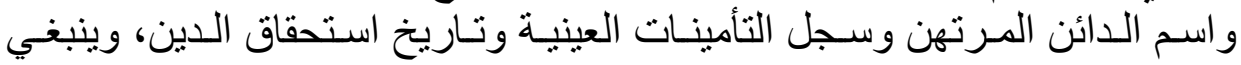

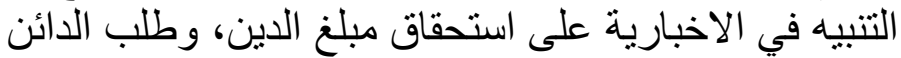

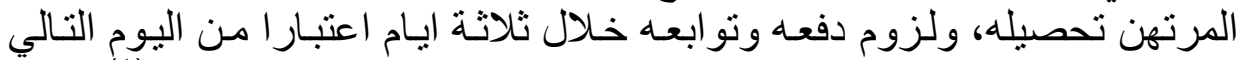

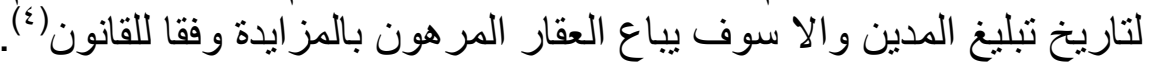

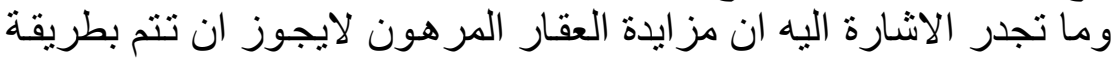

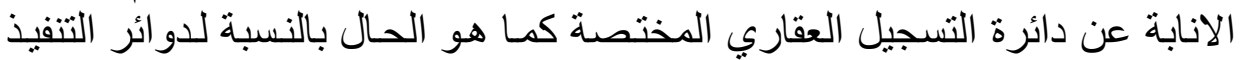

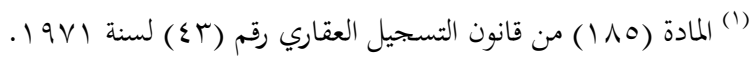

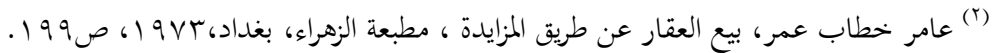

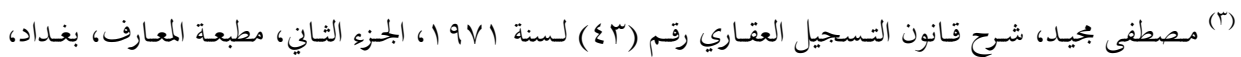$$
\text { . TITصG) } 9 \text { VA }
$$

(1) وهذه الاخبارية هي مشابهة لمذكرة الاخبار بالتنفيذ المذكورة في المادة (0) مـن قانون التنفيذ العراقي رقم (0؛ ) 


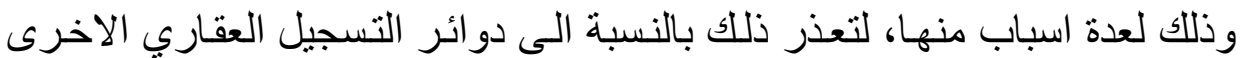

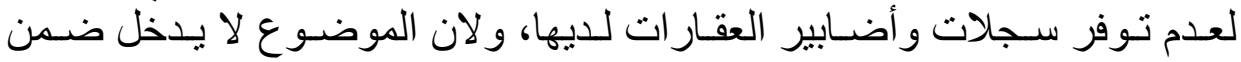

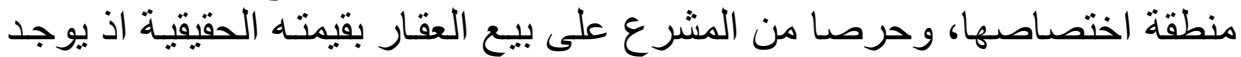

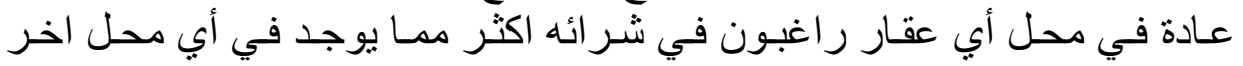

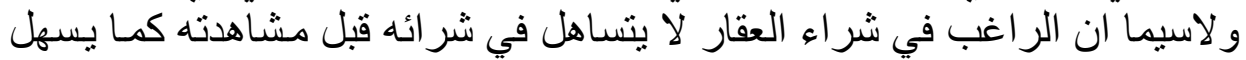

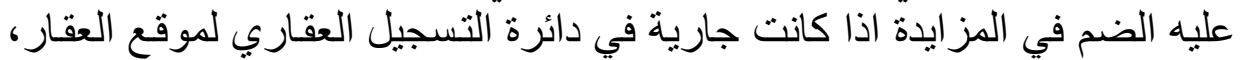

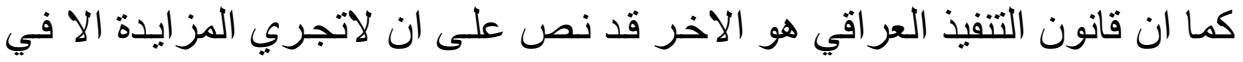

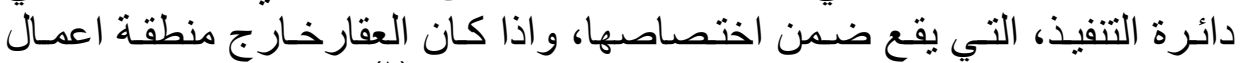

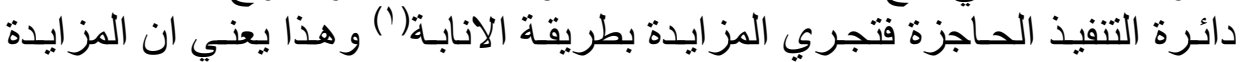

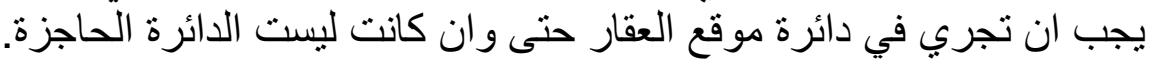

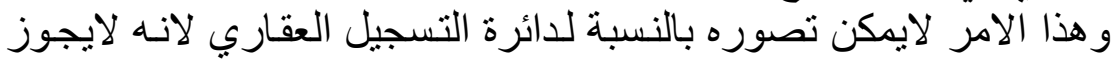

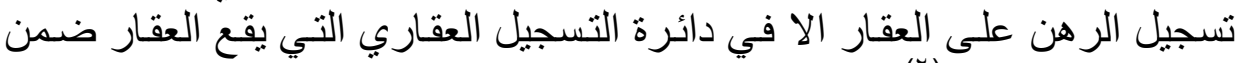

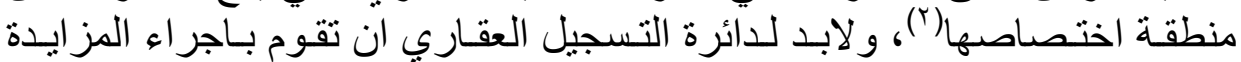

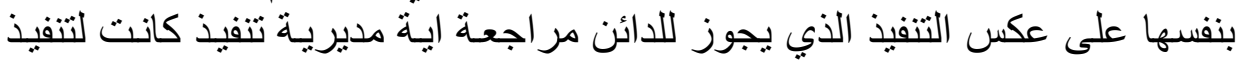
سنده.

وبعد ان تتأكد دائرة التسجيل العقاري من استحقاق الدين عند استلامها

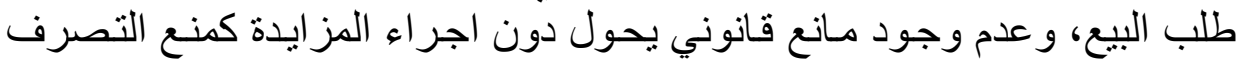

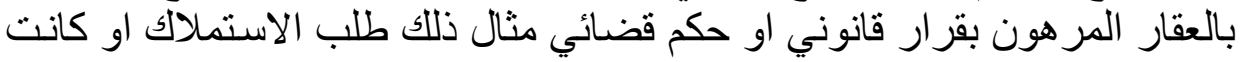

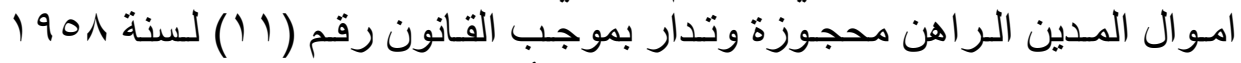

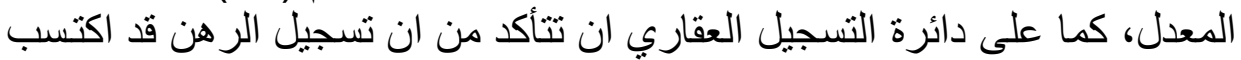

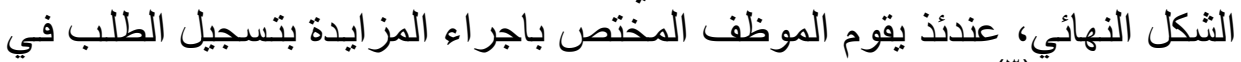

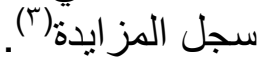

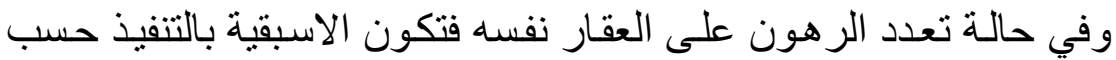
حلول اجل الدين، ثم مرتبته بحسب اسبقية التسجيل في دائرة التسجيل العقاري في في لعني

$$
\begin{aligned}
& \text { (r) المادة (V) (V) من قانون التنفيذ العراقي. } \\
& \text { (r) المادة (1 • (1) من قانون التسجيل العقاري. }
\end{aligned}
$$

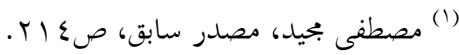


و التي تتحدد بـاليوم و اذا كان هنالك عدة رهونـات مسجلة في نفس اليوم فحسب

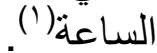

ثانيا- تبليغ المدين الراهن: اوجب القانون على دائرة التسجيل العقاري اخبار المدين الر اهن باخباريـة

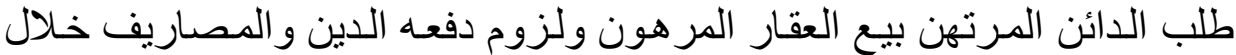

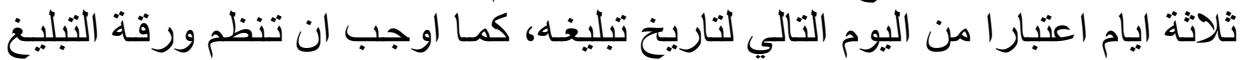

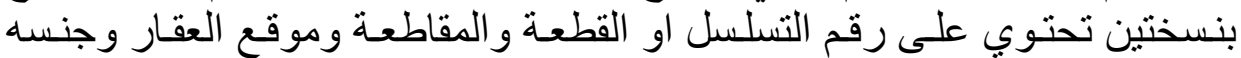

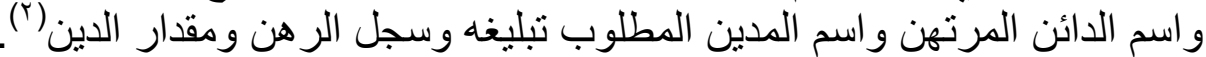

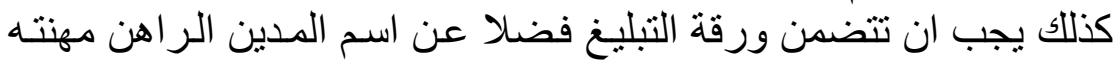

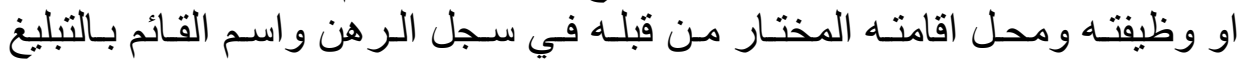

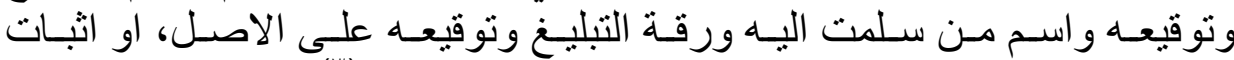

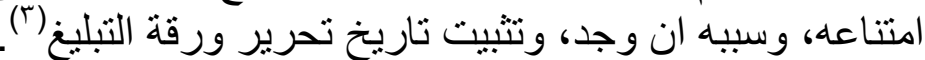

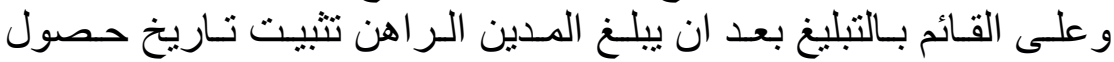

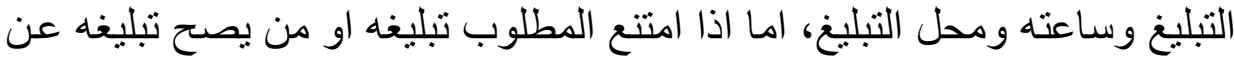

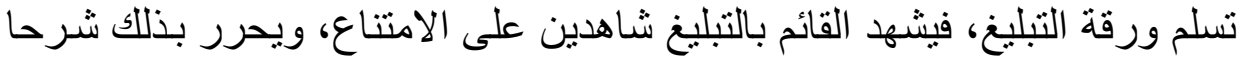

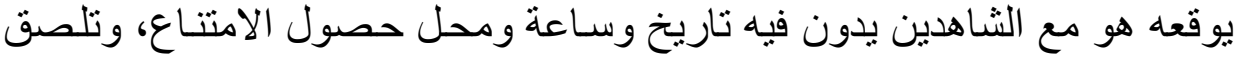

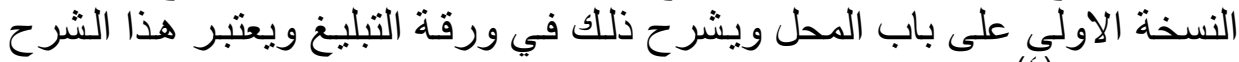

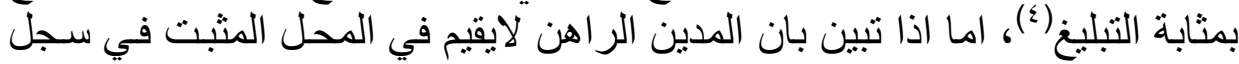

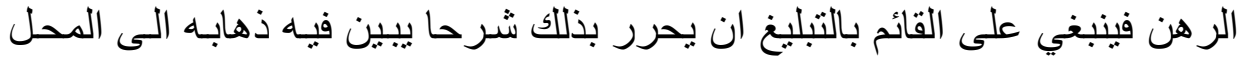

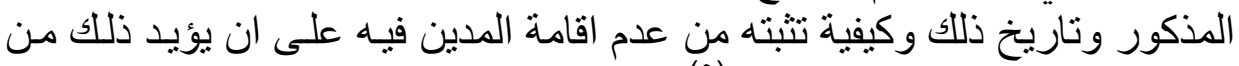

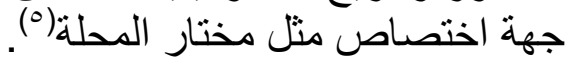

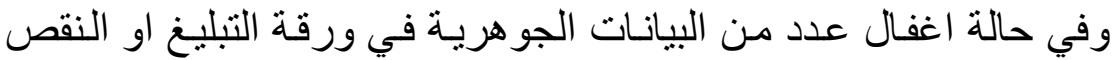

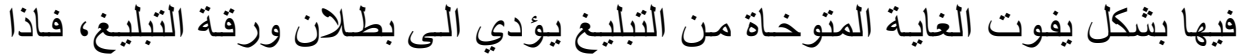
كانت الورقة خالية من المدة التي ينبغي تسديد الدين خلالهها، فان هذا التبلين التيغ يعد

$$
\text { ومابعدها. }
$$




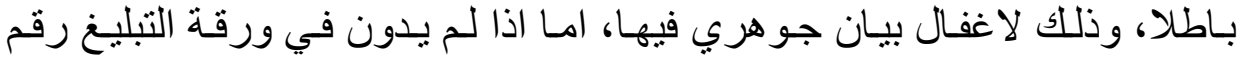

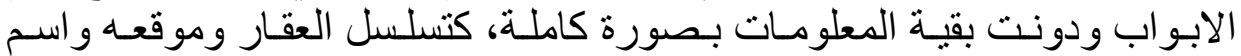

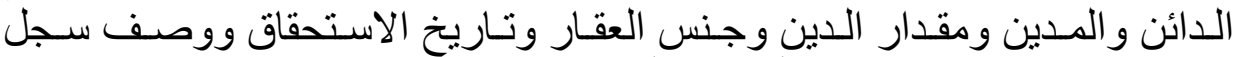

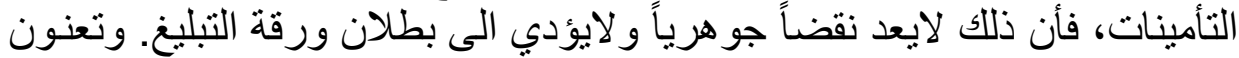

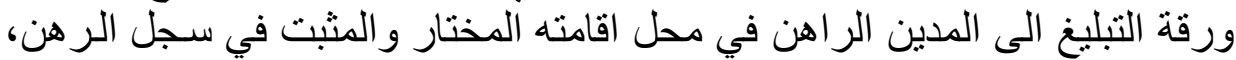

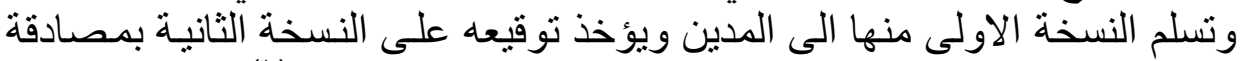

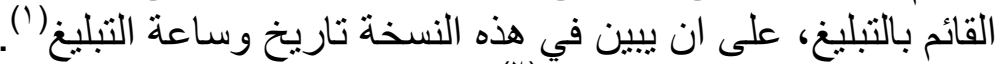

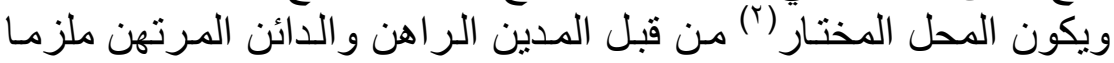

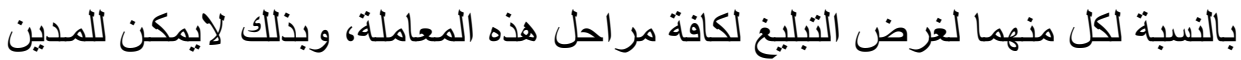

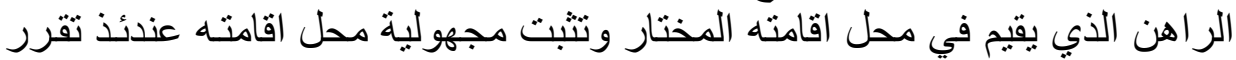

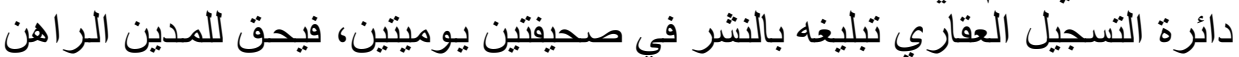

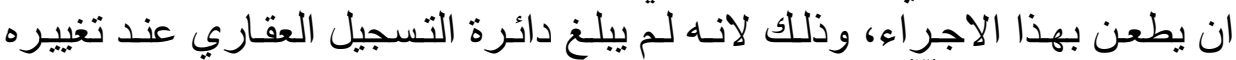

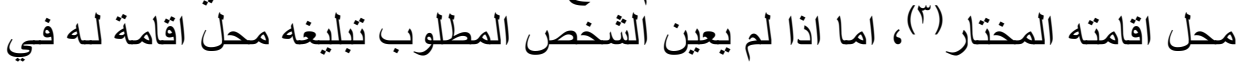

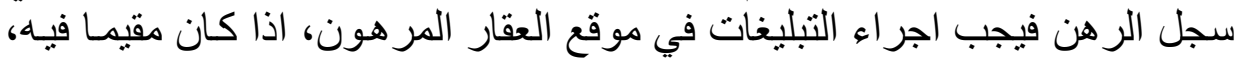

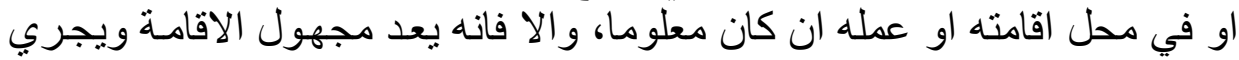

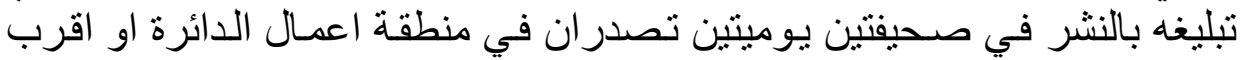

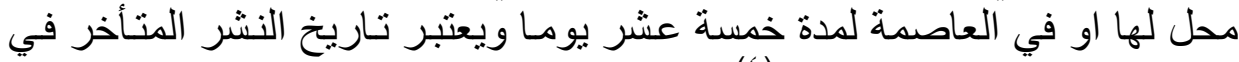

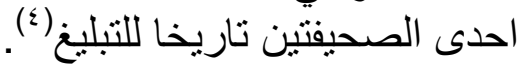

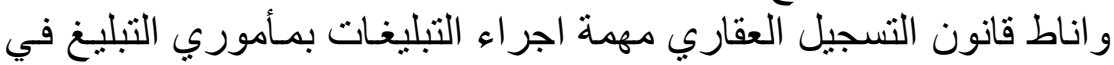

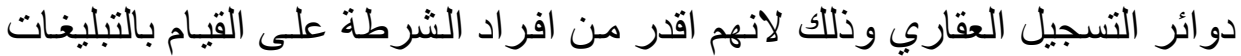

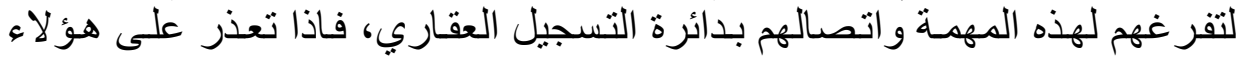

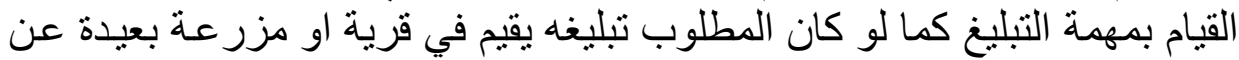

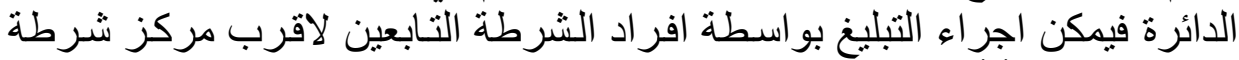

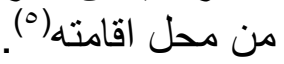

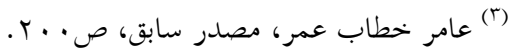

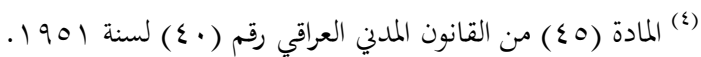

$$
\begin{aligned}
& \text { (0) مصطفى بحيد، مصدر سابق، ص • (1) } \\
& \text { (1) المادة (VT (1) من قانون التسجيل العقاري. }
\end{aligned}
$$

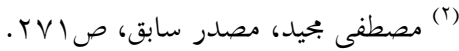




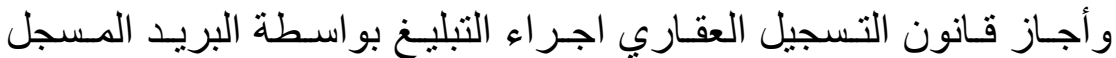

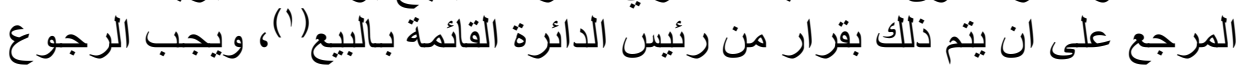

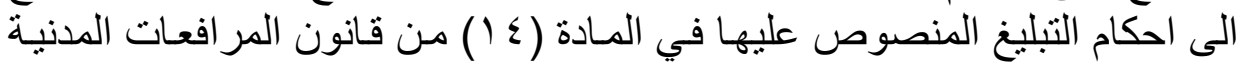

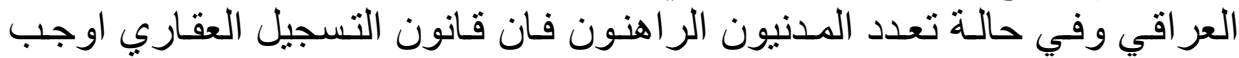

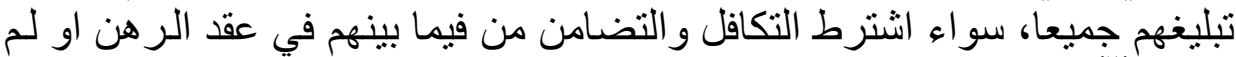

يشترط (r) (ب)

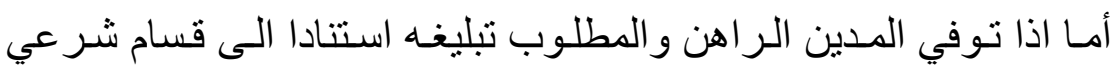

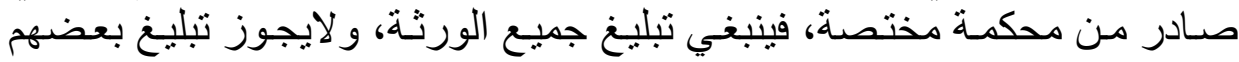

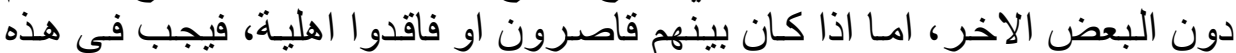

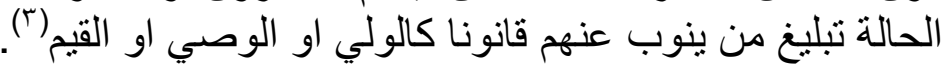

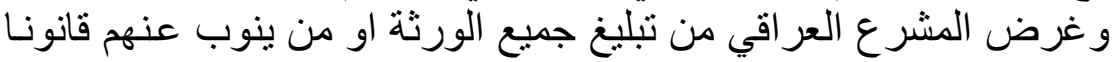

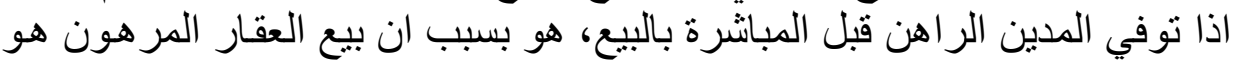

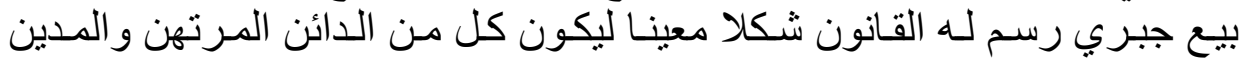

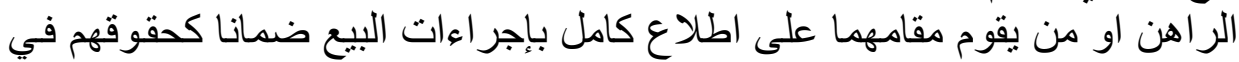

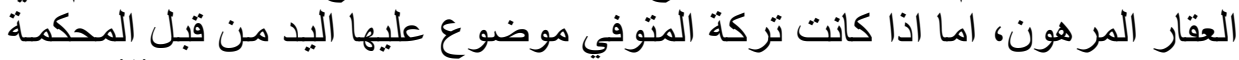

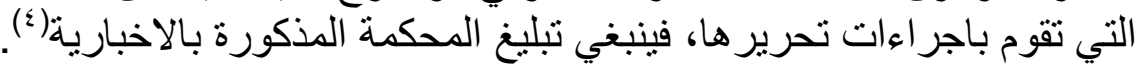

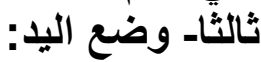

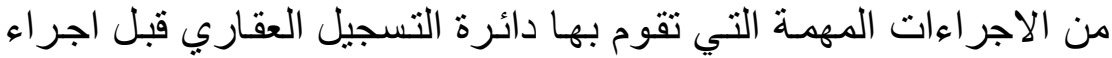

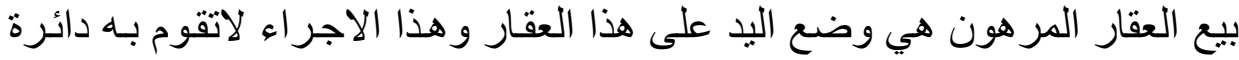

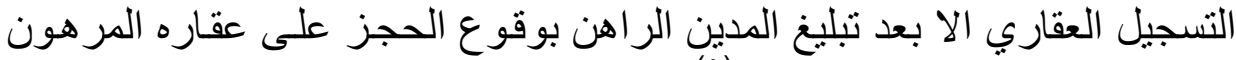

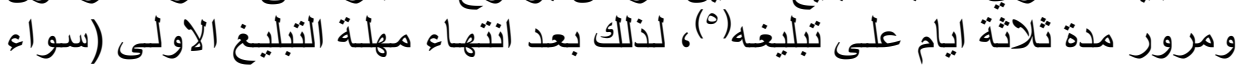

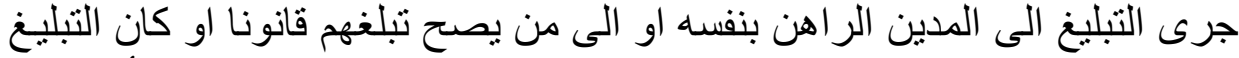

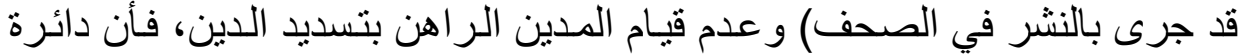

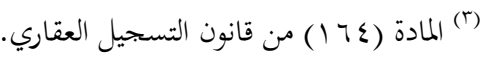

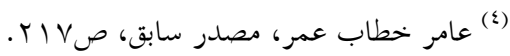

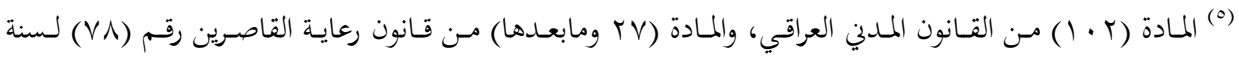

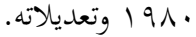

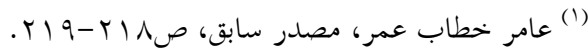

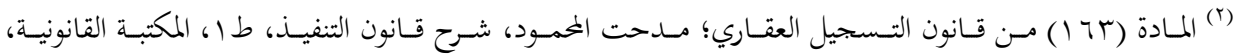

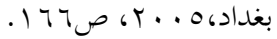


التسجيل العقاري تقوم بوضع اليد على العقار المطلوب بيعه وذللك من قبل رئيس التبس

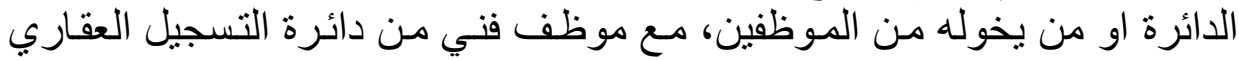

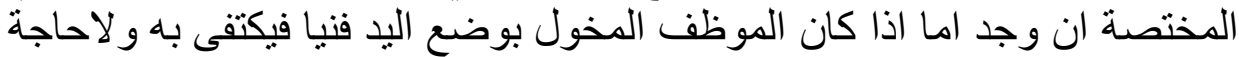

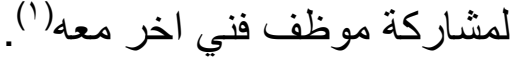

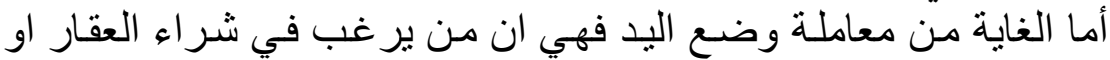

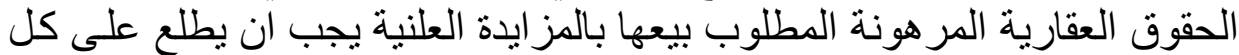

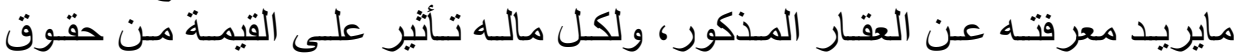

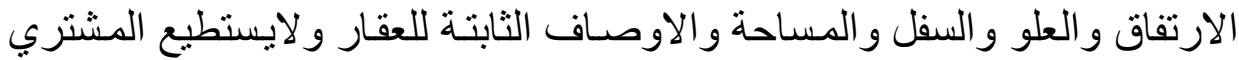

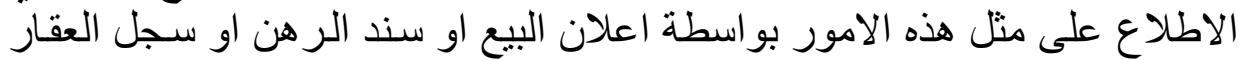

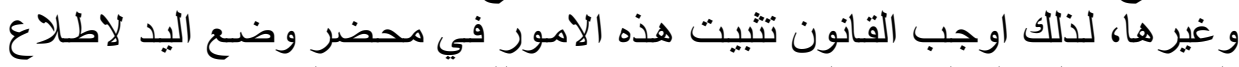

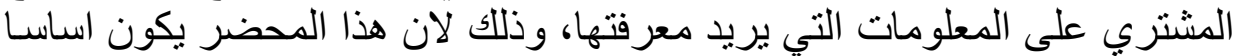

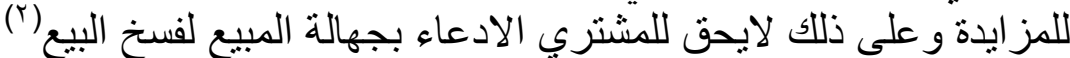

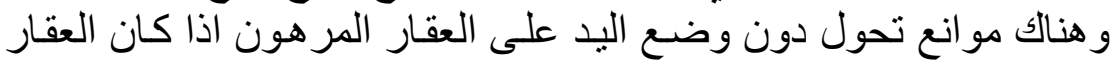

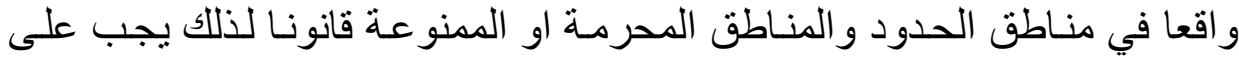

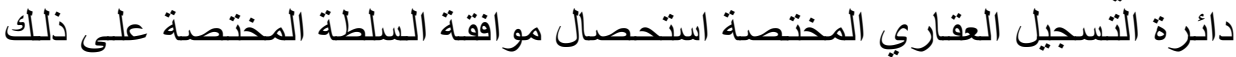
مسبقا ، كالوحدات الادارية او السلطة العسكرية و غير هاب(؟).

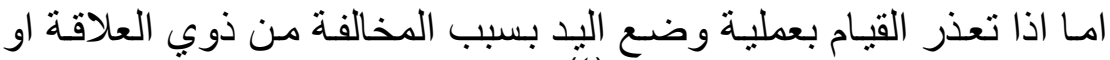

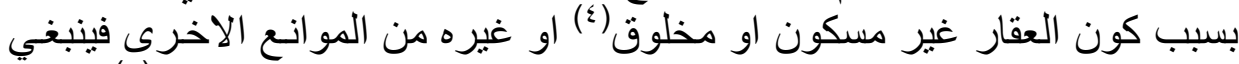

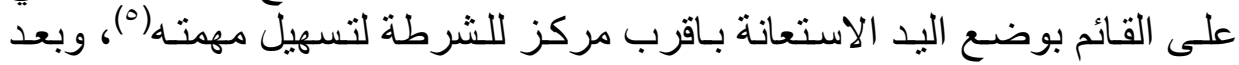

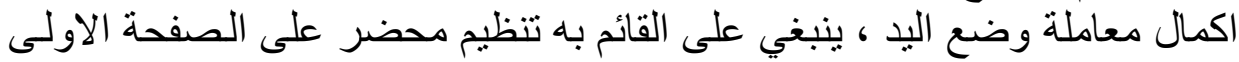

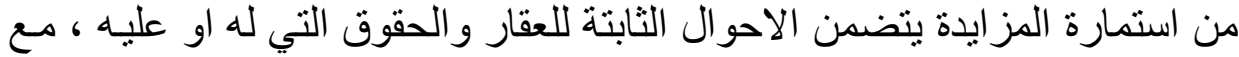

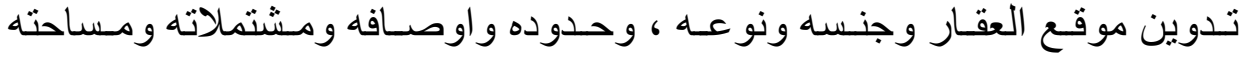

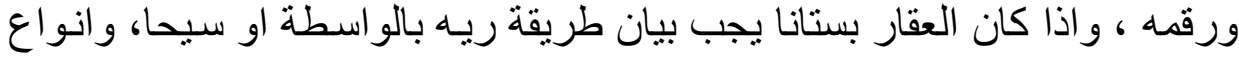

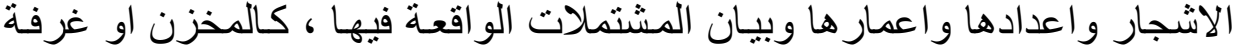

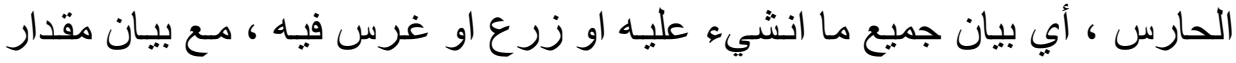

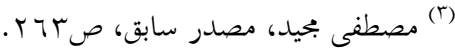

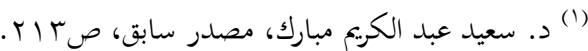

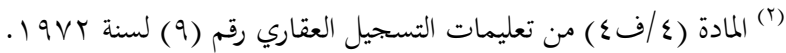

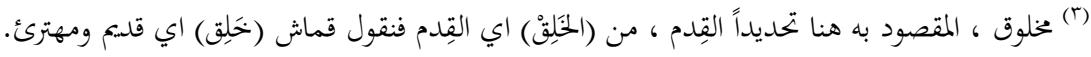

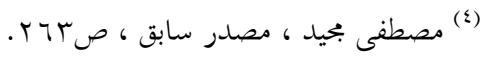




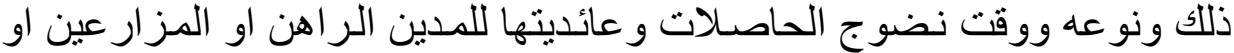

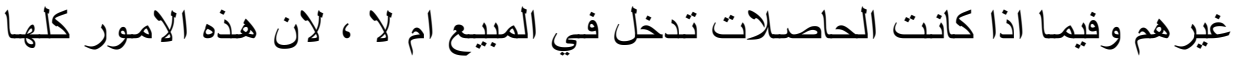

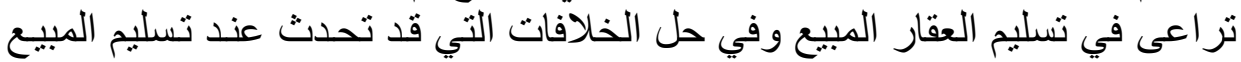

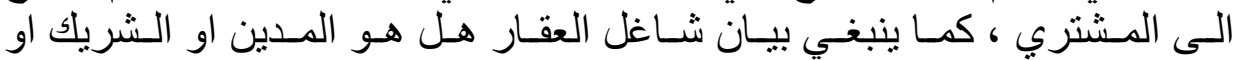

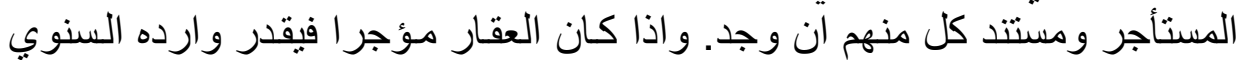

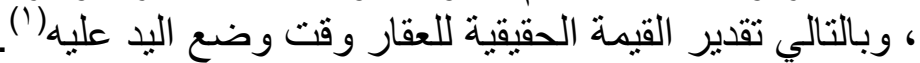

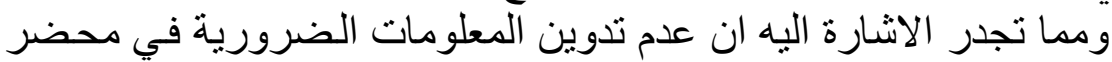

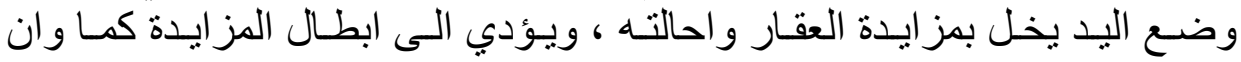

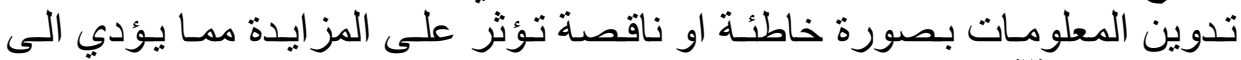

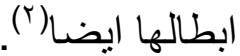

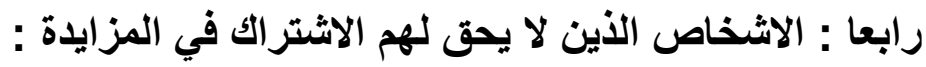

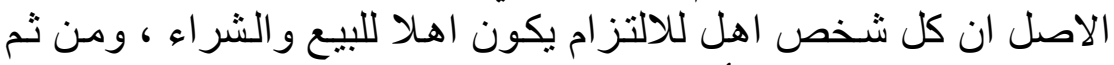

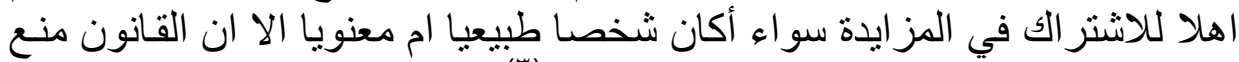

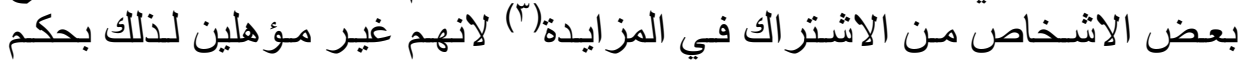

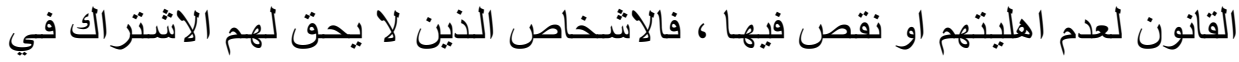

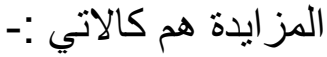

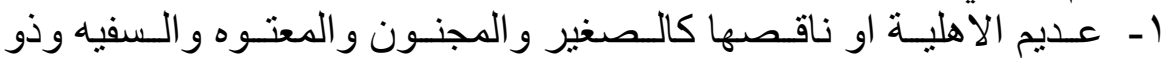

\section{الغفلة (ع) الخائ}

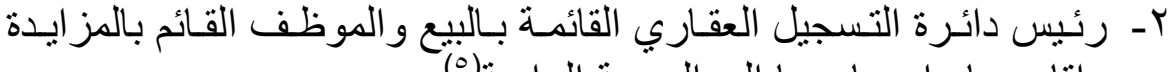

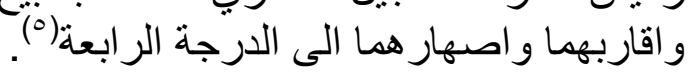

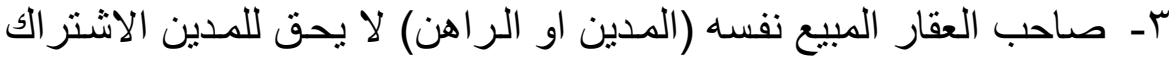

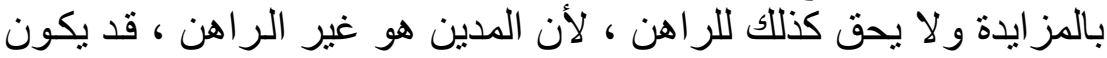

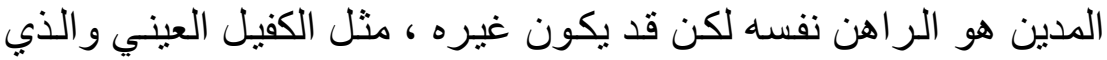

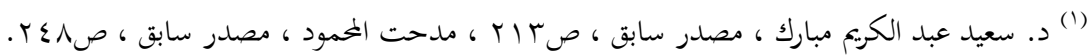

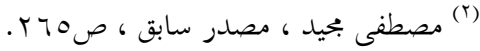

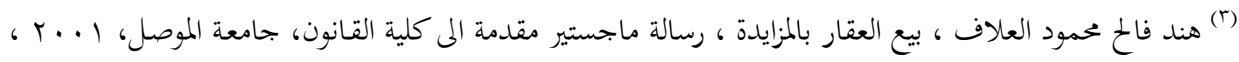

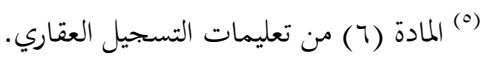


هو ليس ملزماً أصلاً بالدين لكنه تقدم وقدم عقاره لضمان ذلك الدين فكان راهنا غير مدين.

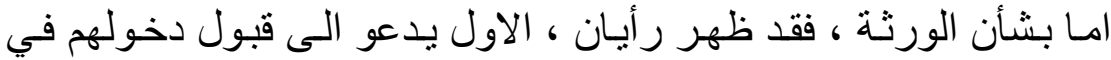

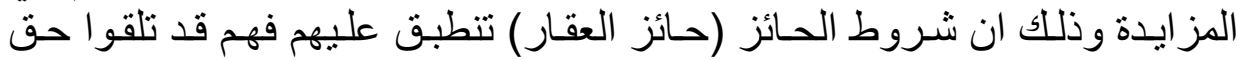

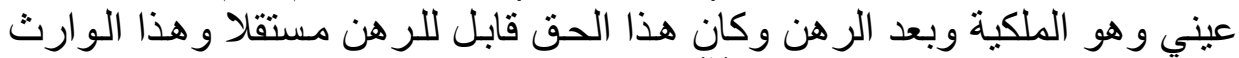

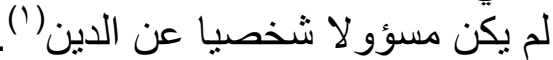

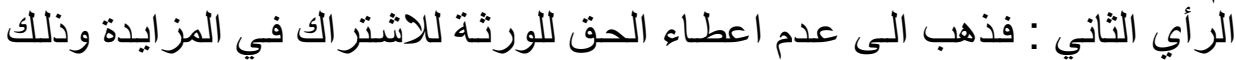

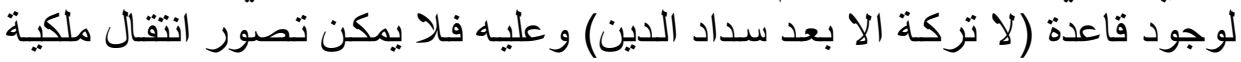

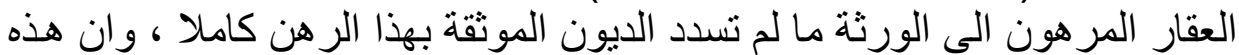

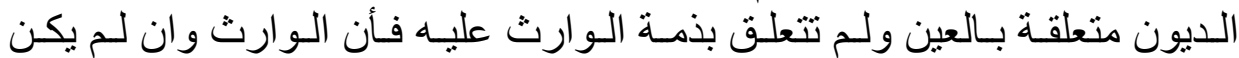

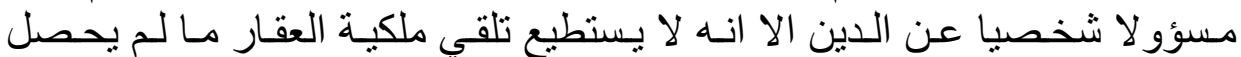

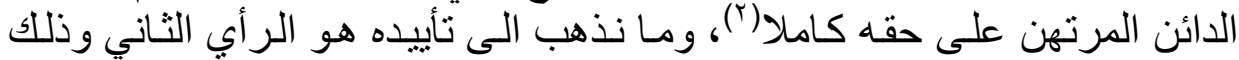

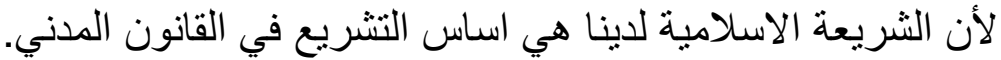

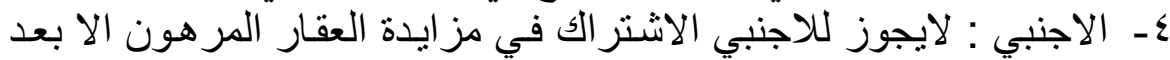

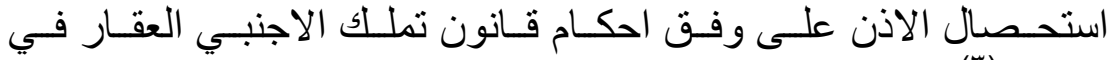

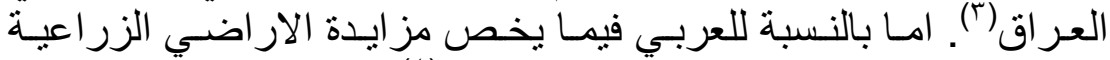

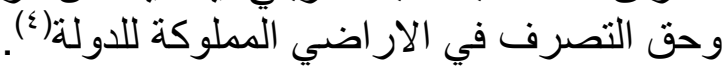

خامسا : الاعلان عن البيع : الانهي

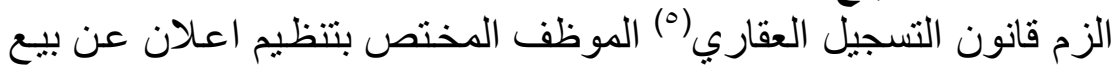

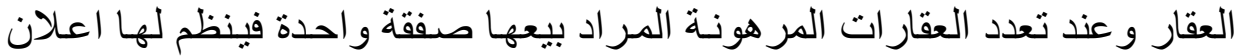

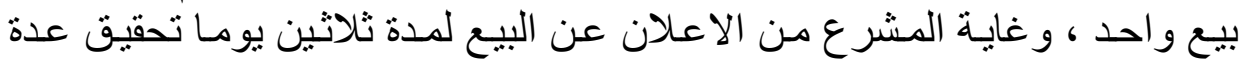

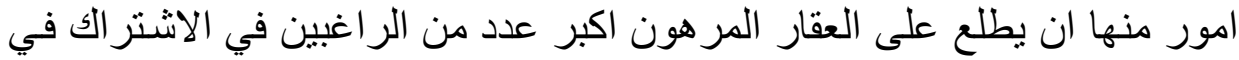

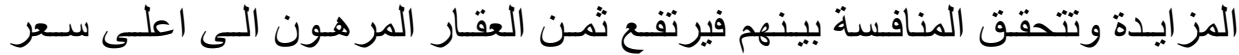

$$
\text { (1) (1) مصطفى بحيد ، مصدر سابق ، صع Y Y. }
$$

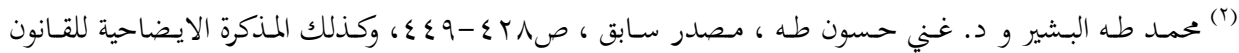

$$
\begin{aligned}
& \text { المدني المصري ، جل ، دون مكان وسنة طبع ، صع } 9 . \\
& \text { (") المادة (ع اه 1) من قانون التسجيل العقاري. }
\end{aligned}
$$

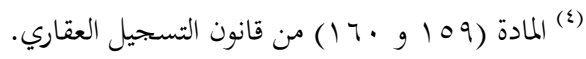

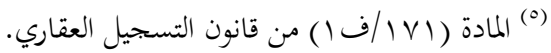


ممكن( ')، و لأجر اء البيع بصورة علنيـة وسليمة وخاليـة من التو اطؤ وبـأعلى ثمن فئ

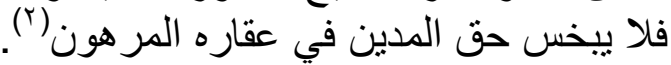

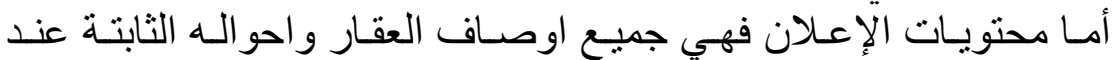

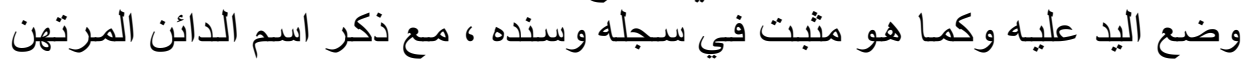

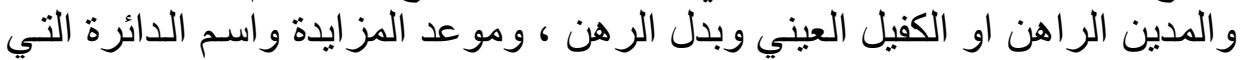

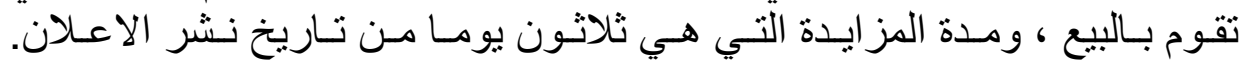

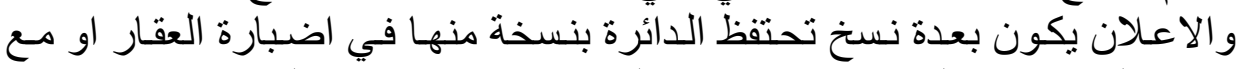

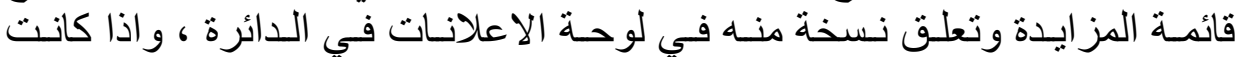

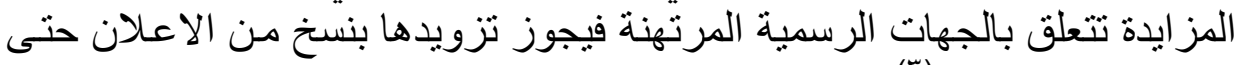

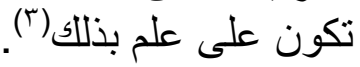

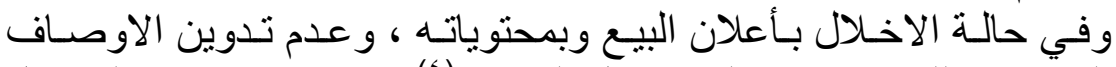

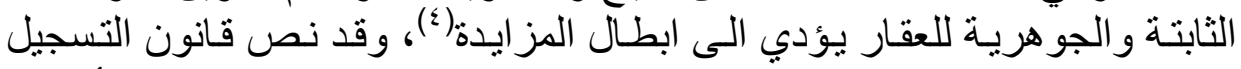

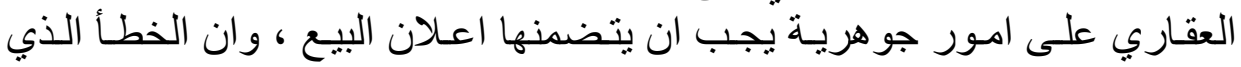

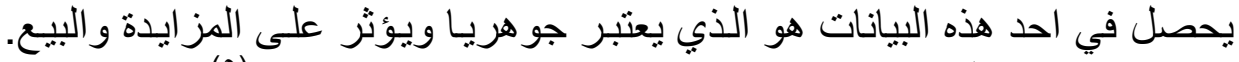

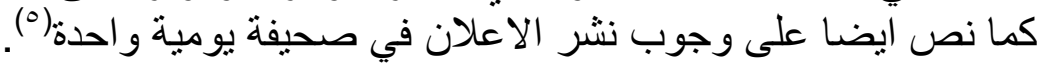

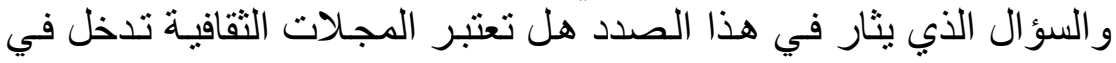

تعريف الصحيفة

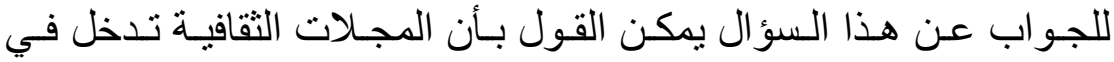

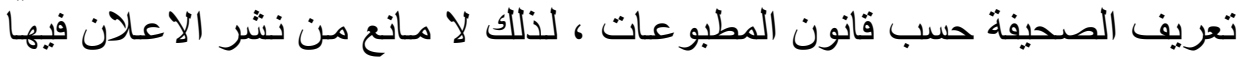

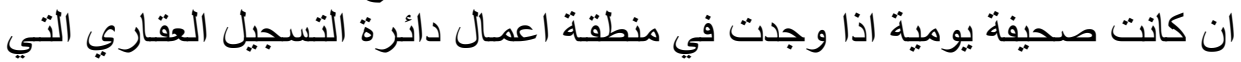

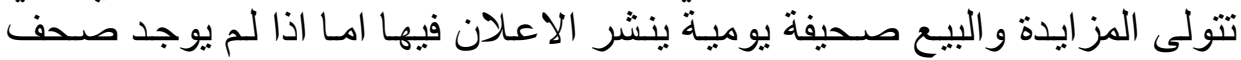

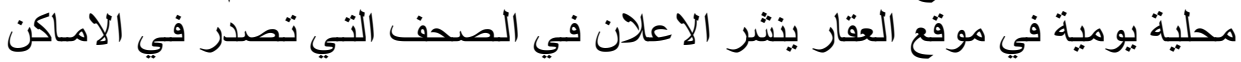

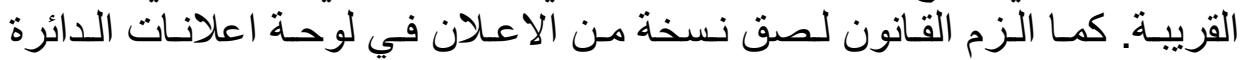

(1) د. ادم وهيب النداوي ، احكام قانون التنفيذ ، شرح قانون التنفيذ العراقي ، رقم (0 ) لسنة . 191 1 ، ط1 ،

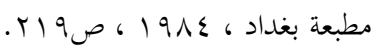

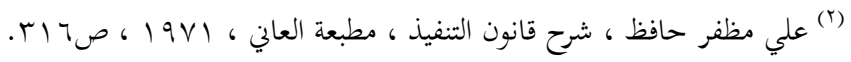

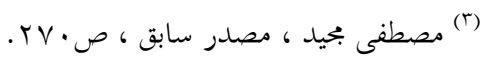

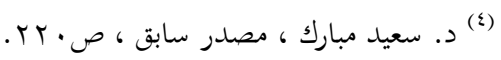

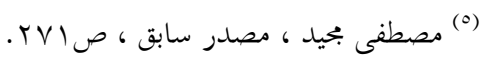


القائمة بالبيع لاطلاع اكبر قدر من الناس عليها(')، وتبدأ مدة الاعلان من اليوم

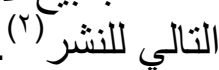
سادسا : التأمينات القانونية :

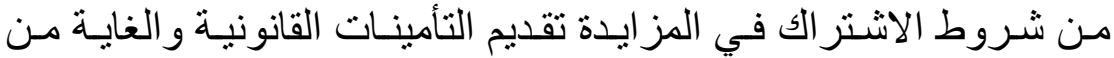

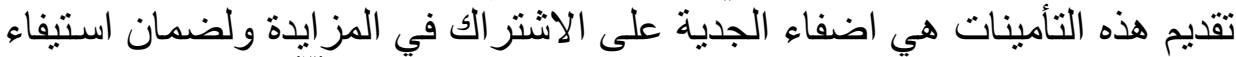

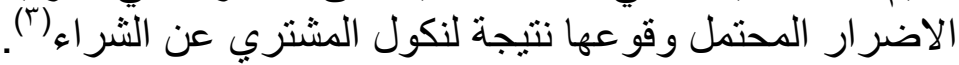

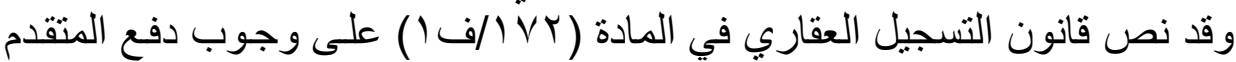

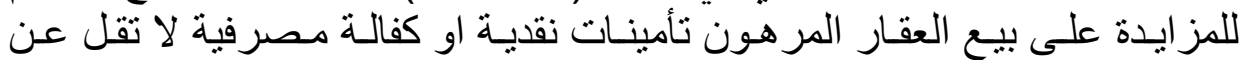
(·٪) من القيمة المقدرة للعقار المر هون.

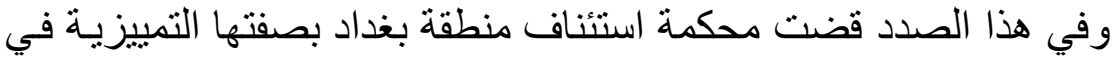

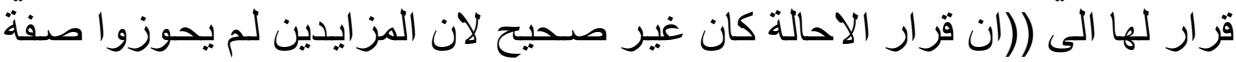

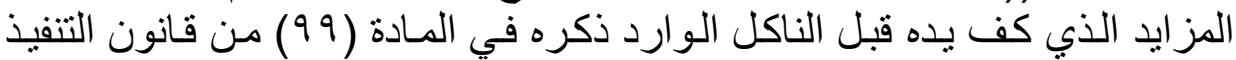

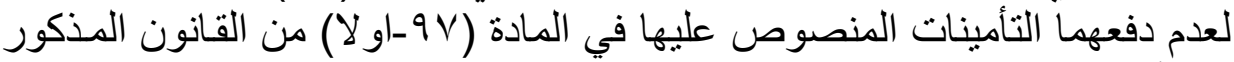

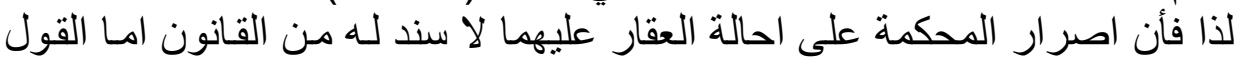

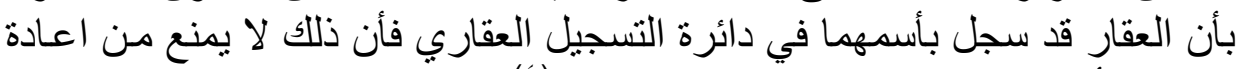

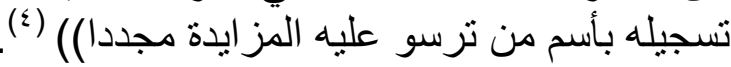

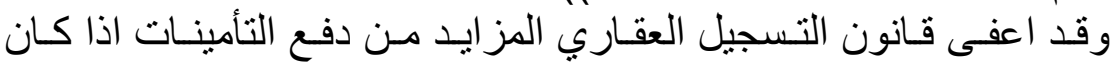

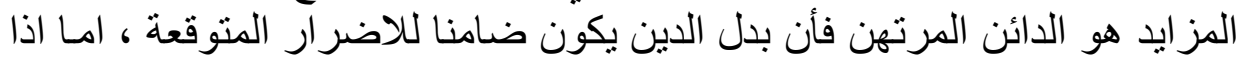

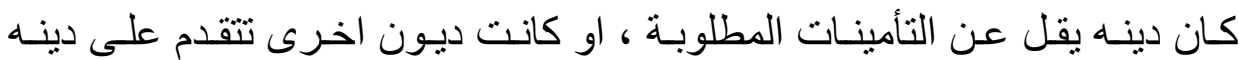

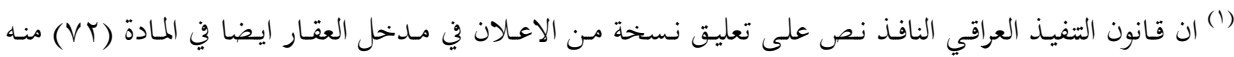
فضلا عن تعليق نسخة في الدائرة ، ولكن قانون التسجيل العقاري اشترط تعليق نسخة من الاعلان في الدائرة فقط

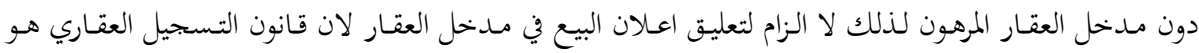

$$
\text { الوادب التطبيق. }
$$

(") د. فاروق احمد خماس ، محمد عبد الله الدليمي ، الوجيز في النظرية العامة للعقود الادارية ، دار الكتب للطباعة العاري

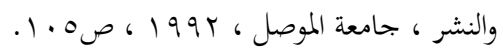

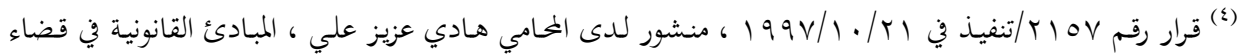

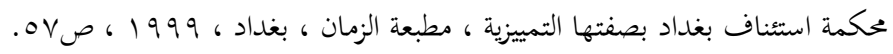


بالمرتبة فيجب في هذه الحالة دفع التأمينات اللازمـة او مـا يكملها حسب مقتضى الحال( الحرد)

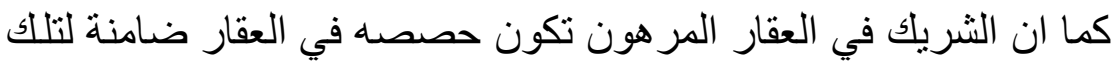

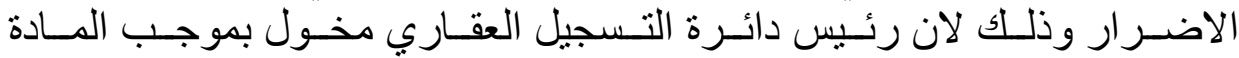
(Y ب l V0)

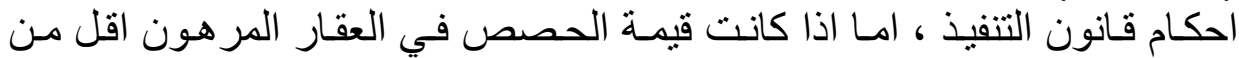

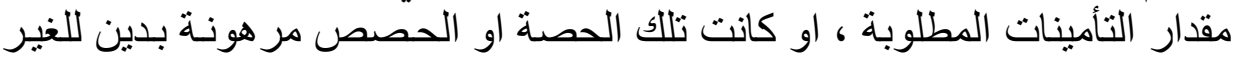

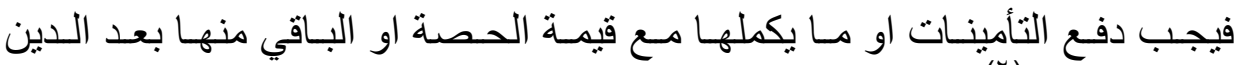

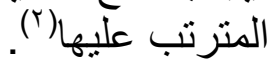

\section{|}

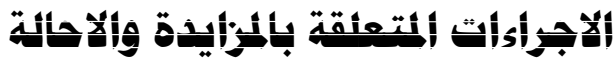

$$
\text { اولا - المزايدة والاحالة : الإن }
$$

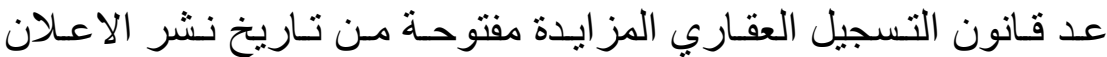

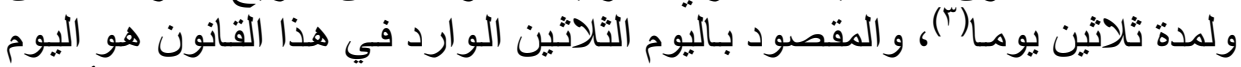

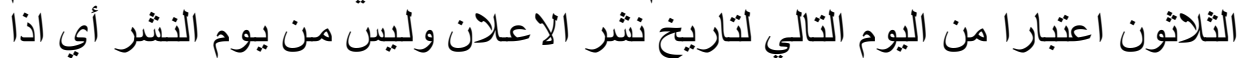

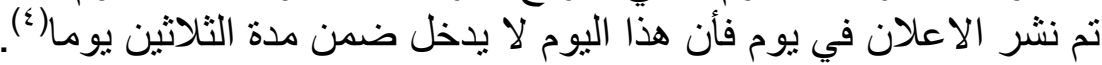

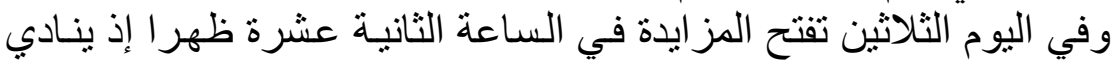

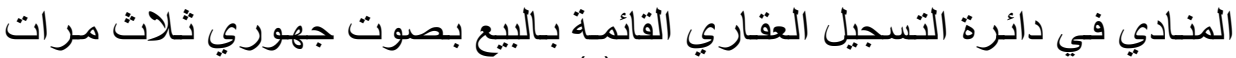

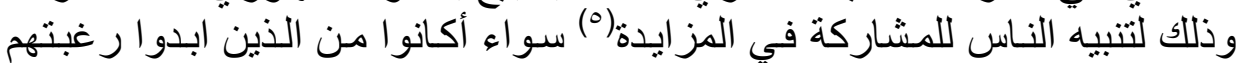

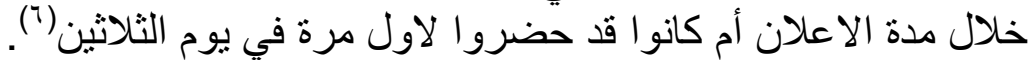

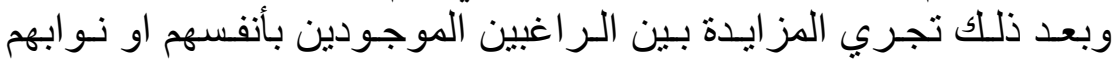

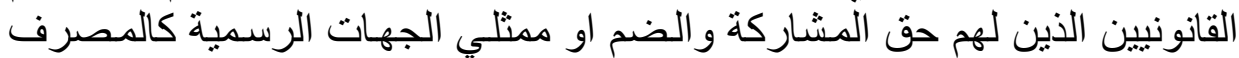

$$
\begin{aligned}
& \text { (1) مصطفى بجيد ، مصدر سابق ، صV^. (1) (1) }
\end{aligned}
$$

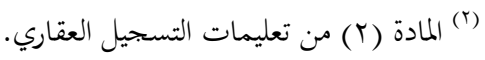

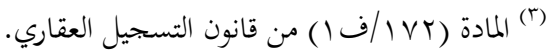

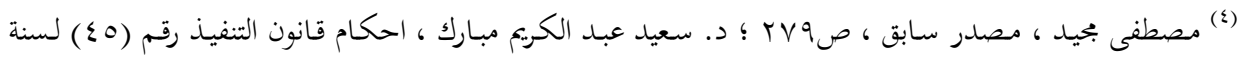

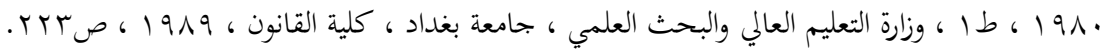

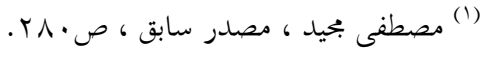

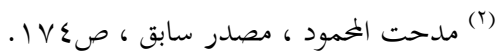




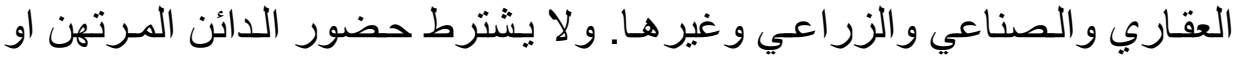

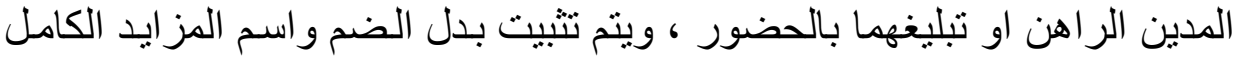

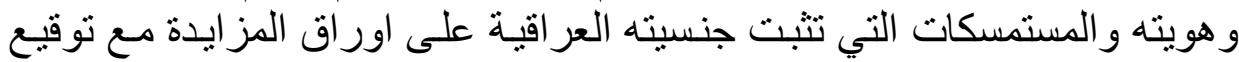

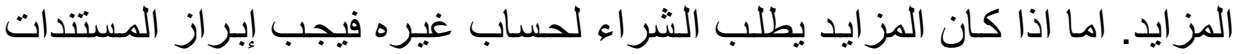

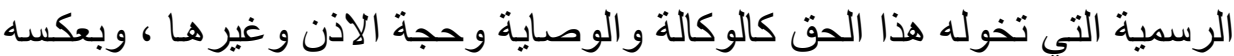
لا يقبل منه آلضم الا لحسابه (').

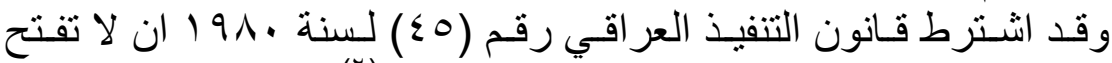

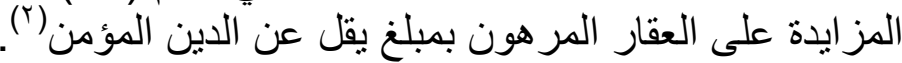

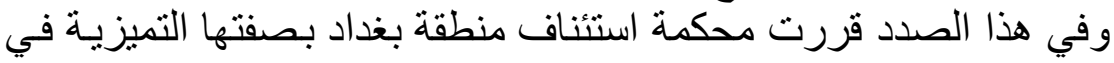

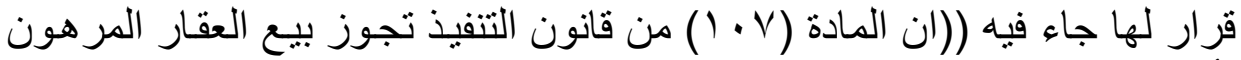

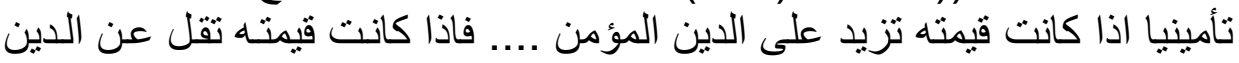

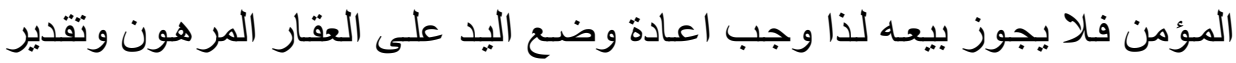

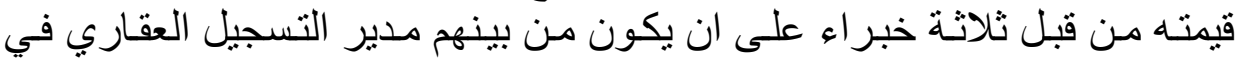

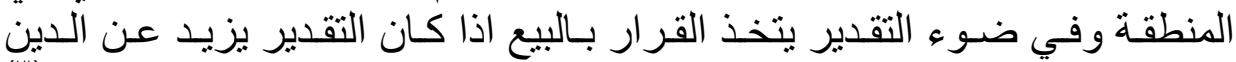

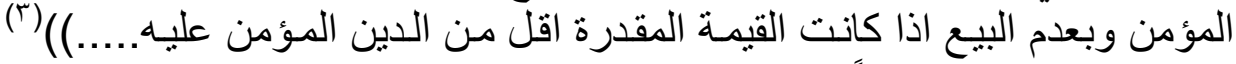

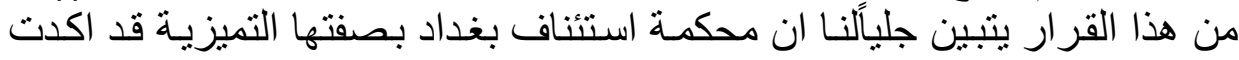

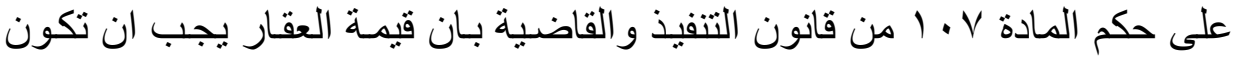

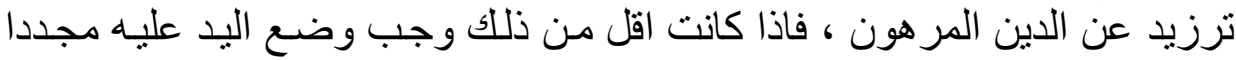

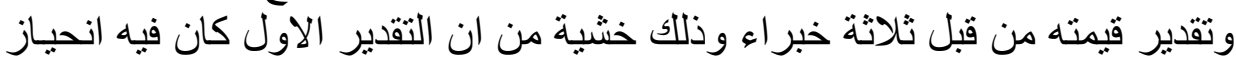

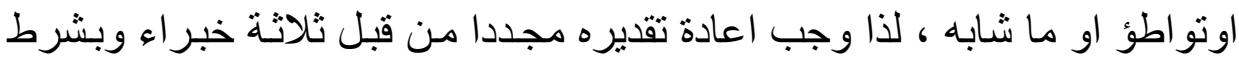

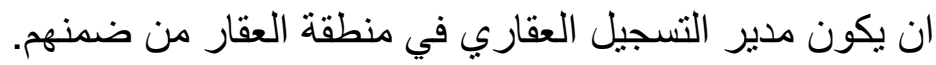

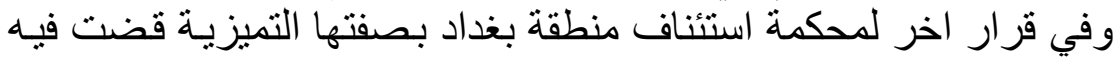

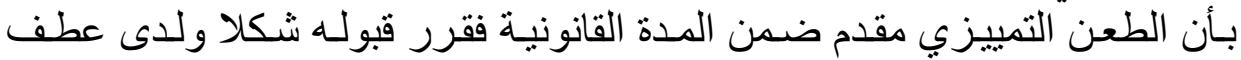

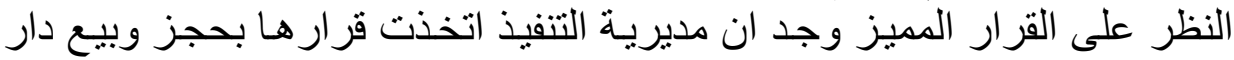

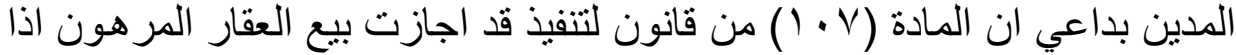

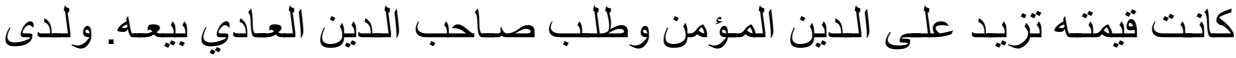

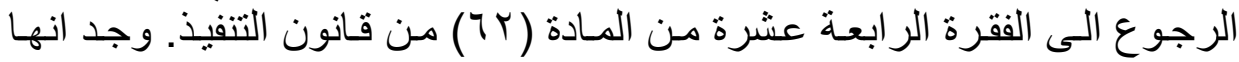

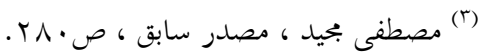

$$
\begin{aligned}
& \text { (و) المادة (V • (1) من قانون التنفيذ العراقي. }
\end{aligned}
$$

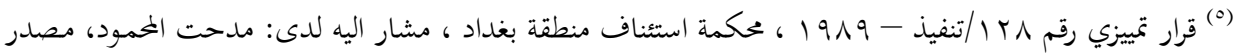




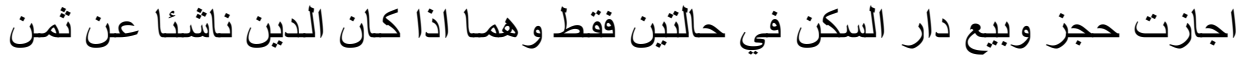

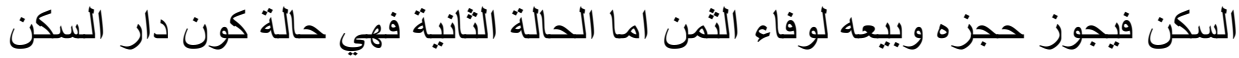

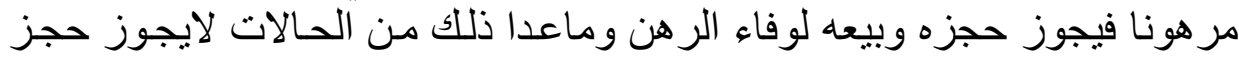

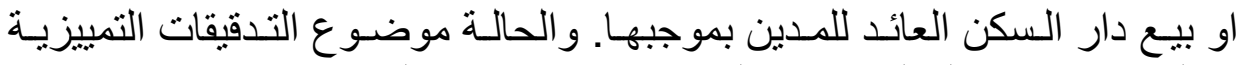

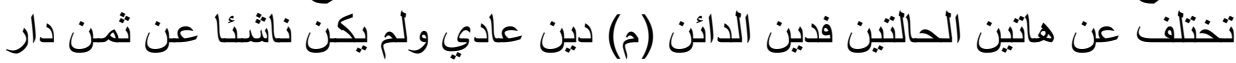

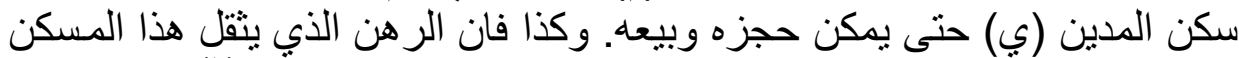

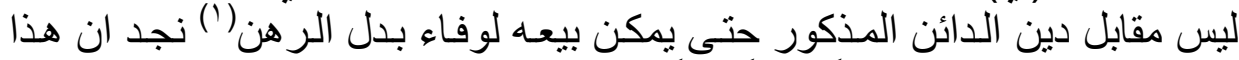

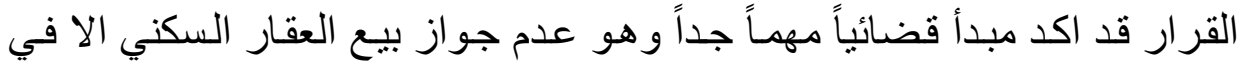

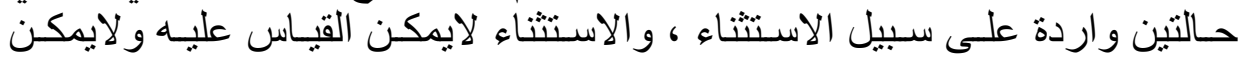

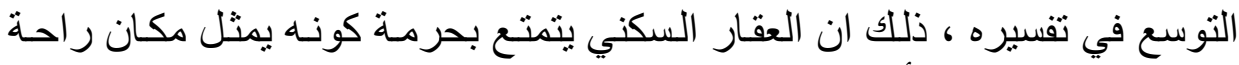

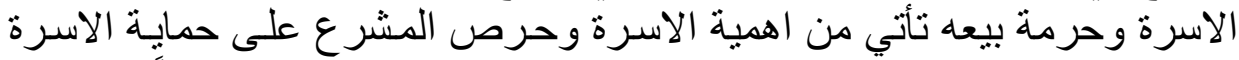

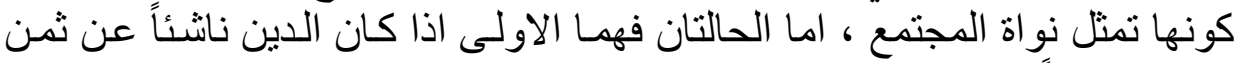

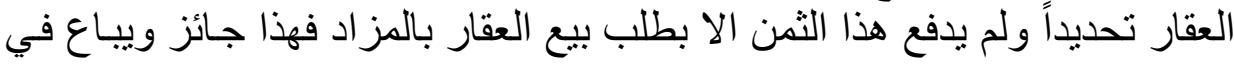

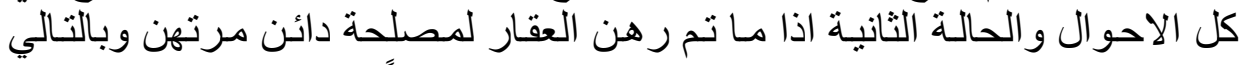

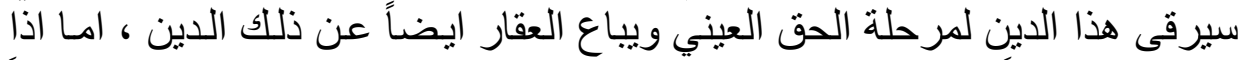

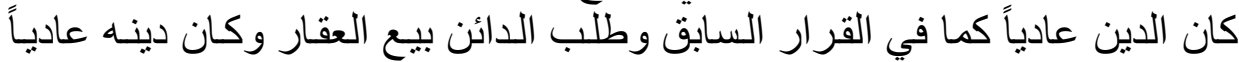

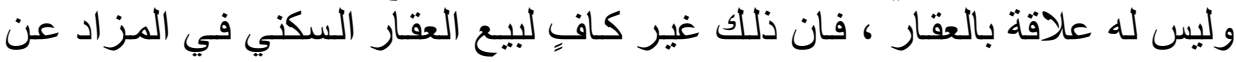
طريق دائرة التنفيذ.

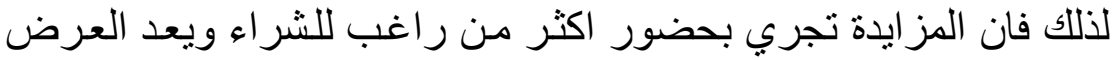

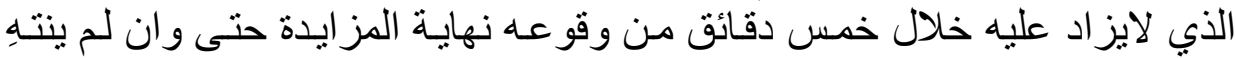

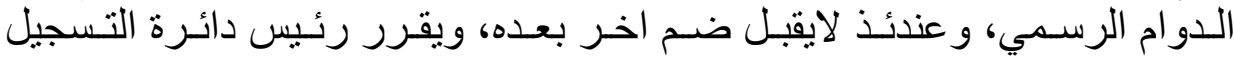

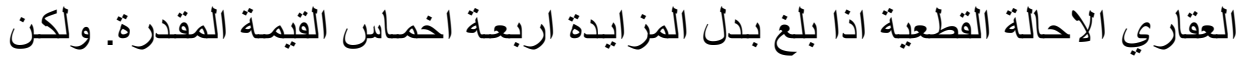

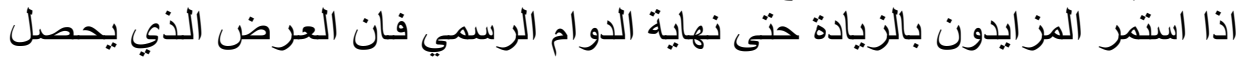

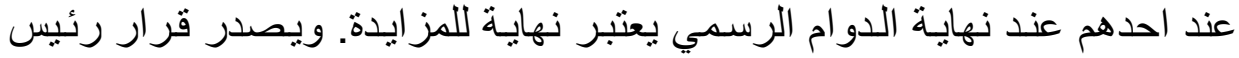

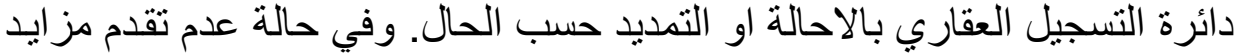

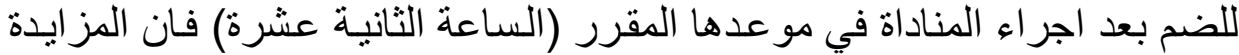

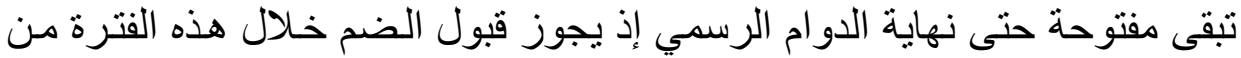

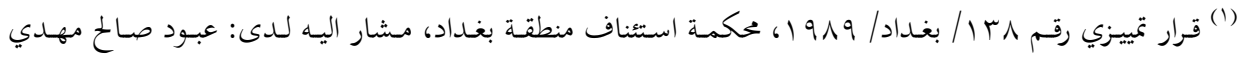

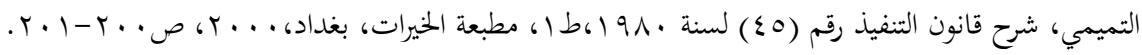




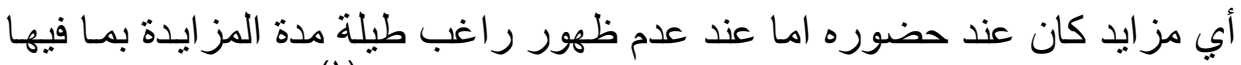

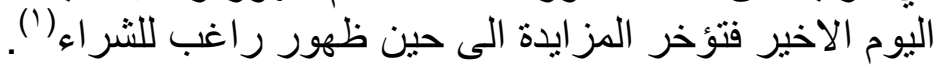

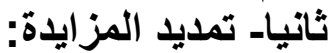

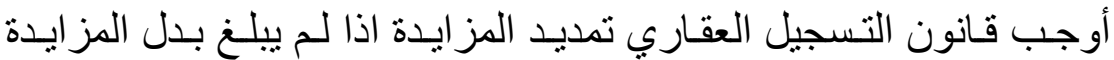

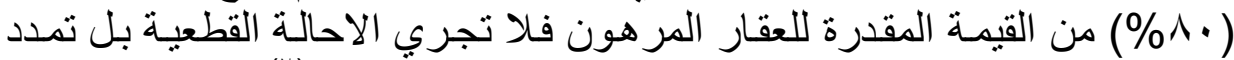

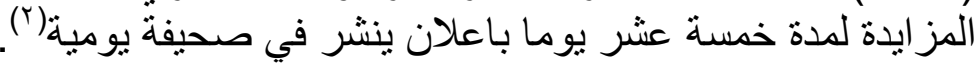

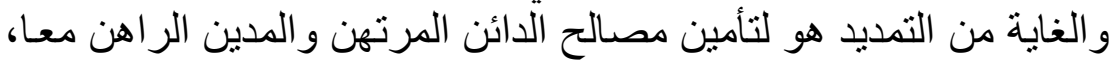

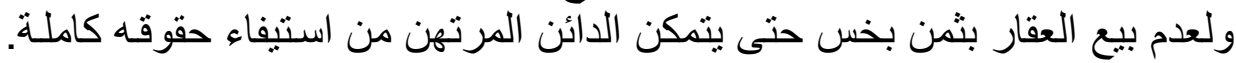

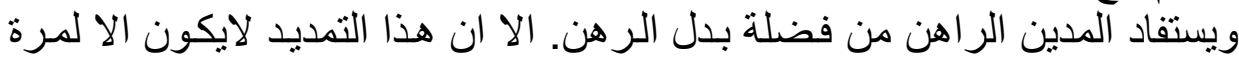

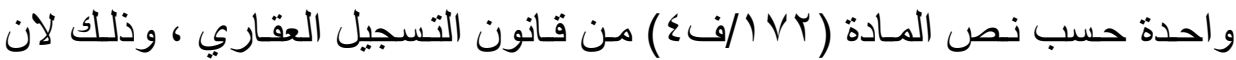

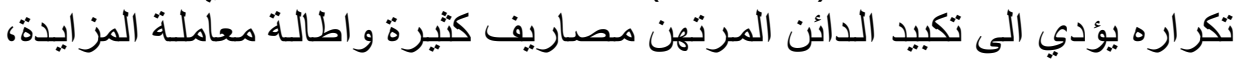

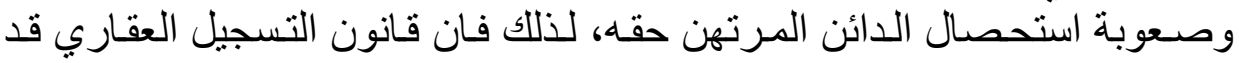

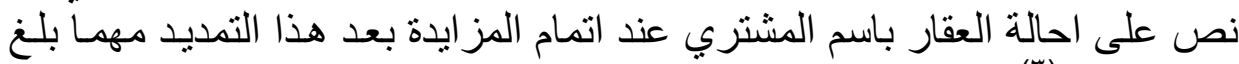

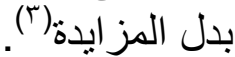

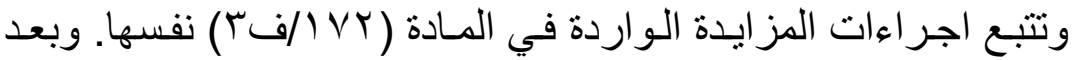

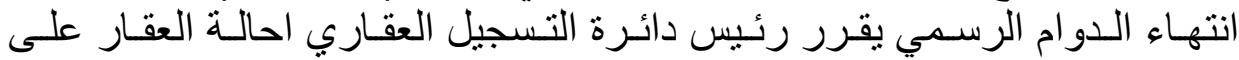

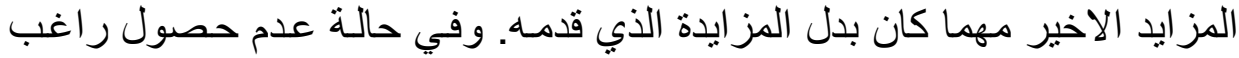

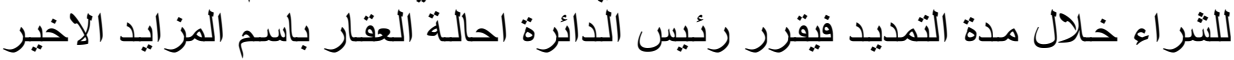

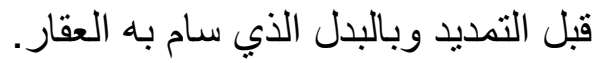

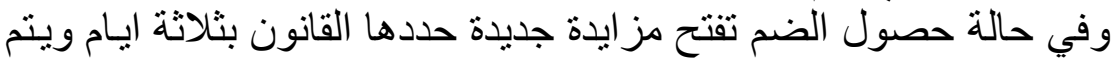

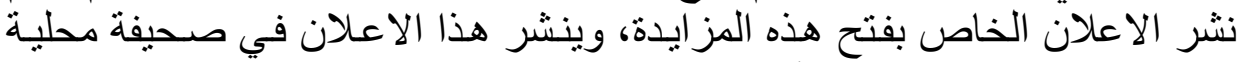

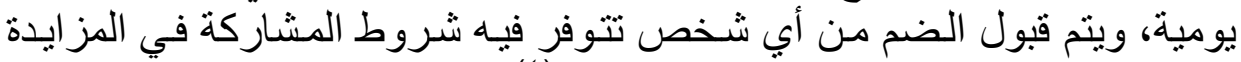

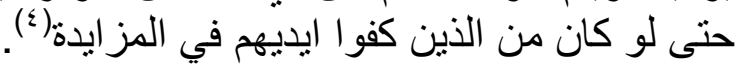

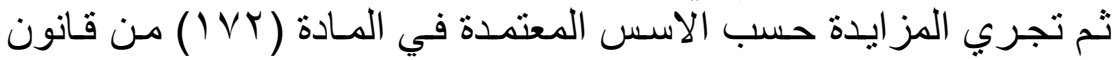

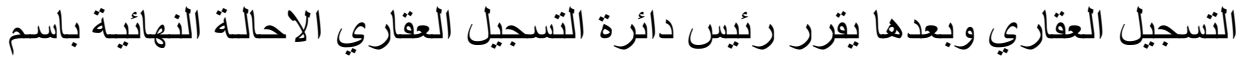

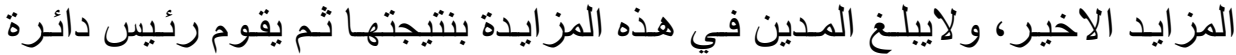

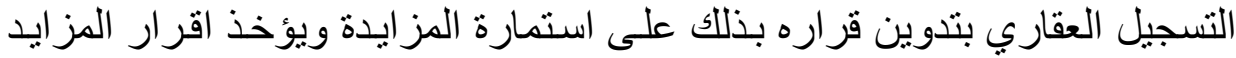

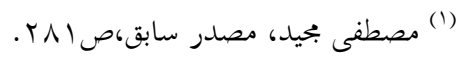

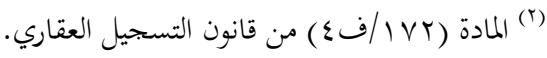

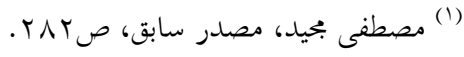

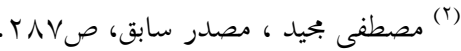


الاخير على ذلك ايضا ويلصق طابع مالي على شرح قبول المز ايد شـر اء العقار

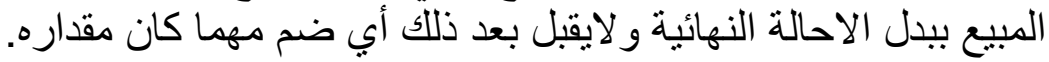

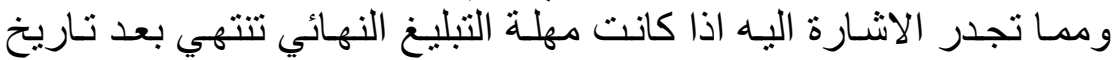

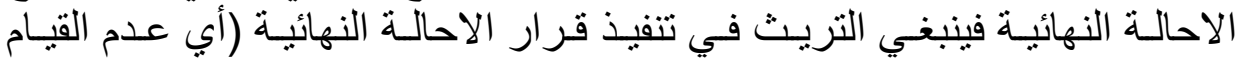

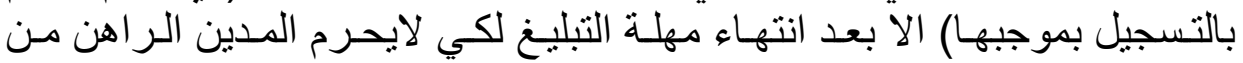
المهلة التي منحها له القانون لتسديد الدين.

ثالثاء الضم بعد الاحالة القطعية:

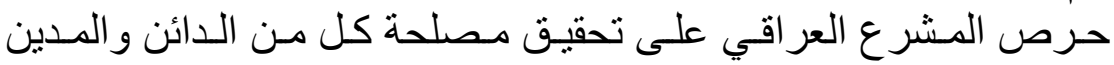

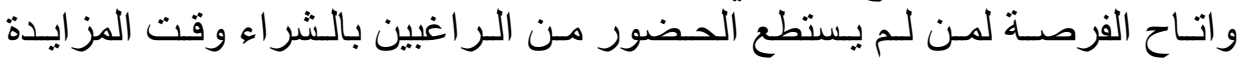

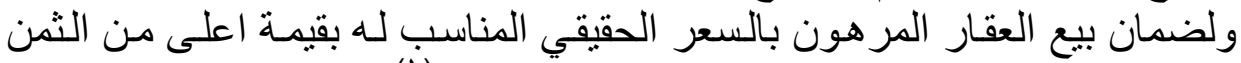

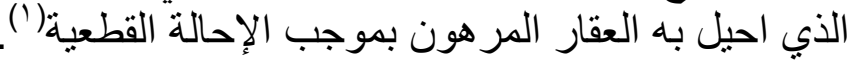

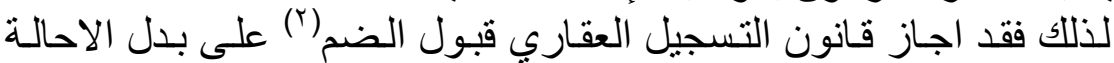

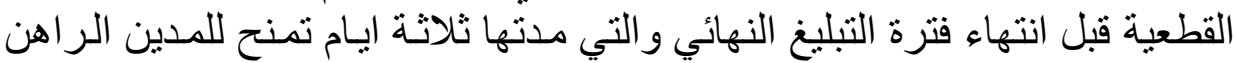

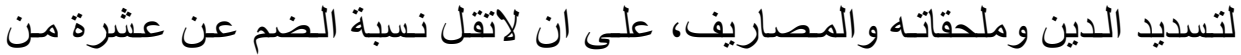

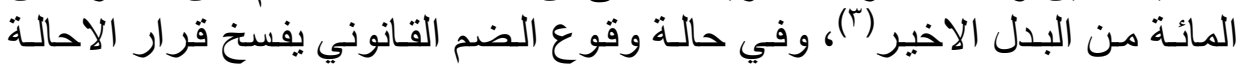

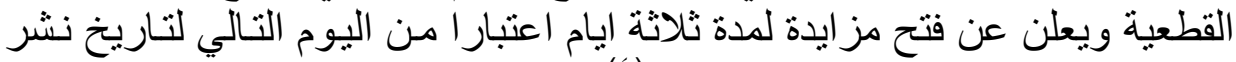
الاعلان ثم تجري بعدها الاحالة النهائية( أ). وحدد قانون التسجيل العقاري شروط الضئر الضم (0) بالاتي:

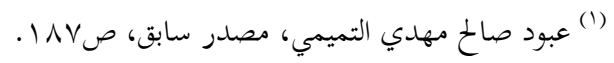

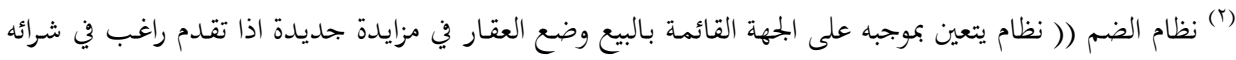

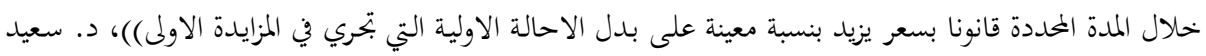

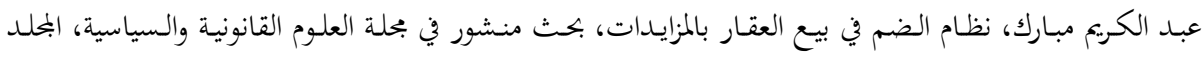

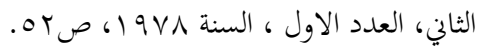

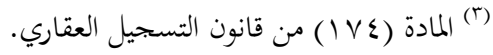

$$
\begin{aligned}
& \text { () هند فالم محمود العلاف، مصدر سابق. }
\end{aligned}
$$

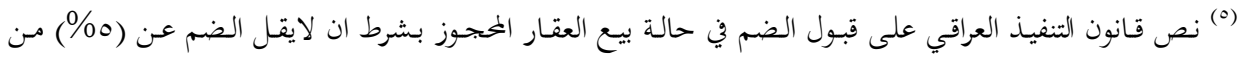

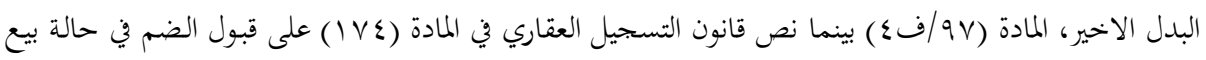

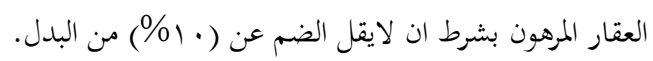




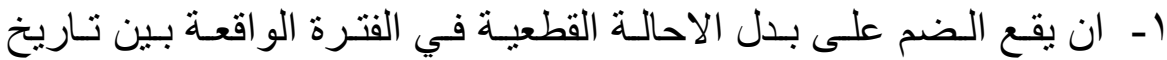

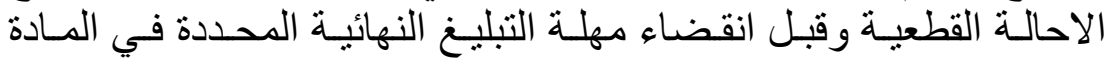

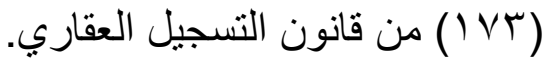

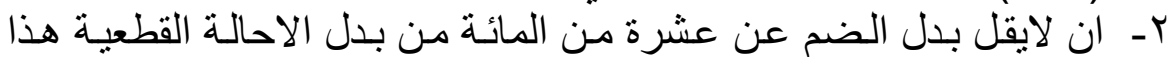

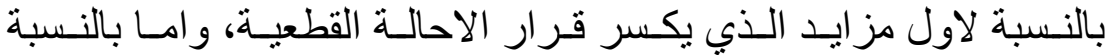

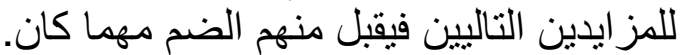

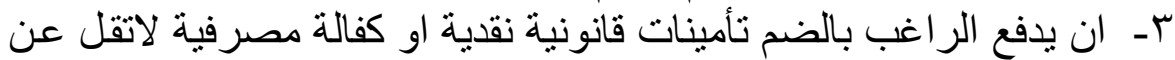

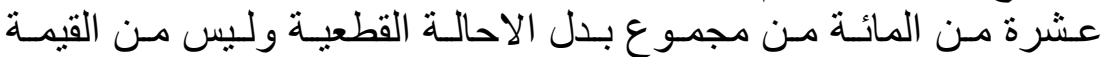

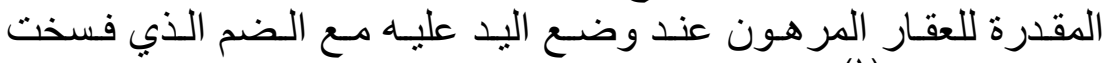

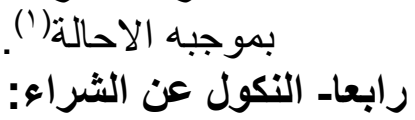

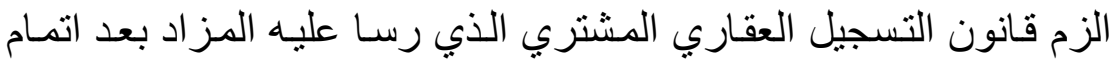

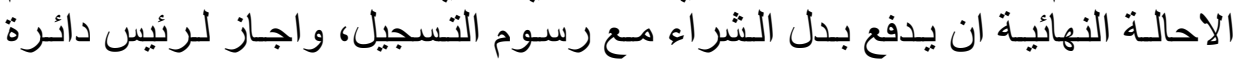

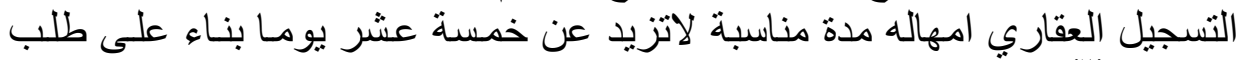

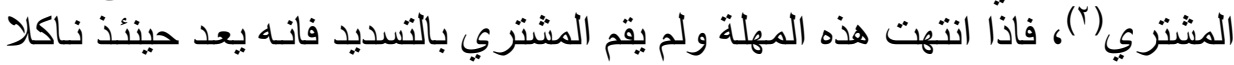

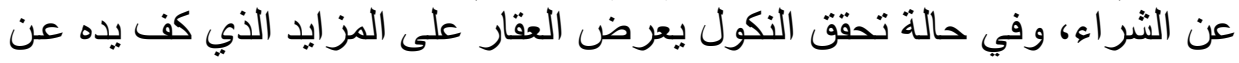

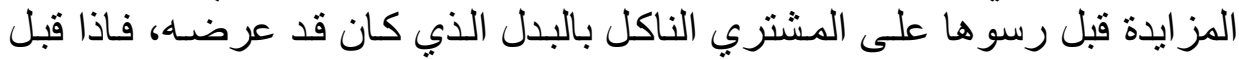

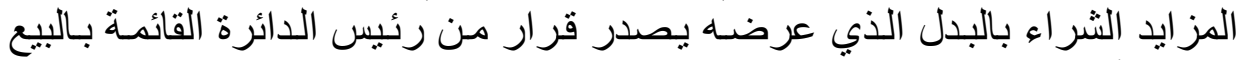

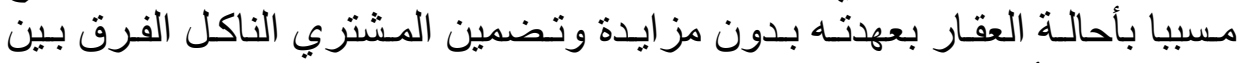

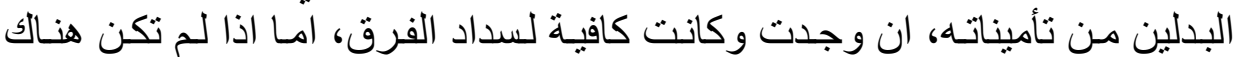

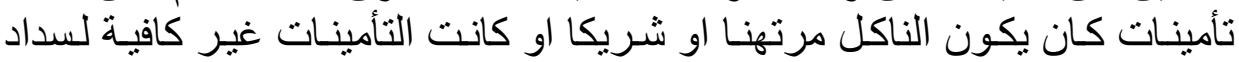

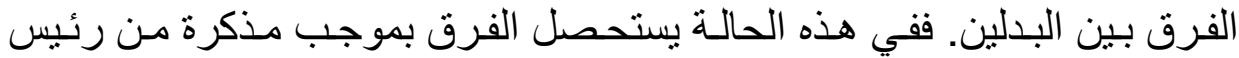

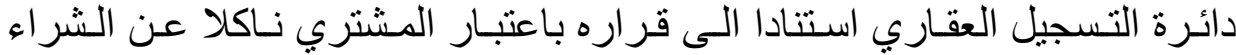

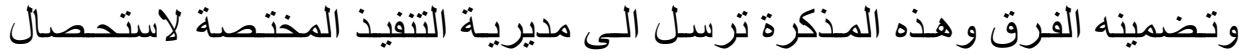

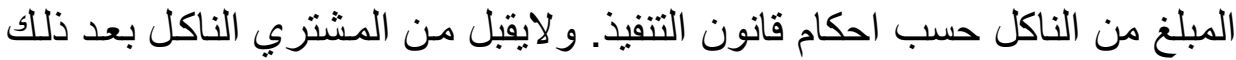

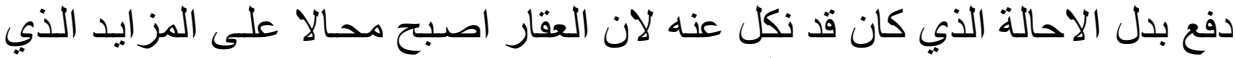

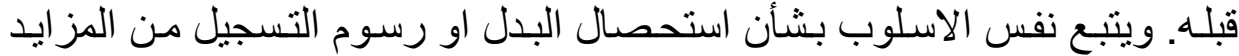

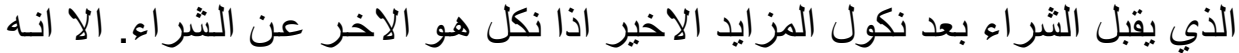

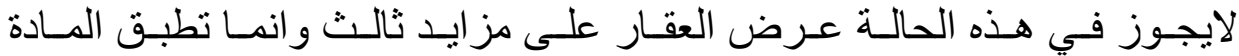

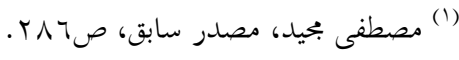

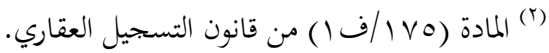




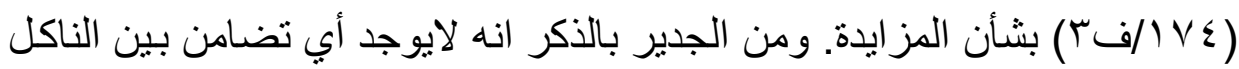

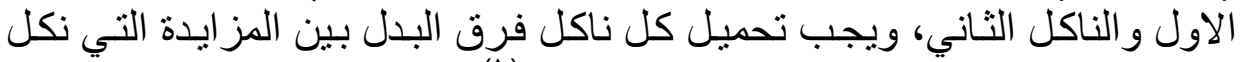

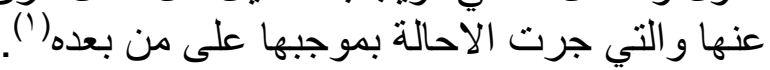

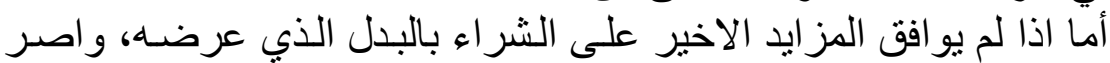

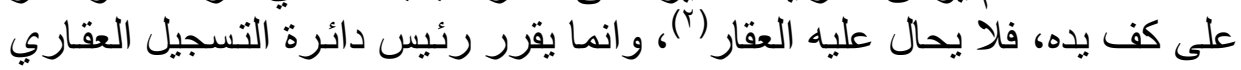

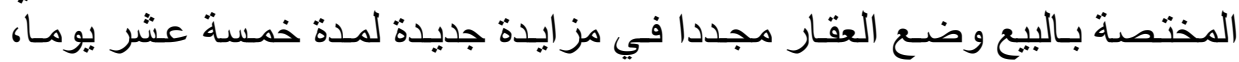

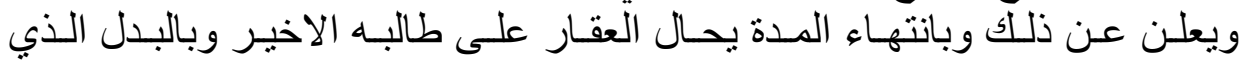

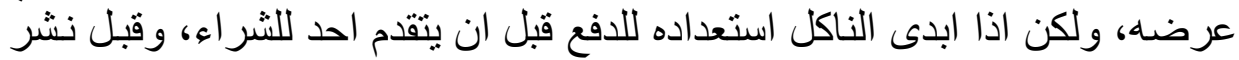

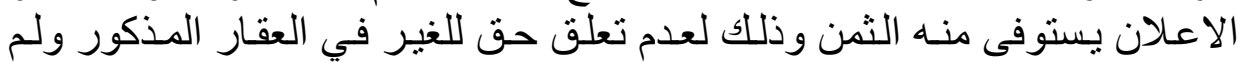

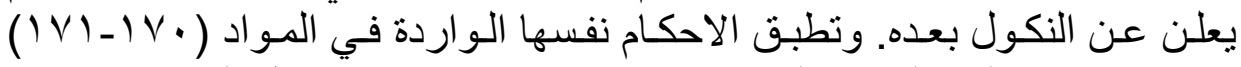

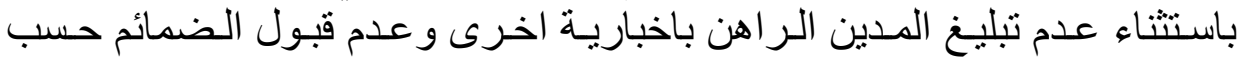

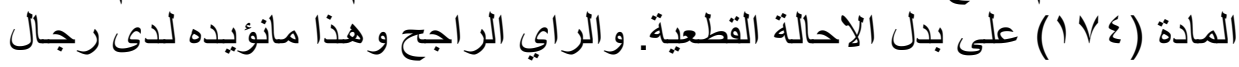

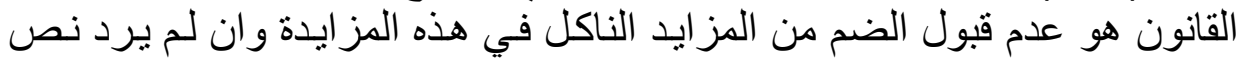

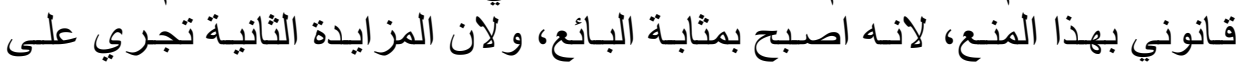

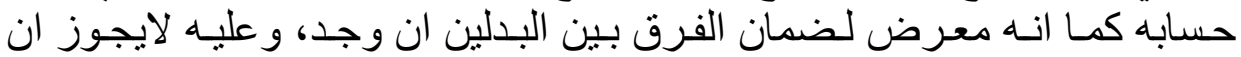

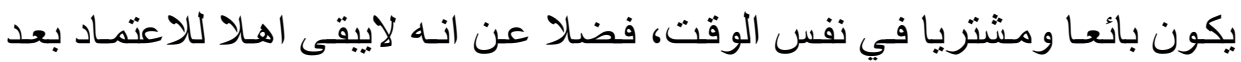

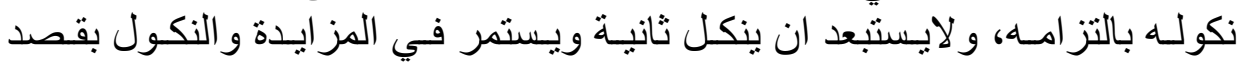

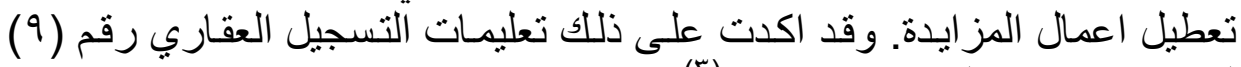

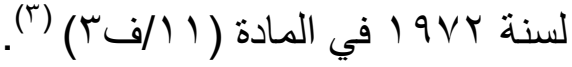
ونتيجة المز ايدة الجديدة، فاما ان تجري المز اليدان اليدة ببدل مساو لبدل الاحالة

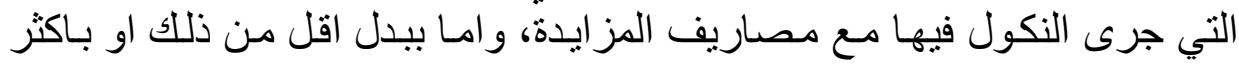

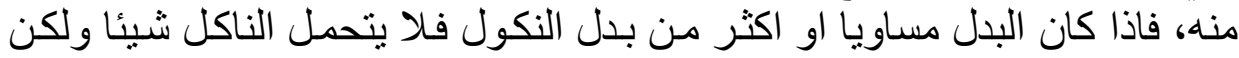

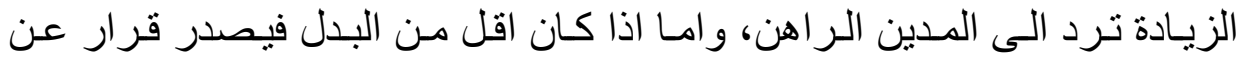

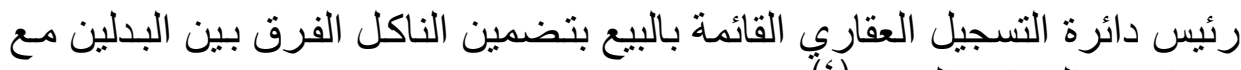
مصاريف المز ايدة الجديدة(")

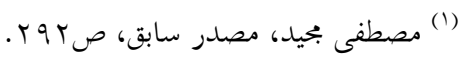

$$
\begin{aligned}
& \text { (T) }
\end{aligned}
$$

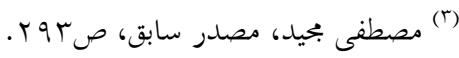

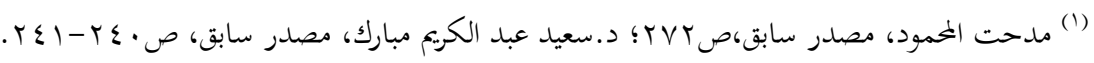


امـا اذا لم يحصل ر اغباً للشر اء بعد النكول فيتخذ رئيس دائرة التسجيل

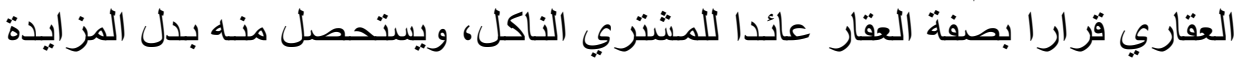

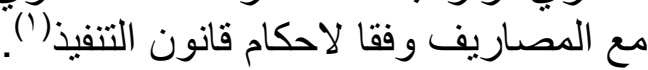

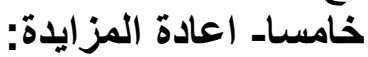

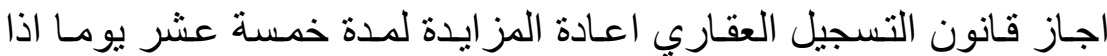

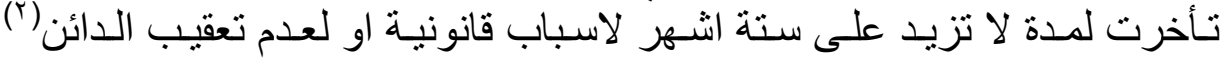

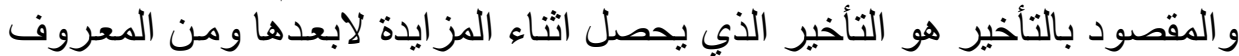

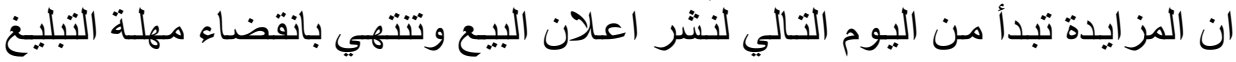

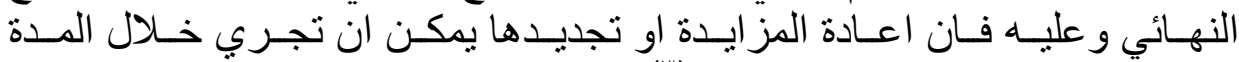

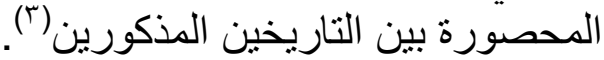

ومما تجدر الاشارة اليه ان اجر اءعات المز ايدة كثثيرة وتستغرق وقتاطيا طويلا

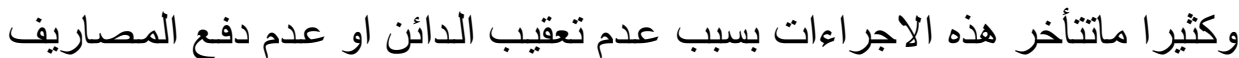

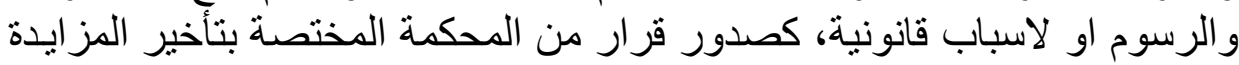

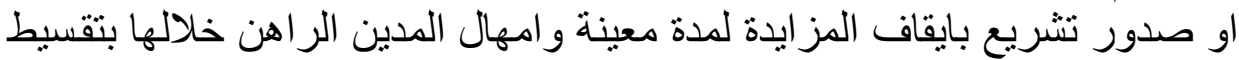

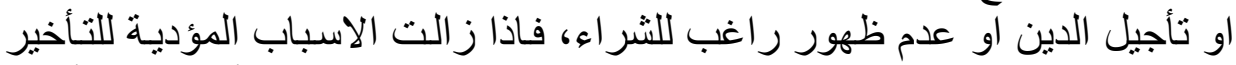

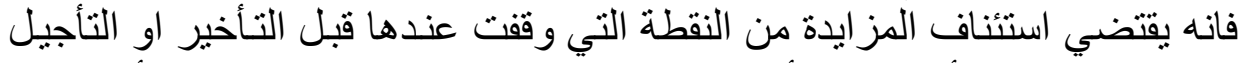

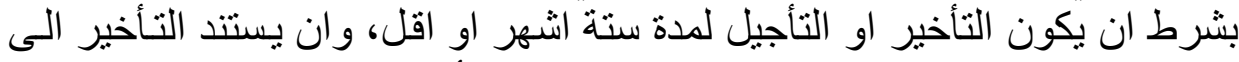

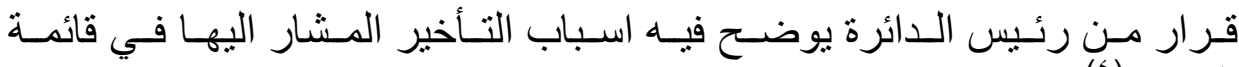

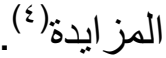

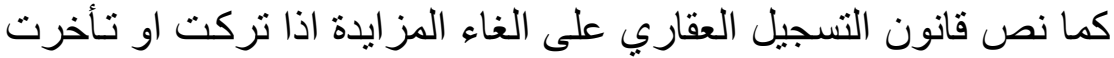

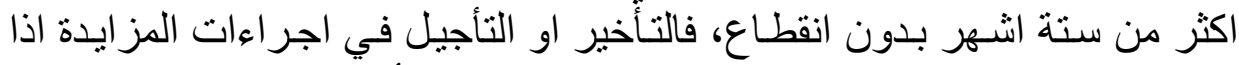

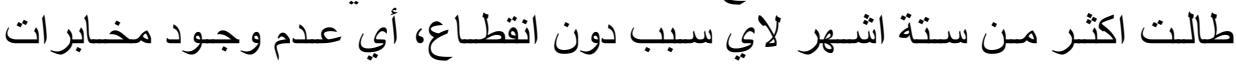

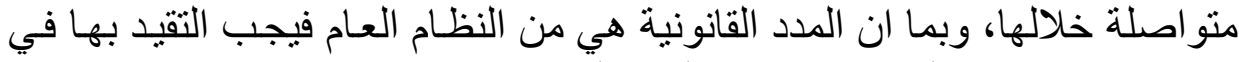

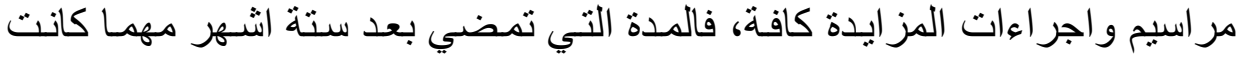
تجعل المز ايدة ملغاة لانها من المدد الحتمية، وتحسب التهب المدد المحددة بالشهور من كن

$$
\begin{aligned}
& \text { (r) المادة (V0/ V0) ) من قانون التسجيل العقاري. }
\end{aligned}
$$

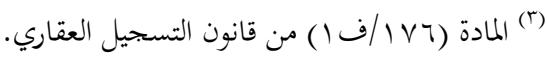

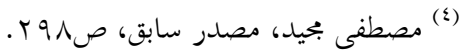

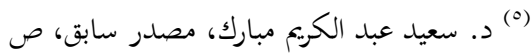


يـوم أبتـائها الـى اليـوم الـذي يقابلـه مـن الشهور التاليـة وليس علىى اسـاس ايـام الثهور (1)

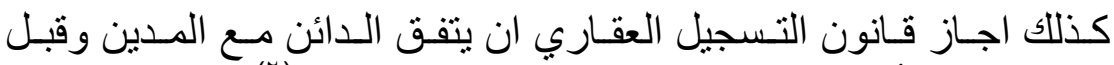
الاحالة القطعية على تأجيل المز ايدة لمدة لاتزيد على ستة اشهر (r).

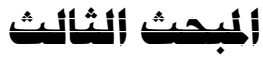

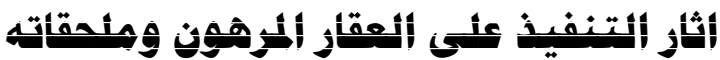

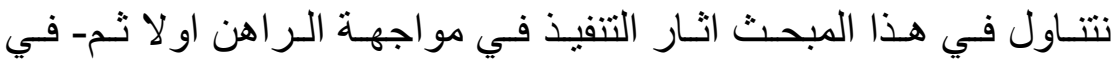
مواجهة الدائن في مطلبين مستقلين.

\section{jexil thit}

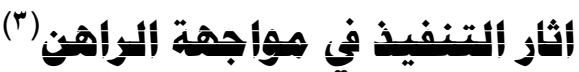

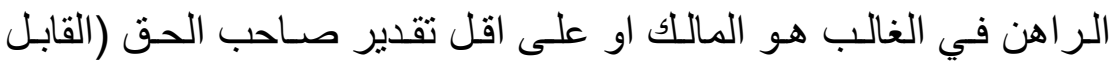

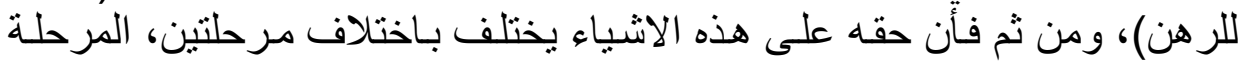

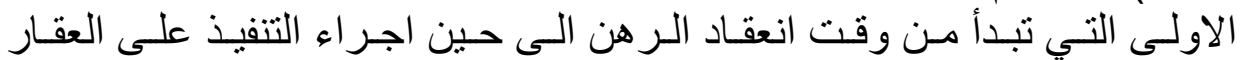

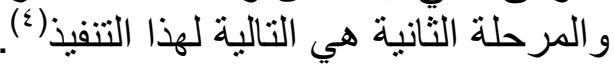

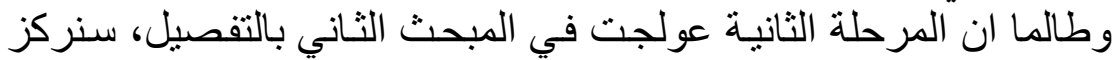

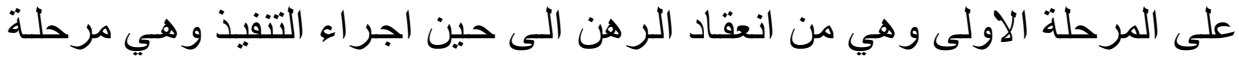

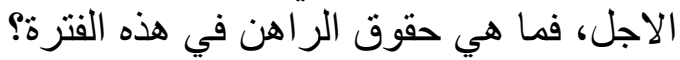

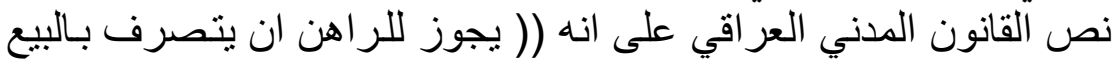

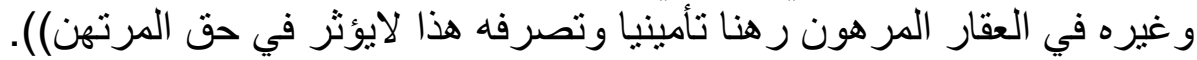

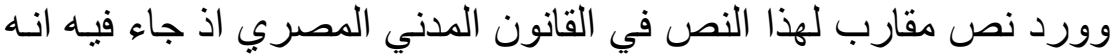

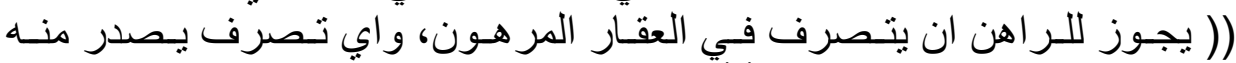

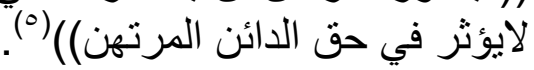

$$
\begin{aligned}
& \text { (1) (1) (لمادة (1 1 1) من قانون التسجيل العقاري. }
\end{aligned}
$$

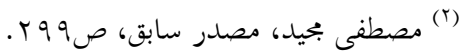

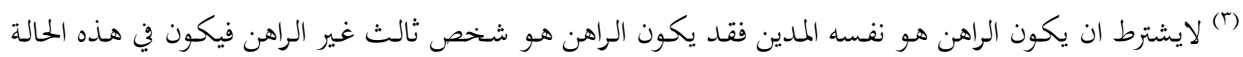

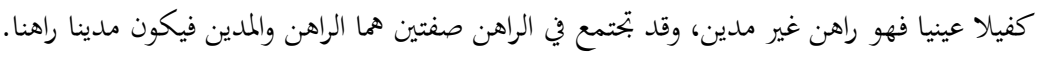

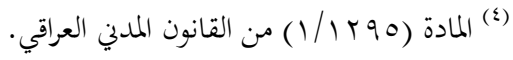

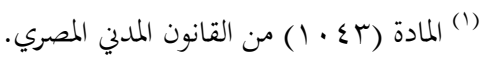


معنى هذه النصوص ان تصر فات الر اهن صـحيحة ونافذة تجـاه الـدائن

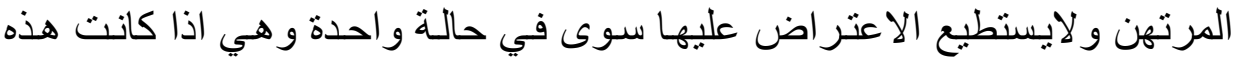

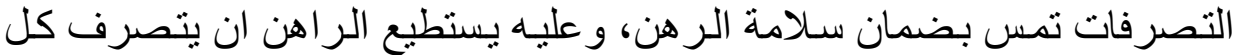

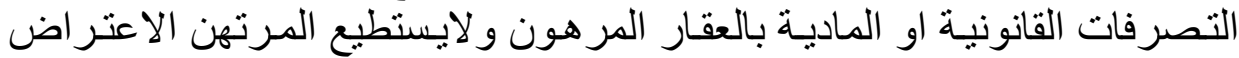

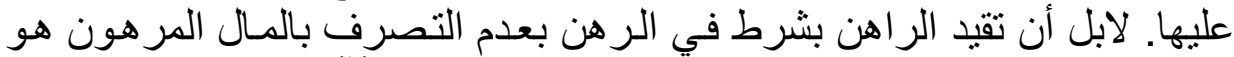

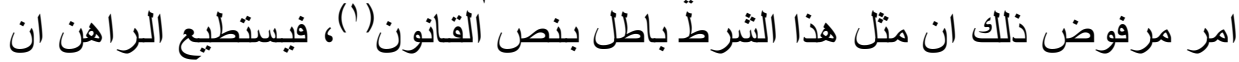

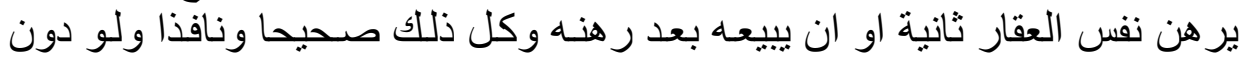

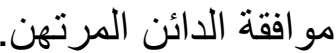

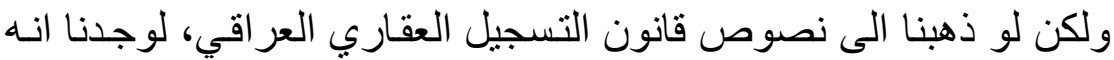

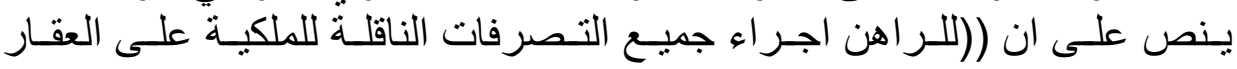

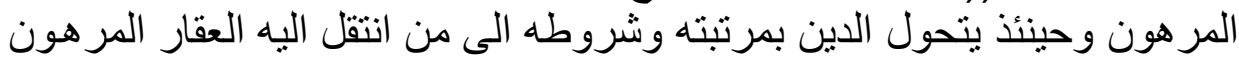

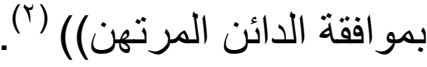

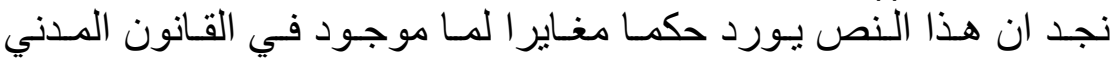

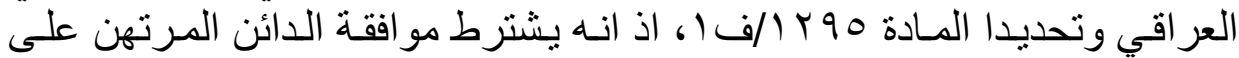

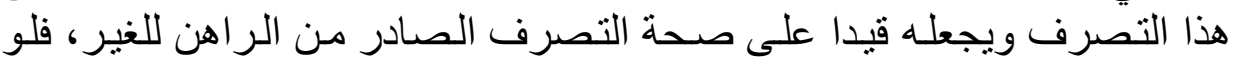

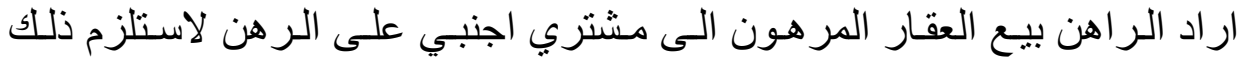

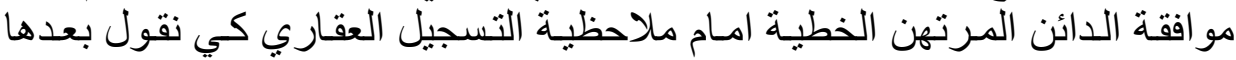

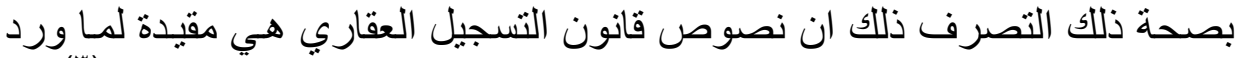

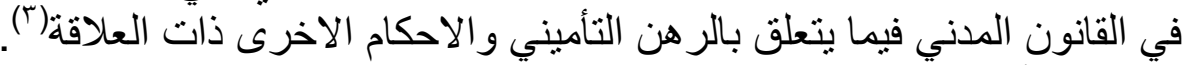

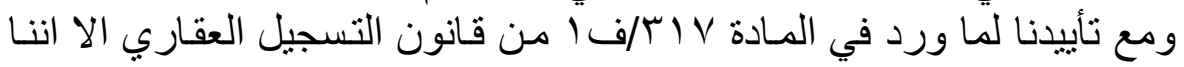

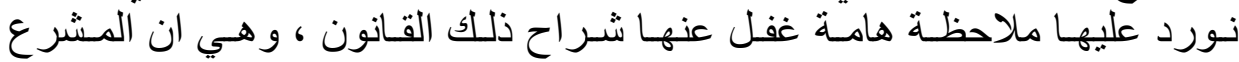

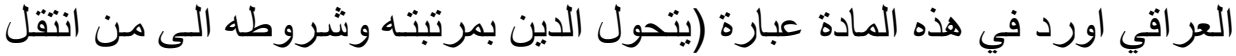

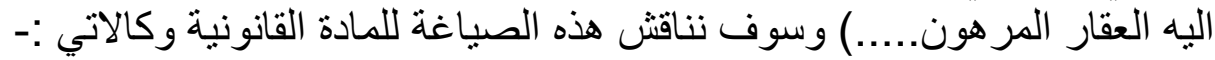

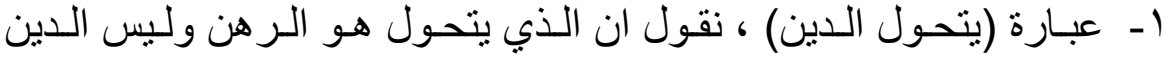

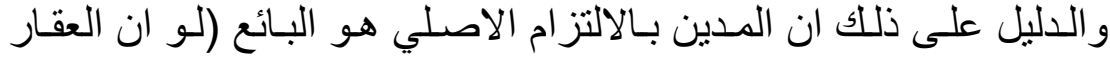

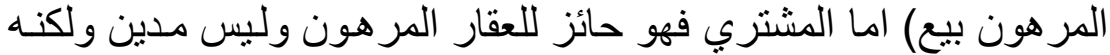

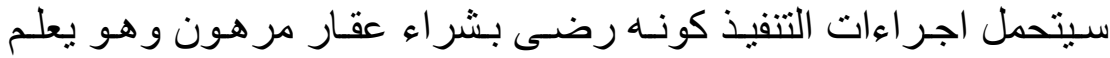

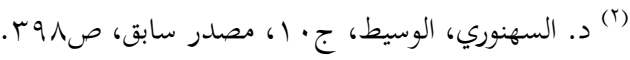

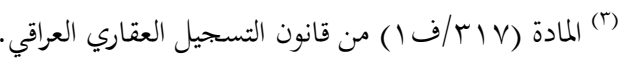

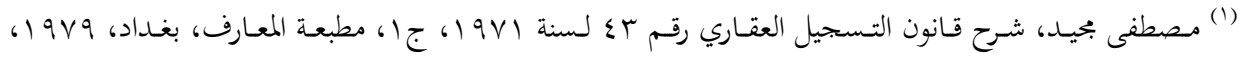


حتمـا انـه مر هون بقرينـة قانونيـة قاطعة لا تقبـل اثبـات العكس طالمـا انتـا

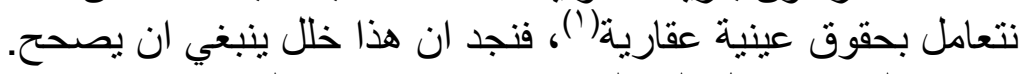

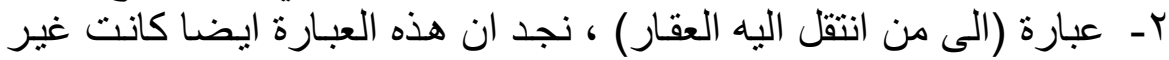

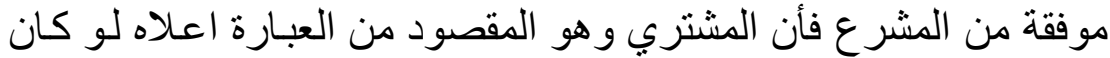

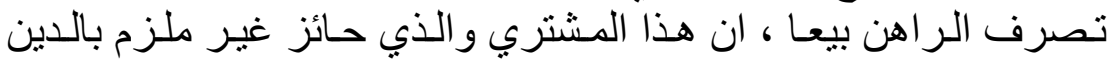

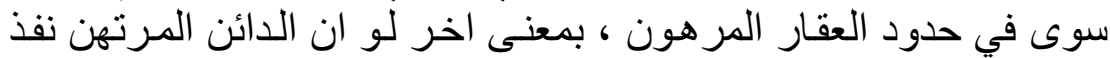

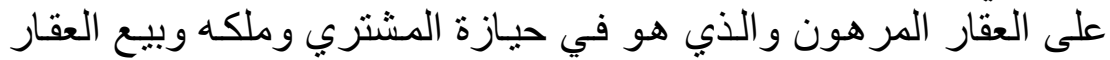

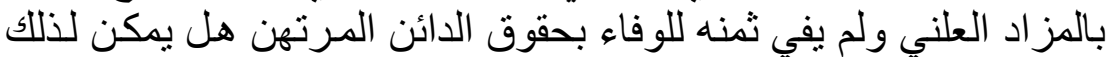

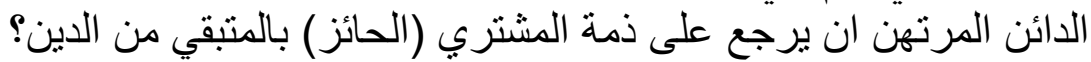

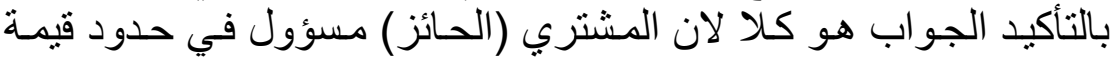

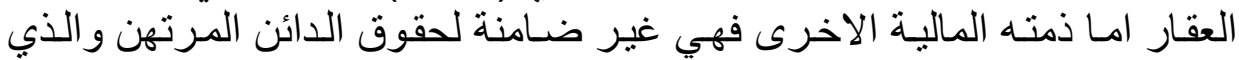

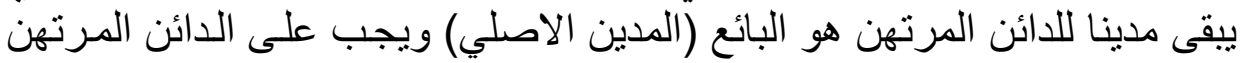

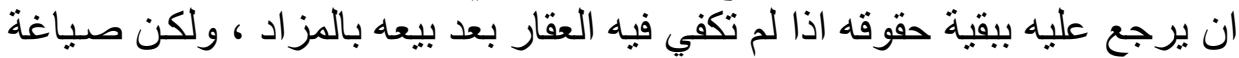

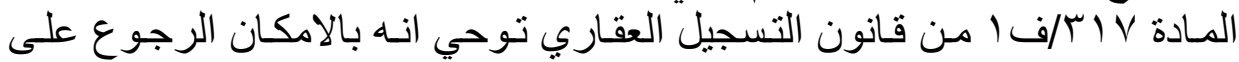

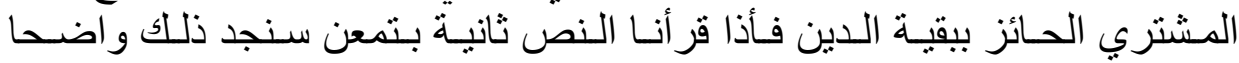

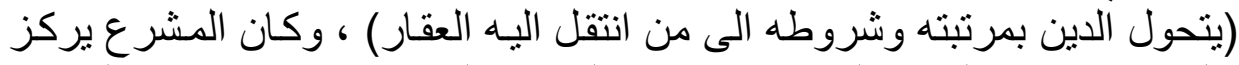

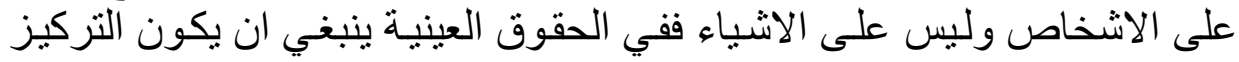

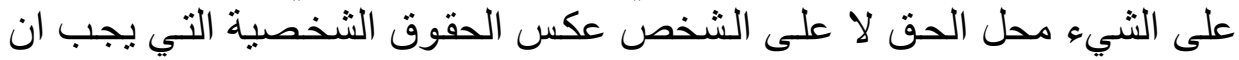

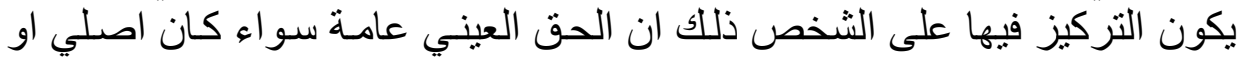

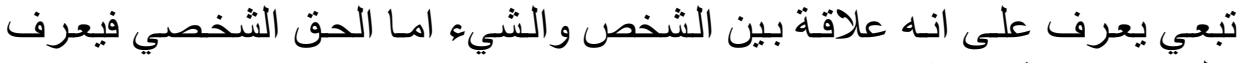
على انه علاقة بين شخصين.

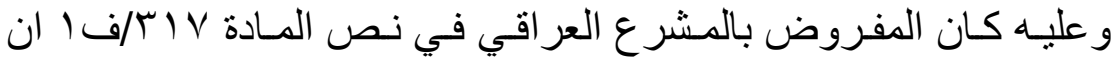

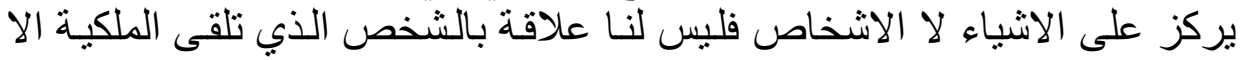
في حدود ضيقة.

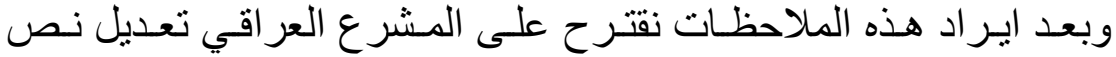

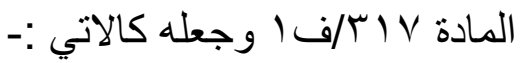

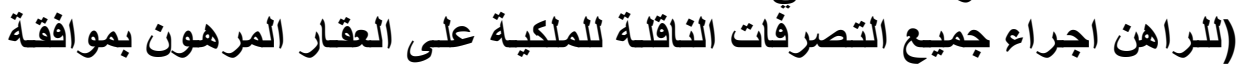

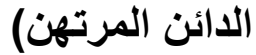

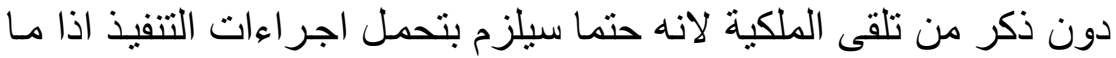
وصلنا الى هذه المرحلة وهو في الوقت نفسه سيكون غير ملزم بتحمل اكثر من لن انه 
قيمـة العقـار لـو بيـع بـالمز اد العلنـي ، امـا الـص الـسابق فكـان يـوحي بمثنل هـذا

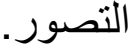

\section{|itifi}

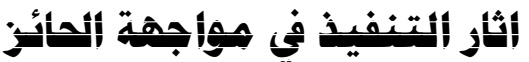

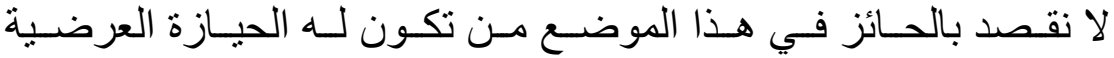

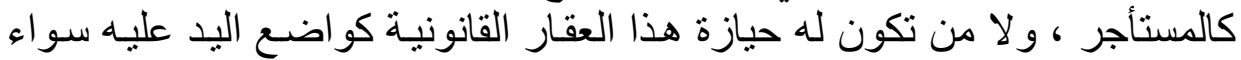

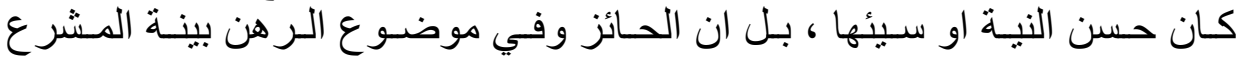

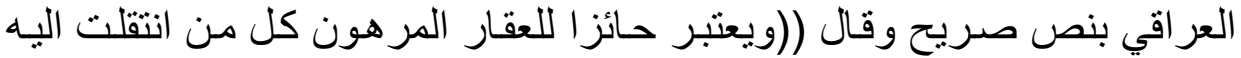

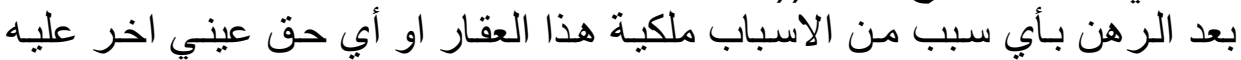

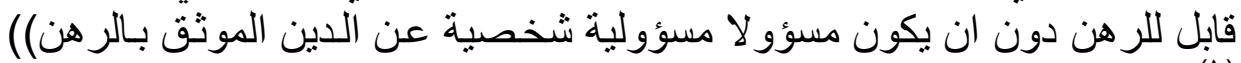

اذن الحائز هو من تتو افر فيه شروط ثلاتثة او لا يجب ان يتلقى الملكيـة او

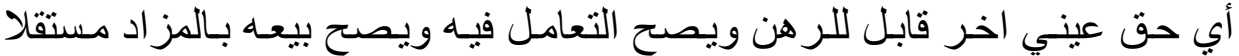

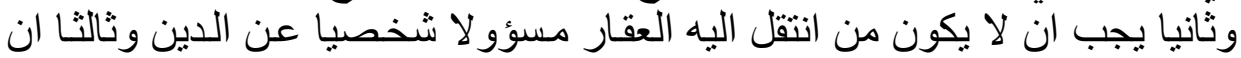

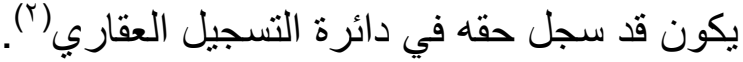

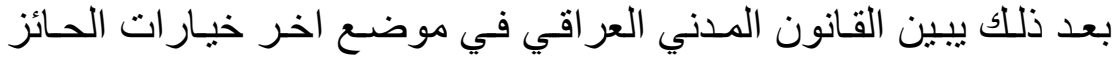

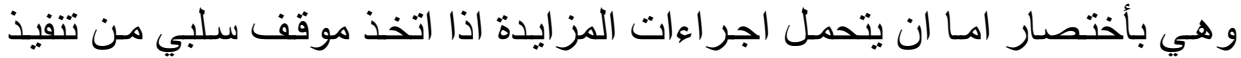

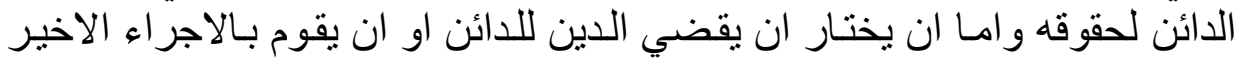

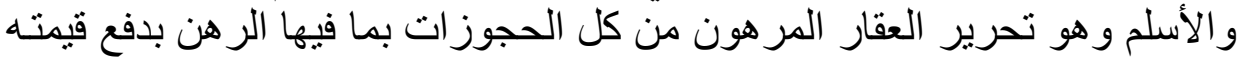

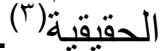

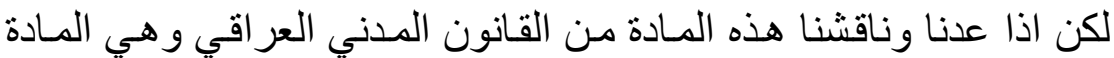

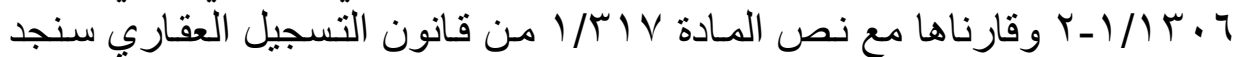

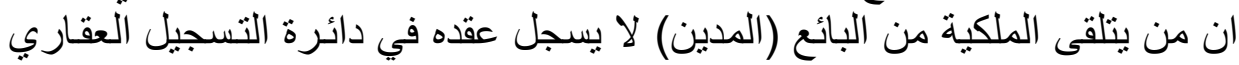

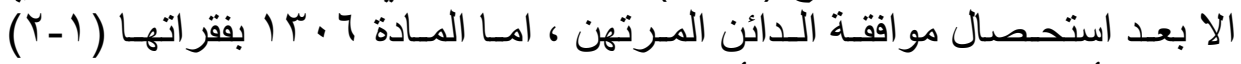

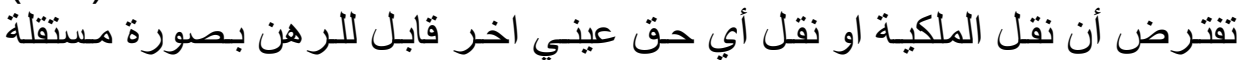

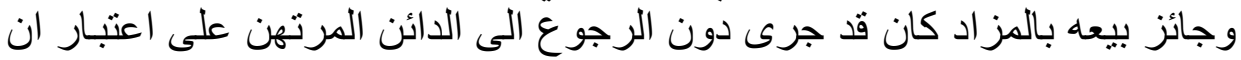

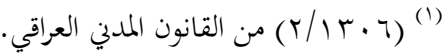

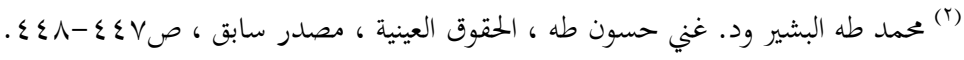

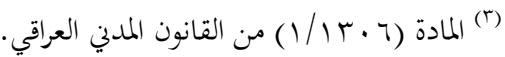




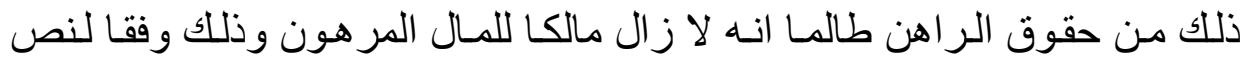

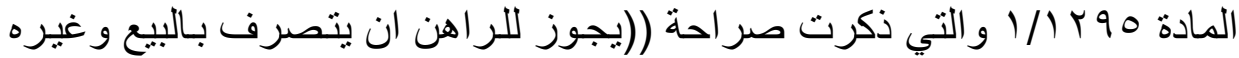

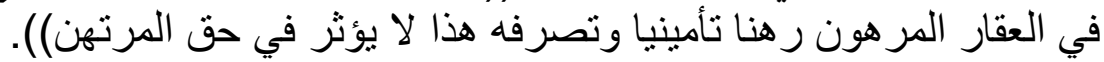

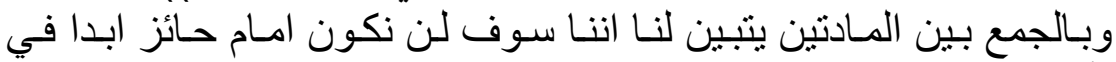

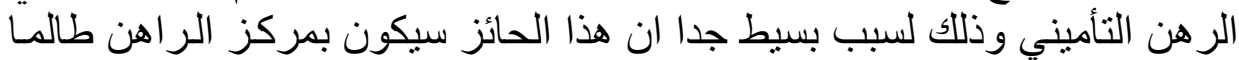

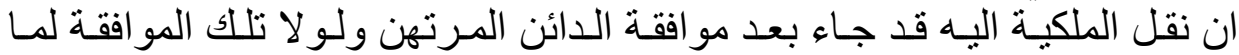

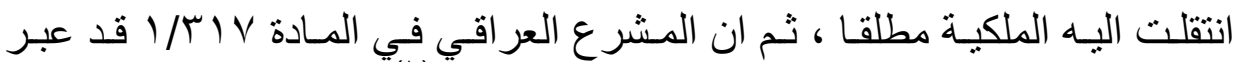

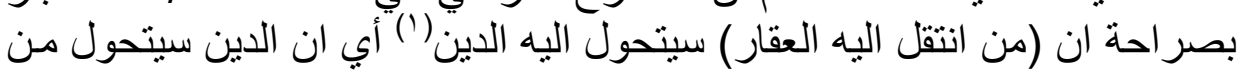

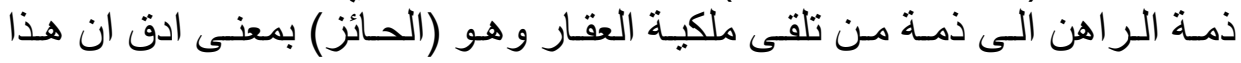

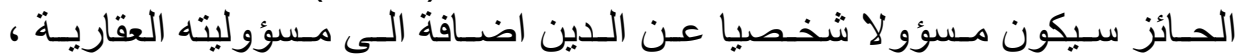

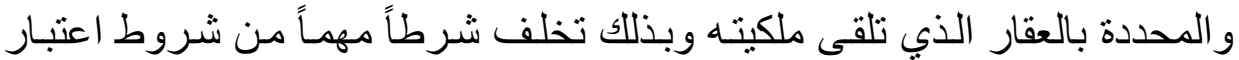

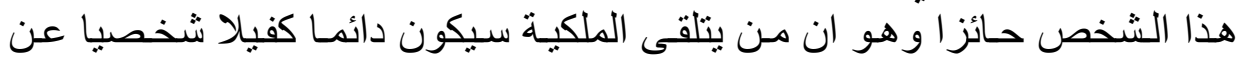

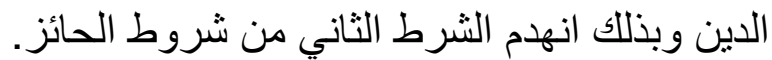

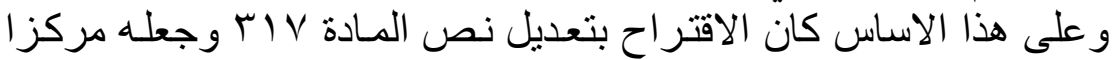

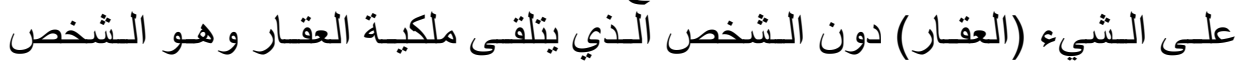

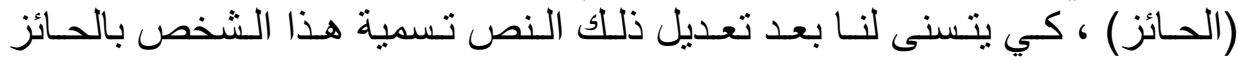

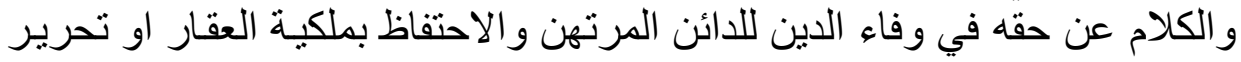

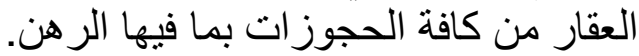

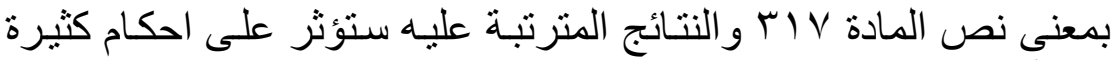

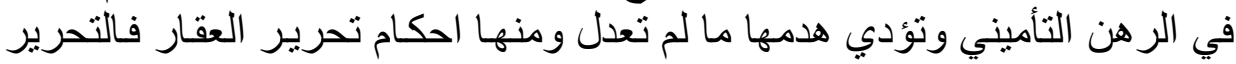

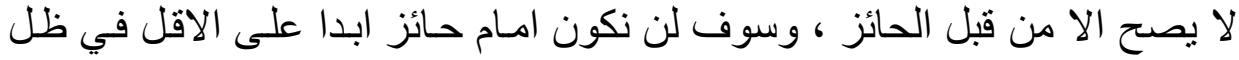

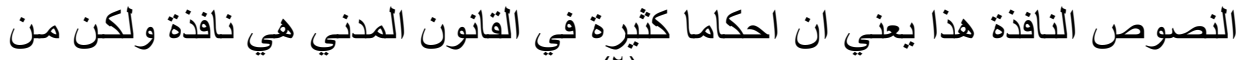

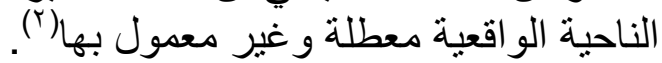

(1) (1) ولو اننا انقدنا هذا النص في صفحات سابقة.

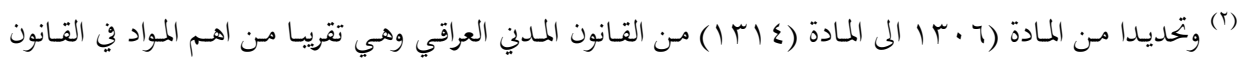

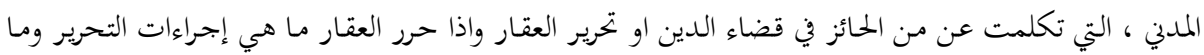

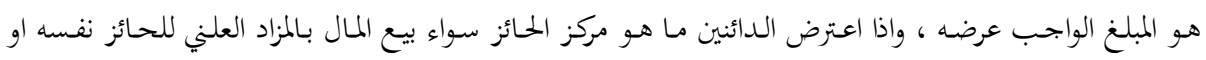


بعد هذه الدر اسة نتوصل الى عدة نتائج اهمها :-

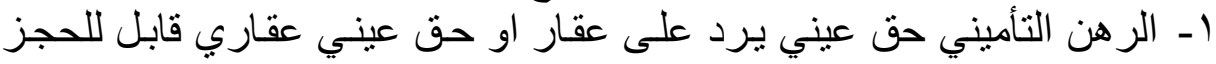
و البيع بالمز اد بصورة مستقلة.

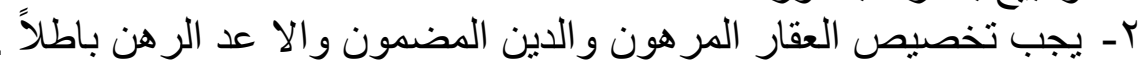

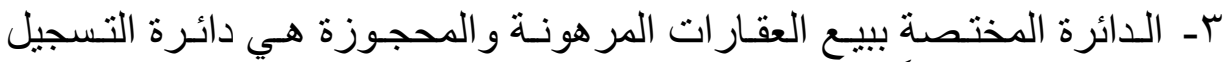

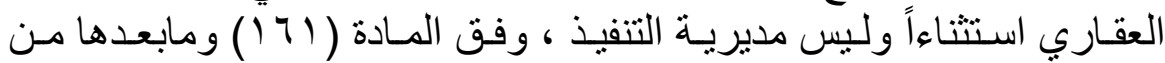

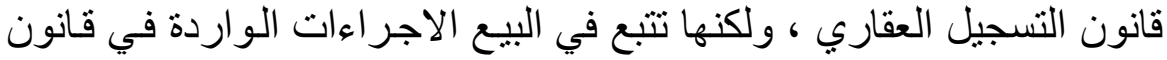

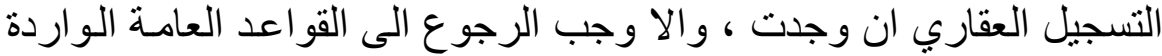

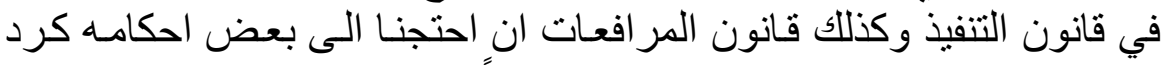

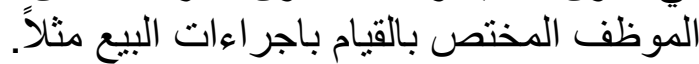

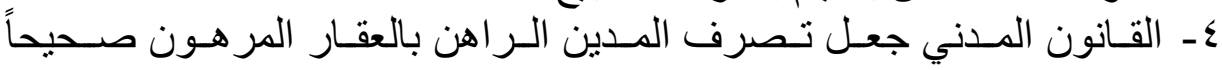

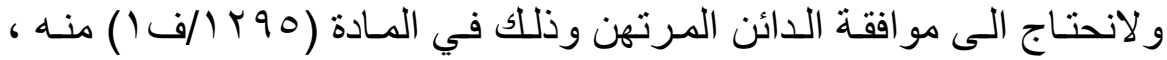

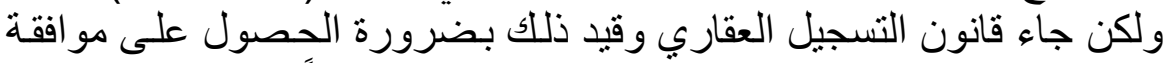

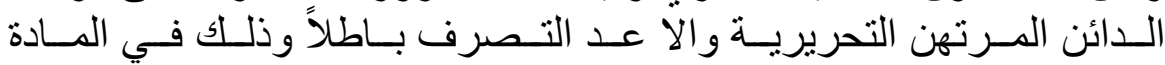

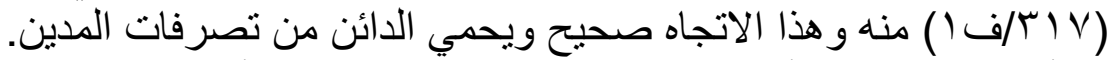

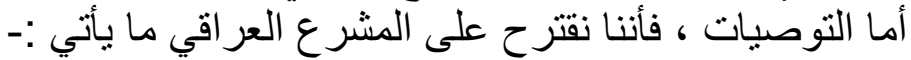

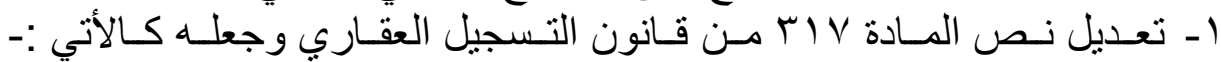

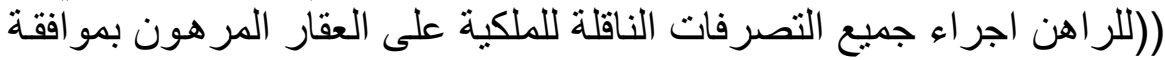

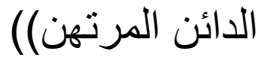

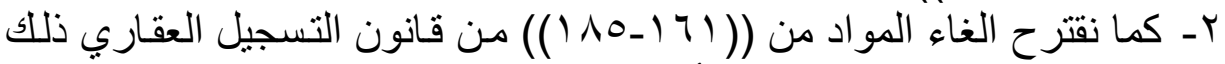

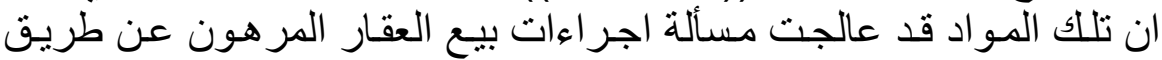

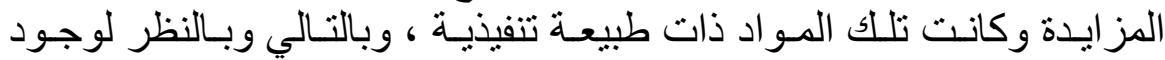

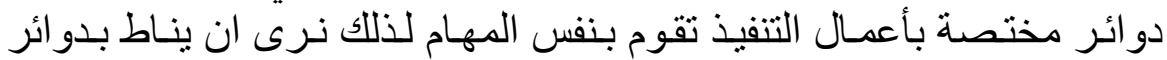

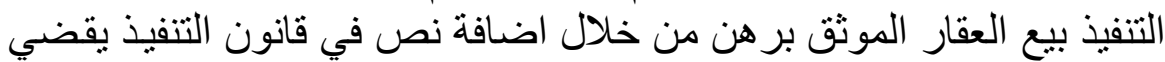

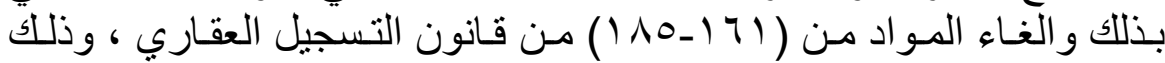

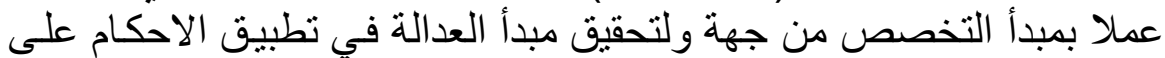

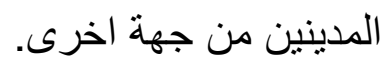

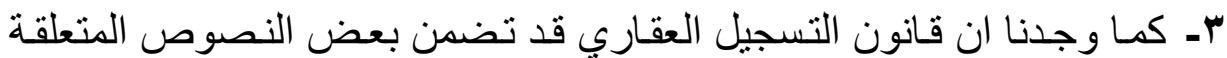

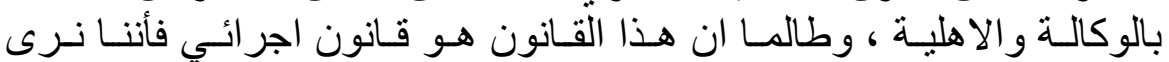


ضرورة استبعاد احكام الاهلية و الوكالـة منهـه وترك معالجنهـا للقانون المدني وقانون رعاية القاصرين لأنها القوانين المعنية بتلك المكام المسائل.

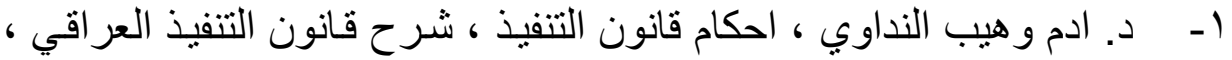

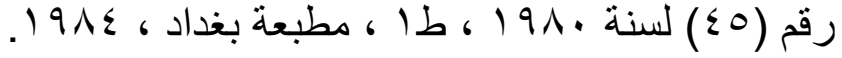

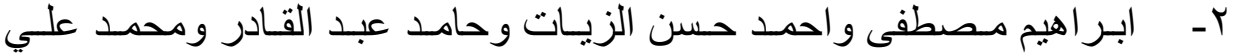

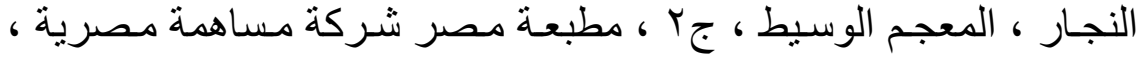

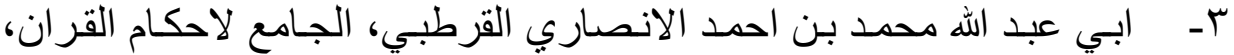

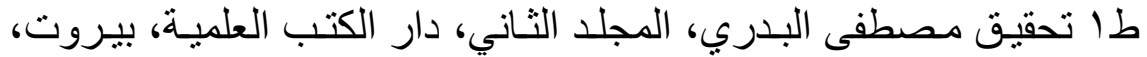

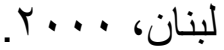

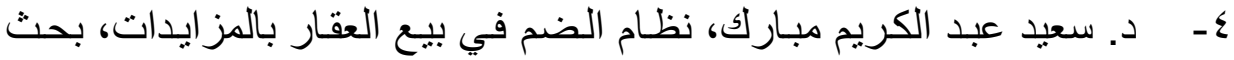

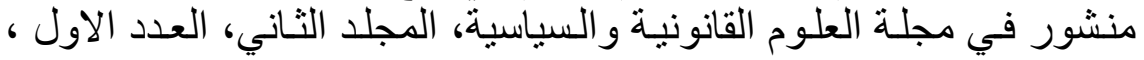

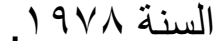

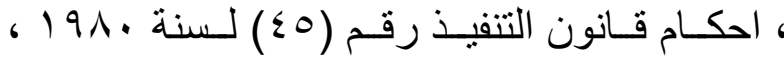

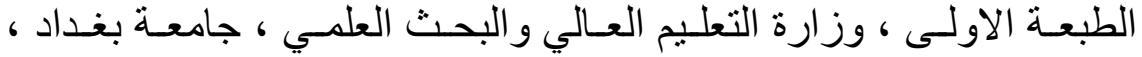
.1919

7ـ عـامر خطـاب عمـر، بيـع العقار عـن طريـق المزايـدة ، مطبعـة الزهـر اء،

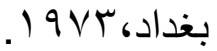

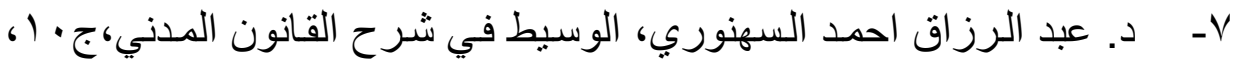

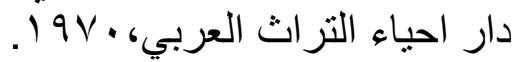

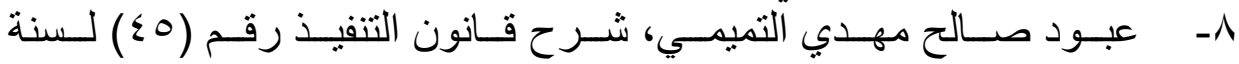

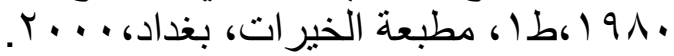

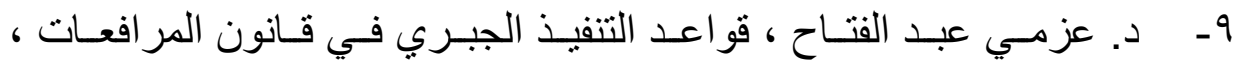

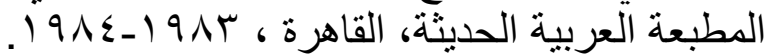

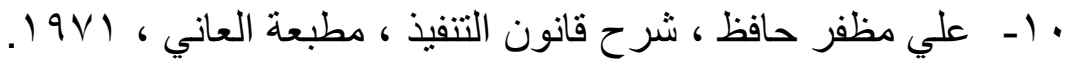

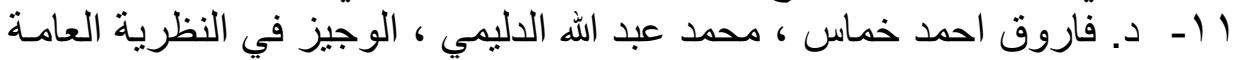

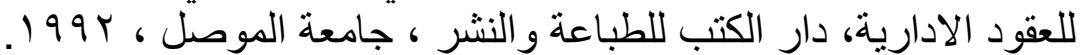




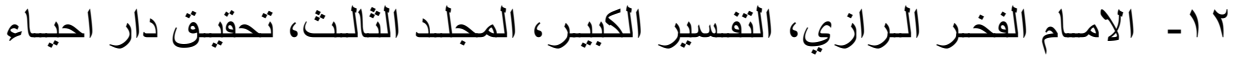

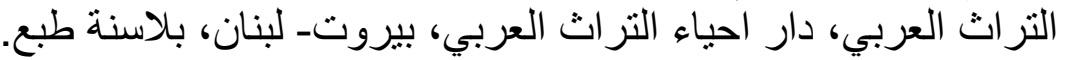

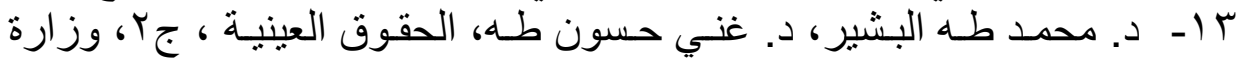

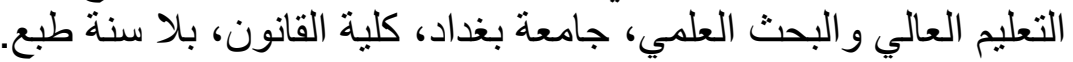

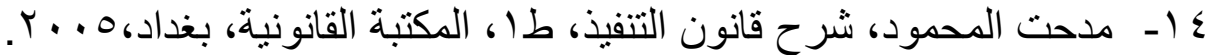

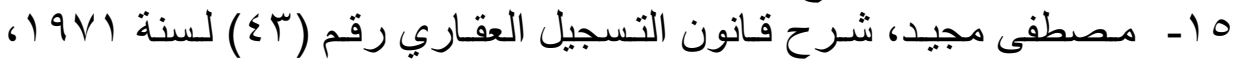

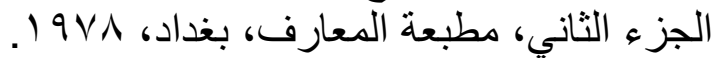

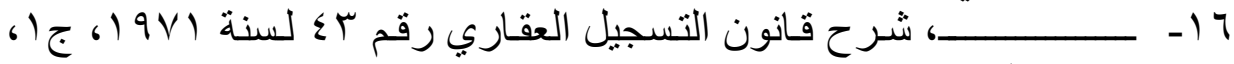

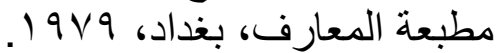
IV

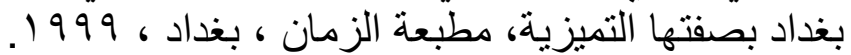

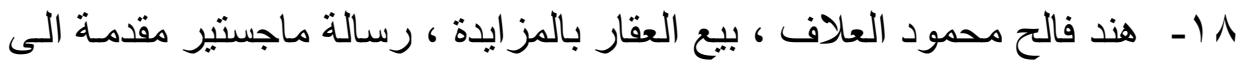

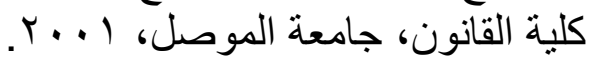
ثانيا : القوانين والتعليمات : التون جامعة التون

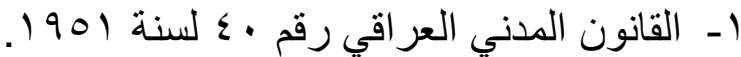

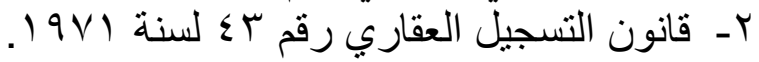

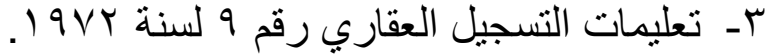

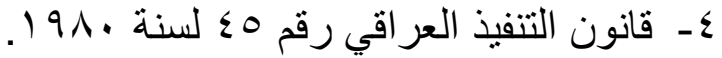

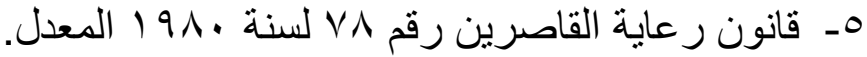

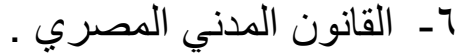
Vـ المذكرة الإيضناحية للقانون المدني المصري المدي ، جل ، دون مكان وسنة طبع. 